U.S. DEPARTMENT OF THE INTERIOR

U.S. GEOLOGICAL SURVEY

\title{
Geologic, Hydrologic, and Chemical Data from the C Aquifer near Leupp, Arizona
}

Scientific Investigations Report 2005-5280

Prepared in cooperation with the BUREAU OF RECLAMATION

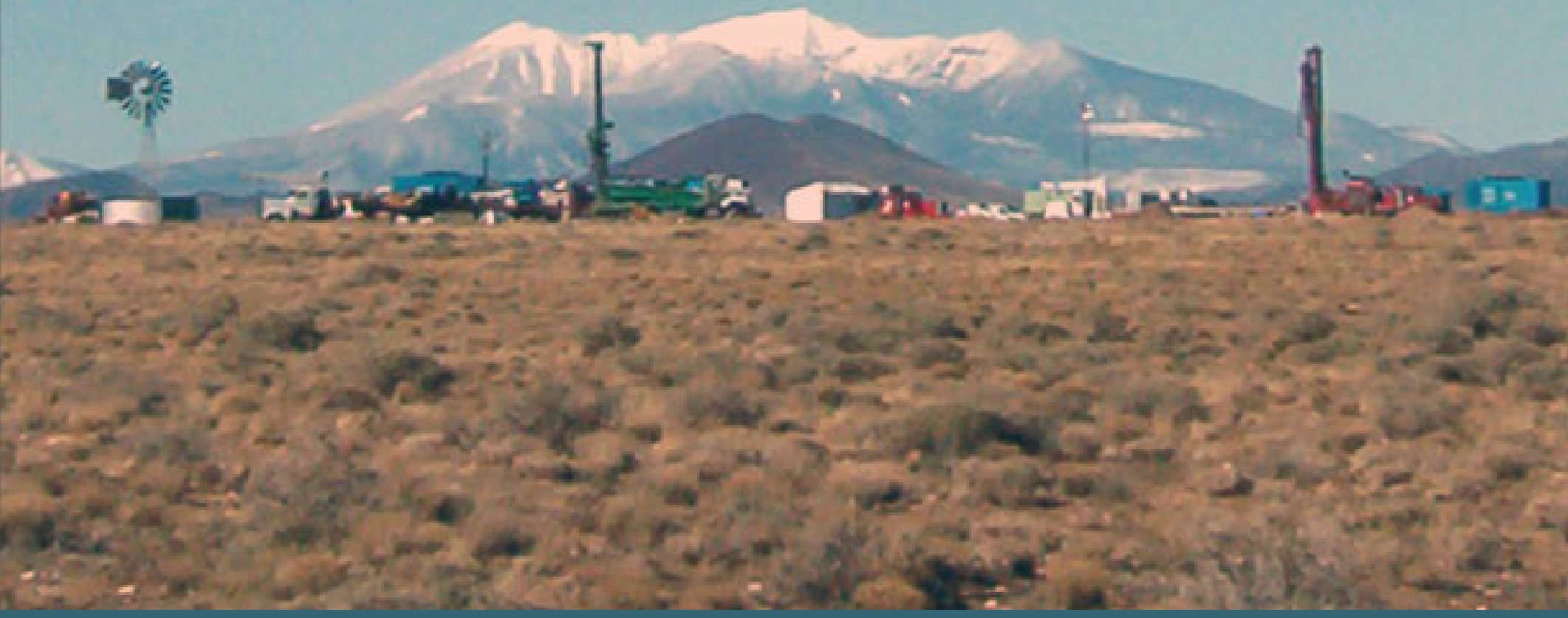




\section{Geologic, Hydrologic, and Chemical Data from the C Aquifer near Leupp, Arizona}

By J.P. Hoffmann, D.J. Bills, J.V. Phillips, and K.J. Halford

Prepared in cooperation with the Bureau of Reclamation

Scientific Investigations Report 2005-5280 


\section{U.S. Department of the Interior \\ Gale A. Norton, Secretary}

\section{U.S. Geological Survey \\ P. Patrick Leahy, Acting Director}

\section{U.S. Geological Survey, Reston, Virginia: 2006}

For product and ordering information:

World Wide Web: http://www.usgs.gov/pubprod

Telephone: 1-888-ASK-USGS

For more information on the USGS - the Federal source for science about the Earth, its natural and living resources, natural hazards, and the environment:

World Wide Web: http://www.usgs.gov

Telephone: 1-888-ASK-USGS

Any use of trade, product, or firm names is for descriptive purposes only and does not imply endorsement by the U.S. Government.

Suggested citation:

Hoffmann, J.P., Bills, D.J., Phillips, J.V., and Halford, K.J., 2006, Geologic, hydrologic, and chemical data from the C aquifer near Leupp, Arizona: U.S. Geological Survey Scientific Investigations Report 2005-5280, 42 p. 


\section{Contents}

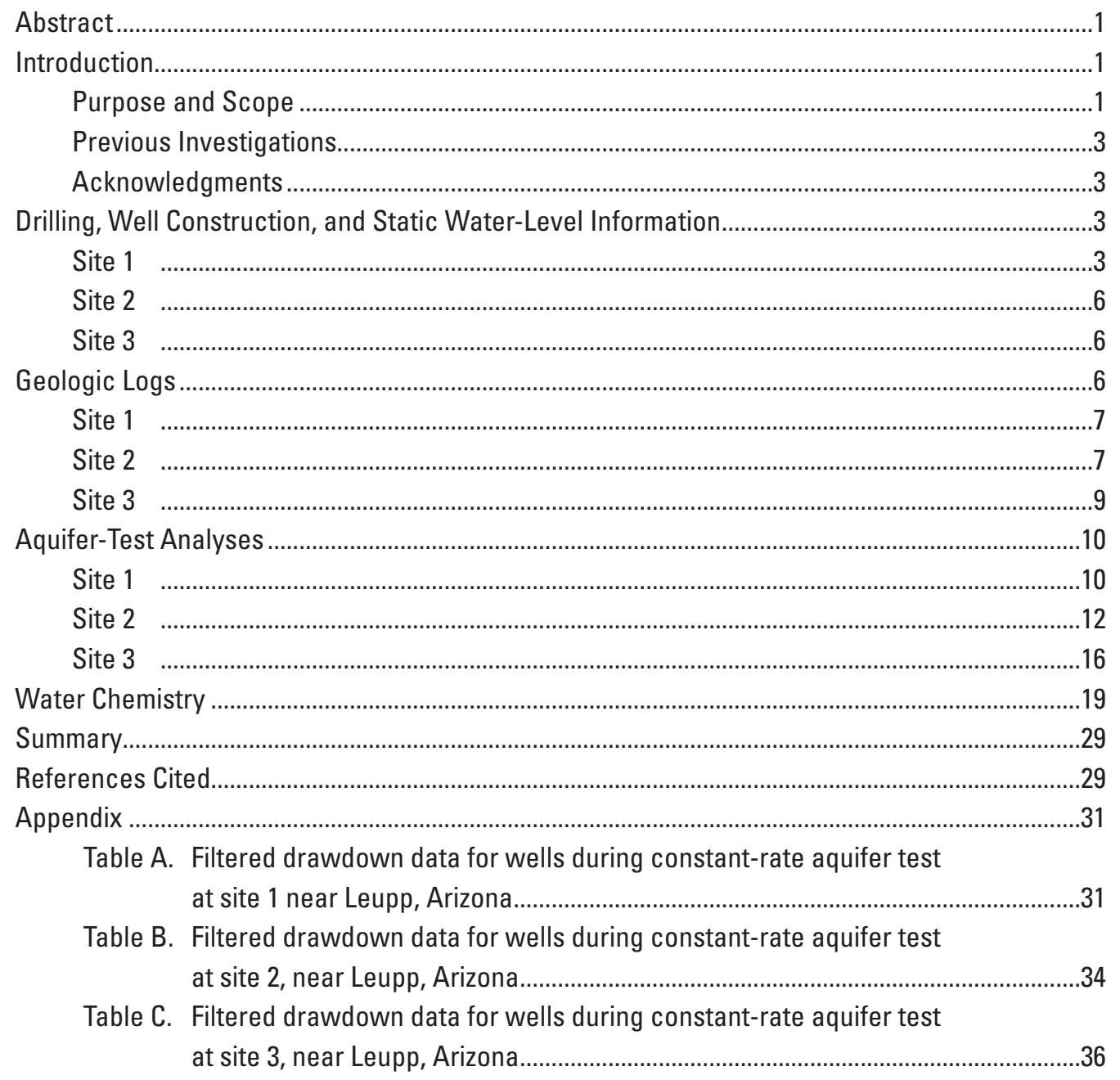




\section{Figures}

1. Map showing approximate extent of the $C$ aquifer and location of the study area, northeastern Arizona.

2. Map showing location of drill sites, test wells, and windmill wells near Leupp, Arizona

3. Graph showing filtered water-level drawdown and recovery at site 1 during aquifer test near Leupp, Arizona

4. Graph showing simulated and measured water-level drawdown in PW-1A, OW-1, and windmill well 5T-533 near Leupp, Arizona

5. Graph showing water-level drawdown during aquifer test at site 2 near Leupp, Arizona.

6. Graph showing straight-line methods to estimate transmissivity and storage coefficient at site 2 near Leupp, Arizona

A, Distance drawdown; $B$, Time drawdown

7. Graph showing simulated and measured water-level drawdown at site 2 near Leupp, Arizona. A, OW-2A (middle), OW-2, and PW-2B;

B, OW-2A (shallow), OW-2A (middle), PW-2A, and 5M-94

8. Graph showing water-level record at site 3 near Leupp, Arizona.

A, Depth to water; B, Water-level drawdown

9. Graph showing water-level record at site 3 for period prior to pumping and during pumping and recovery periods of aquifer tests, near Leupp, Arizona

\section{Tables}

1. Well locations and selected construction data for the wells at sites 1, 2 and 3, and the Sunshine well near Leupp, Arizona

2. Summary of geologic logs and available geophysical logs from test wells at site 1

3. Summary of geologic logs and available geophysical logs from test wells at site 2

4. Summary of geologic logs and available geophysical logs from test wells at site 3

5. Estimated hydraulic properties from numerical-model simulations at test-well sites 1, 2, and 3 near Leupp, Arizona.

6. Field parameters and chemical constituents of water collected from test wells at sites 1, 2, 3 and from the Sunshine well near Leupp, Arizona 


\section{Conversion Factors}

\begin{tabular}{|c|c|c|}
\hline Multiply & By & To obtain \\
\hline \multicolumn{3}{|c|}{ Length } \\
\hline inch (in) & 2.54 & centimeter $(\mathrm{cm})$ \\
\hline foot $(\mathrm{ft})$ & 0.3048 & meter $(\mathrm{m})$ \\
\hline mile (mi) & 1.609 & kilometer $(\mathrm{km})$ \\
\hline \multicolumn{3}{|c|}{ Area } \\
\hline acre & 4,047 & square meter $\left(\mathrm{m}^{2}\right)$ \\
\hline square foot $\left(\mathrm{ft}^{2}\right)$ & 0.09290 & square meter $\left(\mathrm{m}^{2}\right)$ \\
\hline square mile $\left(\mathrm{mi}^{2}\right)$ & 2.590 & square kilometer $\left(\mathrm{km}^{2}\right)$ \\
\hline \multicolumn{3}{|c|}{ Volume } \\
\hline gallon (gal) & 0.003785 & cubic meter $\left(\mathrm{m}^{3}\right)$ \\
\hline cubic foot $\left(\mathrm{ft}^{3}\right)$ & 0.02832 & cubic meter $\left(\mathrm{m}^{3}\right)$ \\
\hline acre-foot (acre-ft) & 1,233 & cubic meter $\left(\mathrm{m}^{3}\right)$ \\
\hline \multicolumn{3}{|c|}{ Flow rate } \\
\hline cubic foot per second $\left(\mathrm{ft}^{3} / \mathrm{s}\right)$ & 0.02832 & cubic meter per second $\left(\mathrm{m}^{3} / \mathrm{s}\right)$ \\
\hline gallon per minute (gal/min) & 0.06309 & liter per second $(\mathrm{L} / \mathrm{s})$ \\
\hline \multicolumn{3}{|c|}{ Specific capacity } \\
\hline $\begin{array}{l}\text { gallon per minute per foot } \\
(\mathrm{gal} / \mathrm{min}) / \mathrm{ft}\end{array}$ & 0.2070 & $\begin{array}{l}\text { liter per second per meter } \\
\qquad(\mathrm{L} / \mathrm{s}) / \mathrm{m}\end{array}$ \\
\hline \multicolumn{3}{|c|}{ Hydraulic conductivity } \\
\hline foot per day (ft/d) & 0.3048 & meter per day $(\mathrm{m} / \mathrm{d})$ \\
\hline \multicolumn{3}{|c|}{ Transmissivity* } \\
\hline foot squared per day $\left(\mathrm{ft}^{2} / \mathrm{d}\right)$ & 0.09290 & meter squared per day $\left(\mathrm{m}^{2} / \mathrm{d}\right)$ \\
\hline
\end{tabular}

Temperature in degrees Celsius $\left({ }^{\circ} \mathrm{C}\right)$ may be converted to degrees Fahrenheit $\left({ }^{\circ} \mathrm{F}\right)$ as follows:

$$
{ }^{\circ} \mathrm{F}=\left(1.8 \mathrm{x}^{\circ} \mathrm{C}\right)+32
$$

Vertical coordinate information is referenced to the North American Vertical Datum of 1988 (NAVD 88).

Horizontal coordinate information is referenced to the North American Datum of 1983 (NAD 83).

Altitude, as used in this report, refers to distance above the vertical datum.

*Transmissivity: The standard unit for transmissivity is cubic foot per day per square foot times foot of aquifer thickness $\left[\left(\mathrm{ft}^{3} / \mathrm{d}\right) / \mathrm{ft}^{2}\right] \mathrm{ft}$. In this report, the mathematically reduced form, foot squared per day $\left(\mathrm{ft}^{2} / \mathrm{d}\right)$, is used for convenience.

Specific conductance is given in microsiemens per centimeter at 25 degrees Celsius $\left(\mu \mathrm{S} / \mathrm{cm}\right.$ at $25^{\circ} \mathrm{C}$ ).

Concentrations of chemical constituents in water are given either in milligrams per liter (mg/L) or micrograms per liter ( $\mu \mathrm{g} / \mathrm{L})$. 


\title{
Geologic, Hydrologic, and Chemical Data from the C Aquifer near Leupp, Arizona
}

\author{
By J.P. Hoffmann, D.J. Bills, J.V. Phillips, and K. J. Halford
}

\section{Abstract}

As the most productive aquifer in northern Arizona, the $\mathrm{C}$ aquifer provides industry, land owners, businesses, and municipalities with a dependable supply of water. Because additional development is proposed, the U.S. Geological Survey, in cooperation with the Bureau of Reclamation, conducted an investigation of the $\mathrm{C}$ aquifer that included the collection of geologic, hydrologic, and water-chemistry data near Leupp, Arizona. The investigation included a program to drill test wells at three sites and use the wells to collect geologic and geophysical logs, collect and analyze aquifer-test data, and collect water samples for water-chemistry analyses. Rock units penetrated during drilling were, in descending order, the Moenkopi, Kaibab, and Toroweap Formations, the Coconino Sandstone, the Schnebly Hill Formation, and the Upper Supai Formation. The water table generally was within the Coconino Sandstone and ranged from about 226 to 615 feet below land surface. Constant-rate aquifer tests were simulated by using numerical models to estimate aquifer properties. Estimated transmissivity of the $\mathrm{C}$ aquifer near Leupp, Arizona, ranges from about 5,400 to 7,000 feet squared per day. The Coconino Sandstone is the most conductive unit of the aquifer.

Water quality, determined from samples collected during the constant-rate aquifer tests, is generally good for intended uses. Field specific-conductance values ranged from 837 to 1,230 microsiemens per centimeter and correlate with concentrations of dissolved chloride and sodium. Concentrations of arsenic and other trace metals, as well as concentrations of nutrients, were low. Concentrations of sulfate exceeded the U.S. Environmental Protection Agency Secondary Maximum Contaminant Level of 250 milligrams per liter at all sites and were highest at site 1 (about 385 milligrams per liter). Gross alpha and gross beta activity in ground water provide evidence the water had been exposed to radioactive material, such as uranium. Oxygen and hydrogen isotopic ratios in the ground water indicate the water was recharged at altitudes of about 6,700 to 7,600 feet.

\section{Introduction}

The $\mathrm{C}$ aquifer underlies much of northern Arizona, parts of northwestern New Mexico, and southeastern Utah, and is an important source of water for many users (fig. 1). Named for its primary water-bearing rock unit, the Coconino Sandstone, the $\mathrm{C}$ aquifer has an areal extent of more than $27,000 \mathrm{mi}^{2}$. It is the most productive aquifer in the Little Colorado River Basin. Industry (primarily powerplants and wood processing), individual homeowners, businesses, agriculture, and the municipalities of Flagstaff, Holbrook, Show Low, and Winslow, Arizona, depend upon water from the aquifer. The Department of the Interior (DOI) has important interests and trust responsibilities connected to the aquifer. The USGS, in cooperation with the Bureau of Reclamation (BOR) has been tasked with the collection of geologic, hydrogeologic, and water-chemistry data to determine viability of increased use of water from the aquifer. Base flow of numerous streams, such as Chevelon and Clear Creeks and the Little Colorado River, are sustained by discharge from the aquifer. Parts of these streams support threatened and (or) endangered fish species. The aquifer also represents an important source of water for the Navajo Nation and Hopi Tribe. Water from the aquifer is being considered as an alternate supply to relieve pumping from the $\mathrm{N}$ aquifer-the current source of water for a coal mine and coal slurry pipeline used to transport coal mined from Black Mesa near Keyenta, Arizona, to the Mohave Power Generation Station at Laughlin, Nevada. The Navajo Nation, the Hopi Tribe, and the city of Flagstaff are considering expanding withdrawals from the $\mathrm{C}$ aquifer to meet increasing water needs.

\section{Purpose and Scope}

This report presents data and analyses from a study in support of a Federal effort to evaluate the $\mathrm{C}$ aquifer. The Federal effort is a cooperative effort among the U.S. the Bureau of Reclamation (BOR), the U.S. Geological Survey (USGS), the U.S. Fish and Wildlife Service, the Office of Surface Mining, the Navajo Nation, and the Hopi Tribe. 


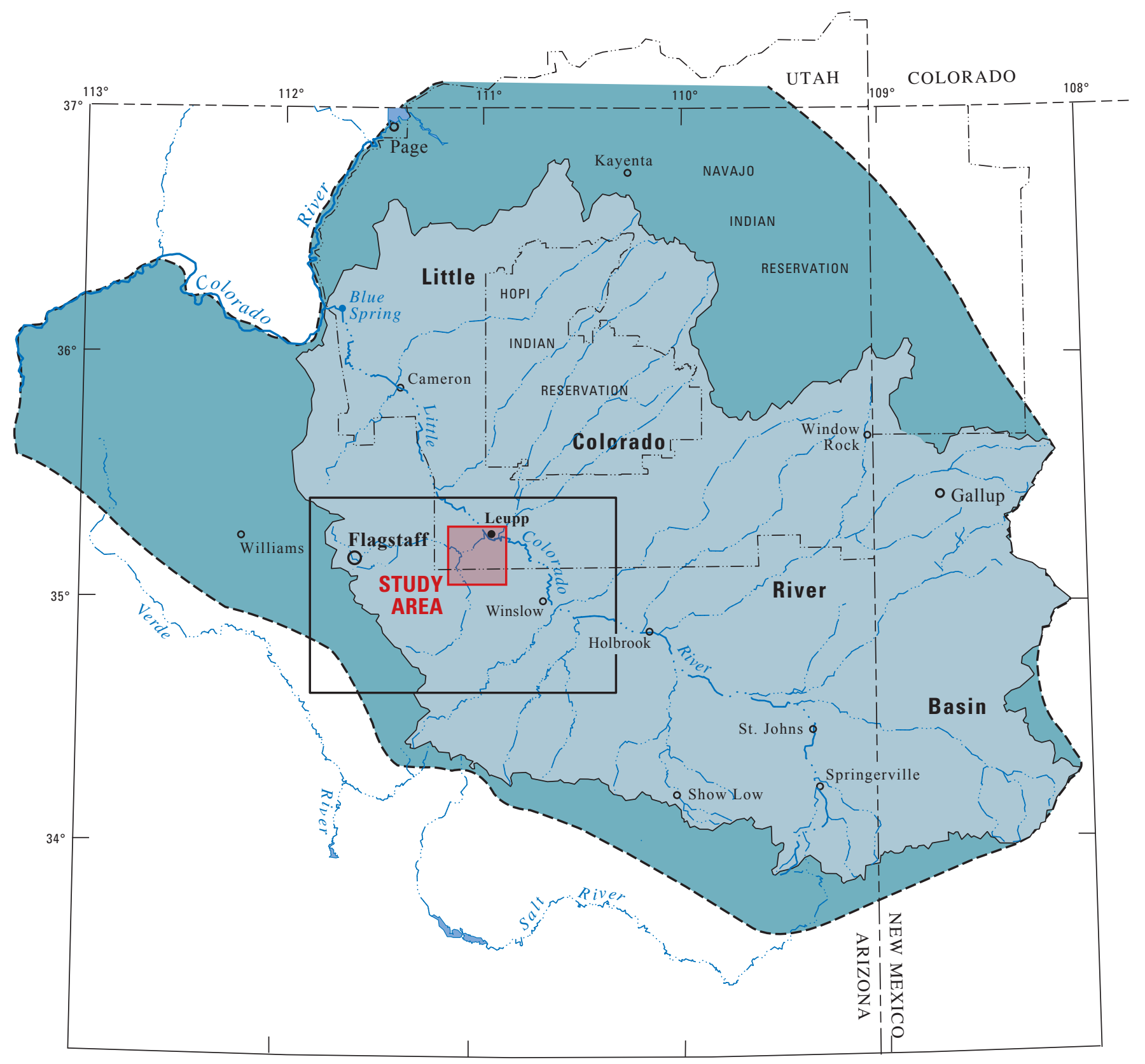

Base from U.S. Geological Survey digital data, 1:100,000, 1980.

Lambert Conformal Conic projection.

Standard parallels $29^{\circ} 30^{\prime}$ and $45^{\circ} 30^{\prime}$,

central meridian $111^{\circ} 30^{\prime}$.

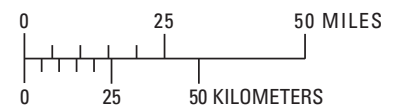

EXPLANATION

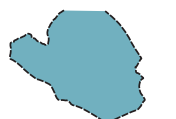

APPROXIMATE EXTENT OF THE C AQUIFER-From Hart and others (2002)

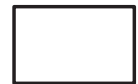

AREA OF FIGURE 2

NAVAJO INDIAN RESERVATION BOUNDARY

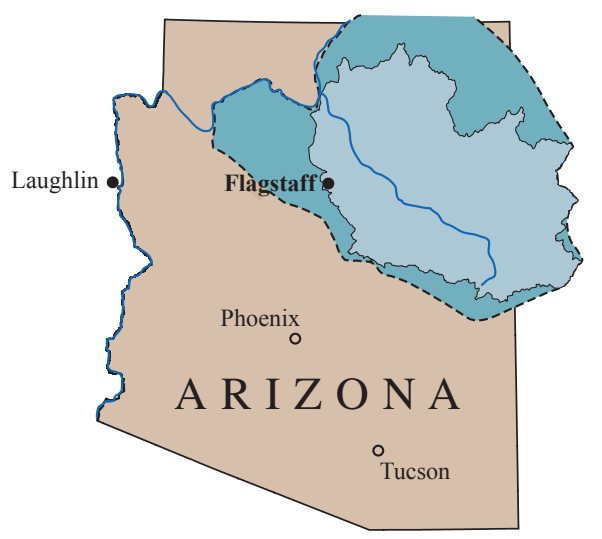

Figure 1. Approximate extent of the $C$ aquifer and location of the study area, northeastern Arizona. 
Data collected for this investigation and presented in this report pertain to well construction, geology, aquifer tests, and water chemistry at three sites within the study area. The study area is roughly a $40 \mathrm{mi}^{2}$ area south of Leupp, Arizona, on the Coconino Plateau (fig. 1). This report contains graphical and tabular data for water-level drawdown and recovery during the aquifer tests. Well-drilling and well-construction information, combined with pumping rates and drawdown, provide the basic information needed for aquifer-test analyses.

\section{Previous Investigations}

Portions of the $\mathrm{C}$ aquifer have been investigated to evaluate water availability for local needs. Studies by Cooley and others (1969), Mann (1976), Mann and Nemecek (1983), and McGavock and others (1986) have provided a basic hydrologic characterization of the $\mathrm{C}$ aquifer for general water use in the Little Colorado River Basin. Two recent studies have attempted to characterize the aquifer on a regional scale to determine the potential of the hydrologic system to meet regional water demands. An investigation of the aquifer in the area of Flagstaff, Arizona, by Bills and others (2000) included extensive structural mapping, geophysical surveying, determination of hydraulic properties, and chemical and isotopic analyses of ground water. A ground-water budget and a generalized geohydrologic characterization of the entire aquifer were developed by Hart and others (2002). Southwest Ground-water Consultants, Inc., constructed a local groundwater flow model of the aquifer in Leupp, Arizona, area ("Groundwater modeling support for the I-40 and Canyon Diablo wellfields", unpublished report to the Bureau of Reclamation, 2004). The model corresponds to a rectangular 2,400- $\mathrm{mi}^{2}$ part of the aquifer that encompasses East Clear and Chevelon Creeks south and west of Leupp and was used to estimate changes in ground-water levels near proposed well fields and at other existing and proposed demand centers, and changes in base flow of East Clear and Chevelon Creeks. Additional models of the aquifer have been constructed to address Federal, tribal, and industrial interests. The aquifer is an important component of the available water resources in the Little Colorado River Basin. As such, these waters are part of long-standing negotiations to settle water-rights claims in the Little Colorado River Basin. With this backdrop of litigation, the data derived and ground-water flow models developed from these investigations typically are held in confidence and therefore not available in the public domain.

\section{Acknowledgments}

Bradley Prudhom, Mike Miller, and Paris Atherton of the BOR were on-site geologists and directed the drilling activities and helped to coordinate the aquifer tests. Steve Crawford and Art Clark (USGS) supervised the USGS well-drilling crews.
Rodgers and Company, Incorporated, of Albuquerque, New Mexico, drilled selected production and observations wells and conducted the aquifer tests.

\section{Drilling, Well Construction, and Static Water-Level Information}

Test wells were drilled at three sites on the Navajo Indian Reservation to provide information for characterizing hydrogeologic properties of the $\mathrm{C}$ aquifer (fig. 2). The wells were drilled by the USGS Western Region Research and Central Region Research Drilling Units, and Rodgers and Company, Inc., between January and April 2005, and were constructed for use as withdrawal wells or observation wells for aquifer tests. The three sites are near a proposed site of a $\mathrm{C}$ aquifer well field and are $10 \mathrm{mi}$ or less apart from each other. Detailed notes related to drilling, construction, development, and completion were compiled by the BOR (Bradley Prudhom, geologist, Bureau of Reclamation, written commun., 2005).

\section{Site 1}

Three wells (PW-1, PW-1A, and OW-1) were drilled during January-February 2005 at site 1 (fig. 2 and table 1). The wells were drilled by the USGS Western Region Research Drilling Unit using a top-head (TH) drive air rotary rig with hammer bit and water and foam. Test well PW-1 was drilled to a depth of 1,035 ft, but was abandoned because caving resulted in loss of a hammer assembly at about $600 \mathrm{ft}$. The drill stem was recovered and the hole was filled with bentonite and cement. Test well PW-1A was drilled at the location of PW-1 to a depth of 1,134 ft and completed with 10-inch insidediameter (ID) steel casing and 10-inch ID continuous-slotted (0.040-inch openings, also referred to as "40 slot") steel screen. The well is screened from 837 to $1,077 \mathrm{ft}$ below land surface and was constructed for use as the withdrawal well in the constant-rate aquifer test. Static depth to water in the well is about $614 \mathrm{ft}$. Test well OW-1 was drilled to 1,179 ft and was constructed as an observation well with 6-inch ID steel casing and 6-inch ID continuous-slotted (40 slot) steel screen. It is screened from 686 to $1,086 \mathrm{ft}$ and has a static depth to water of about $615 \mathrm{ft}$. Windmill well 5T-533, which was completed to a depth of $802 \mathrm{ft}$ in 1977, also was used as an observation well during the aquifer test. It also has a static water level of about $615 \mathrm{ft}$. Few construction details are available; however, records indicate that the well was completed to a depth of $802 \mathrm{ft}$ with 6-5/8-inch steel casing that is torch slotted from 597 to $792 \mathrm{ft}$. 

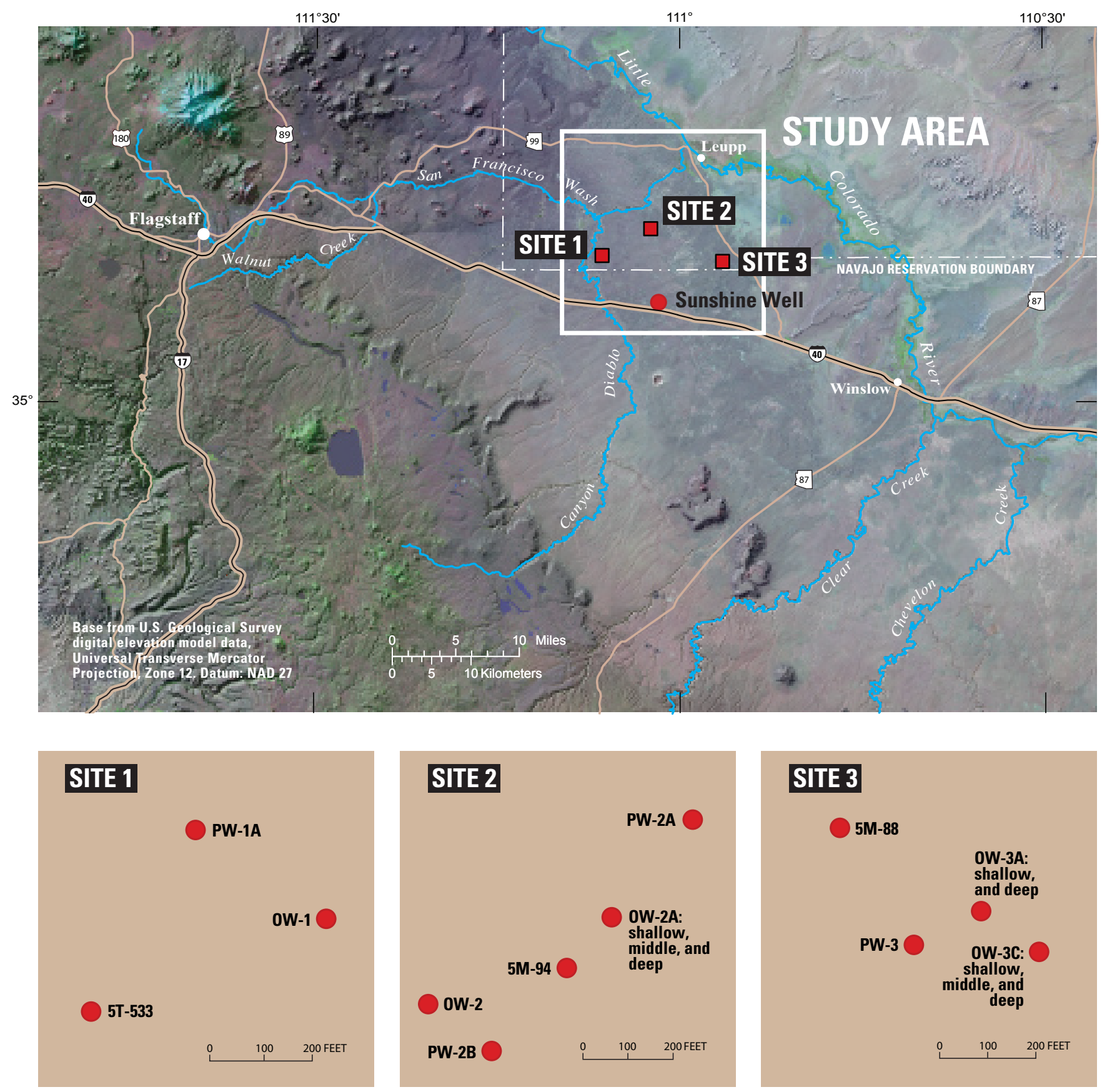

Figure 2. Location of drill sites, test wells, and windmill wells near Leupp, Arizona. 


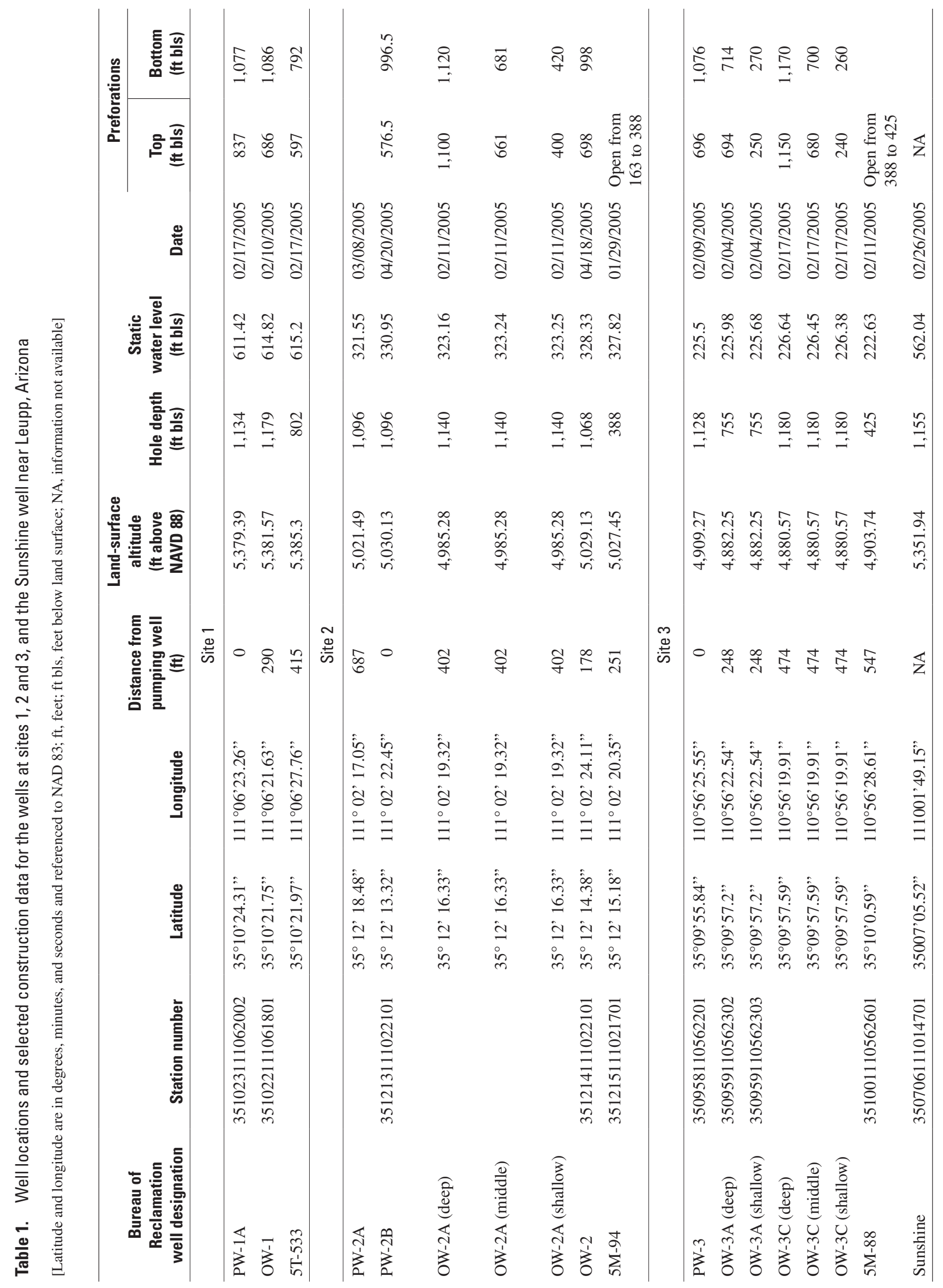




\section{Site 2}

Four wells were drilled between February and April 2005 (fig. 2 and table 1). Test well PW-2A, which was drilled to a depth of 1,096 ft and reamed to $684 \mathrm{ft}$, was abandoned owing to the loss of the reaming drill bit. The well has a surface casing to $55 \mathrm{ft}$, beyond which the well is open to about $500 \mathrm{ft}$. It was used as an observation well during the aquifer test at site 2. Test well PW-2B was drilled to a depth of 1,096 ft and was constructed after the abandonment of PW-2A as the withdrawal well for the constant-rate aquifer test. The well has 10-inch ID continuous-slotted (40 slot) steel screen from 576.5 to $996.5 \mathrm{ft}$ below land surface. Static depth to water at this well is about $328 \mathrm{ft}$. Observation wells at this site, OW-2A and OW-2, were drilled to depths of 1,140 ft and 1,068 ft, respectively. Well OW-2A was completed with a vertical nest of three piezometers. Each piezometer was completed with $20 \mathrm{ft}$ of 2 -inch diameter schedule 80 polyvinyl chloride (PVC) screen (400-420 ft, 661-681 ft, and 1,100-1,120 ft). No vertical water-level gradients were measured at this site, as the static water level in each of the piezometers is about $323 \mathrm{ft}$ below land surface. Well OW-2 was completed with 6-inch ID steel casing to a depth of $698 \mathrm{ft}$ and has 6-inch ID continuous-slotted (40 slot) steel screen from 698 to $998 \mathrm{ft}$. Static water level in the well is about $328.5 \mathrm{ft}$ below land surface. An existing windmill well (5M-94) also was used as an observation well during the aquifer test. This well was completed in 1924 to a depth of $388 \mathrm{ft}$ and has 6-inch steel casing to $163 \mathrm{ft}$. Perforation data are not available for this well; therefore, for the purpose of aquifer-test analysis, it was assumed that the hole is open from 163 to $388 \mathrm{ft}$. Static water level in well 5M-94 is about $324.5 \mathrm{ft}$ below land surface. With the exception of OW-2, wells at site 2 were drilled by the USGS drilling crews using a TH drive rig predominantly with water and foam. Well OW-2 was drilled by Rodgers and Company Inc. with water and bentonite mud.

\section{Site 3}

Three test wells were drilled during January-February 2005 (fig. 2 and table 1). Test well PW-3 was constructed for use as a withdrawal well during the aquifer test. It was drilled to a depth of $1,128 \mathrm{ft}$ and constructed with 10-inch ID continuous-slot (40 slot) steel screen from 696 to 1,076 ft. The static water level in PW-3 is $225.5 \mathrm{ft}$ below land surface. The main observation wells, OW-3A and OW-3C, were drilled to depths of 755 and 1,180 ft, respectively, and were completed with vertical nests of piezometers. Each of the piezometers has $20 \mathrm{ft}$ of 2 -inch diameter schedule $80 \mathrm{PVC}$ screen. In OW$3 \mathrm{~A}$, the shallow piezometer is screened from 250 to $270 \mathrm{ft}$ and the deep piezometer is screened from 694 to $714 \mathrm{ft}$. Well OW-3C has three piezometers - the shallow piezometer is screened from 240 to $260 \mathrm{ft}$, the middle piezometer is screened from 680 to $700 \mathrm{ft}$, and the deep piezometer is screened from 1,150 to $1,170 \mathrm{ft}$. Windmill well $5 \mathrm{M}-88$, which was completed in 1924 to a depth of $425 \mathrm{ft}$. Available construction information for the well is incomplete; however, records indicate that the well was constructed with 6-inch steel casing to a depth of $388 \mathrm{ft}$ and is open below that depth.

\section{Geologic Logs}

Drill-cutting samples were collected at 10-ft intervals in each test well when conditions permitted. A suite of geophysical logs, including gamma, temperature, caliper, self potential, resistivity, electromagnetic, acoustic, and optical, also were collected in selected wells (tables 2-4). Rock units identified in the cuttings are, in descending order, the Moenkopi, Kaibab, and Toroweap Formations, the Coconino Sandstone, the Schnebly Hill Formation, and the Upper Supai Formation (tables 2-4). The Moenkopi Formation is a red to dark-red to reddish brown siltstone, silty sandstone, fine- to very fine grained sandstone, mudstone, and gypsum of Triassic age (McKee, 1954). The formation occurs as a continuous erosional remnant at land surface in the eastern half of the study area and generally does not exceed $50 \mathrm{ft}$ in thickness. The Kaibab Formation, which is Late Permian in age, is primarily a limestone, sand to silty limestone, and dolomitic limestone that is as much as $650 \mathrm{ft}$ thick (Sorauf and Billingsley, 1991). The Kaibab Formation is exposed at land surface in the western part of the study area and is generally less than $200 \mathrm{ft}$ thick. The Toroweap Formation, which underlies the Kaibab Formation, is Late Permian in age (Sorauf and Billingsley, 1991) and comprises carbonate sandstone, red beds, silty sandstone, siltstone, limestone, and thin layers of gypsum. The formation thins to extinction in the eastern part of the study area. The Coconino Sandstone is Permian in age and is a white to tan to light brown, crossbedded, eolian, fine-grained quartz sandstone (Blakey, 1990). The Coconino Sandstone thins eastward in the study area from $1,100 \mathrm{ft}$ to $300 \mathrm{ft}$, and can be extensively fractured where faulted. These fractured zones are likely areas of high permeability and yield the most water to the wells. Where saturated, the Coconino Sandstone is the primary water-bearing unit of the $\mathrm{C}$ aquifer. The Permian Schnebly Hill Formation both interfingers with and underlies the Coconino Sandstone. It comprises a sequence of reddish-brown to reddish-orange very fine to silty sandstone, mudstone, limestone, and dolomite (Blakey, 1990). Thickness of the formation ranges from a few feet north of the study area to as much as $800 \mathrm{ft}$ south of the study area. Within the study area, the formation is predominantly interfingered with the Coconino Sandstone (Hart and others, 2002; Bills and Flynn, 2002; and Bills and others, in press), and is in hydraulic connection with the Coconino Sandstone where it is saturated. McKee (1982) divided the Supai Group into three formations - the upper, middle, and lower-along the Mogollon Rim and at the southern end of the Colorado Plateau. The Upper Supai Formation is a complex series of 
horizontally bedded reddish to brown sedimentary units that are mostly fine-grained sandstone, siltstone, and mudstone. The Middle Supai Formation is a grayish-orange calcareous very fine grained sandstone to siltstone with interbeds of evaporites. The Lower Supai Formation is a red to purple sandstone and siltstone, and gray limestone and dolomite. The Supai Group generally is 1,600 to $2,400 \mathrm{ft}$ thick in the study area. The Upper Supai Formation is the most permeable unit in the group. Drilling during this study did not fully penetrate the Upper Supai Formation.

\section{Site 1}

Geologic units identified in cuttings collected at site 1 include the Kaibab and Toroweap Formations, the Coconino Sandstone, and the Schnebly Hill and Upper Supai Formations. The Kaibab Formation is exposed at land surface at site 1. Thickness of the Kaibab Formation in the test wells is about 192 to $202 \mathrm{ft}$ on the basis of geologic logs from PW-1A and OW-1 (table 2). The Toroweap Formation underlies the Kaibab Formation and ranges from 20 to $40 \mathrm{ft}$ in thickness. Its silt and carbonate content and yellow-orange color are used to distinguish the Toroweap from the underlying Coconino Sandstone; however, the formations are difficult to distinguish in many places. The Coconino Sandstone underlies the Toroweap Formation and, combined with the Schnebly Hill
Formation, is the primary water-bearing unit of the $\mathrm{C}$ aquifer. The Coconino Sandstone extends from 222 to $774 \mathrm{ft}$ below land surface in PW-1A and from 232 to $684 \mathrm{ft}$ in OW-1 (table 2). Beyond these depths, the Coconino Sandstone interfingers with the Schnebly Hill Formation. The layer of interfingered Coconino Sandstone and Schnebly Hill Formation extends to 1,120 ft below land surface in PW-1A and to $1,130 \mathrm{ft}$ below land surface in $\mathrm{OW}-1$, and is underlain by the Upper Supai Formation. Maximum drilling depth at site 1 was $1,179 \mathrm{ft}$, and drilling did not fully penetrate the Upper Supai Formation.

\section{Site 2}

Geologic units identified in cuttings collected at site 2 include the Moenkopi, Kaibab, and Toroweap Formations, the Coconino Sandstone, and the Schnebly Hill and Upper Supai Formations. A shallow north-northwest trending graben was identified near site 2 on the basis of field observations made during the study. The Moenkopi Formation is exposed at land surface and ranges from 15 to $52 \mathrm{ft}$ in thickness in the test wells (table 3). The Kaibab Formation underlies the Moenkopi Formation and ranges from 178 to $180 \mathrm{ft}$ in thickness. A 20-ft-thick section (230 to $250 \mathrm{ft}$ below land surface) of Toroweap Formation was identified in PW-2 beneath the Kaibab Formation.

Table 2. Summary of geologic logs and available geophysical logs from test wells at site 1

[Formation breaks are based on descriptions by U.S. Geological Survey personnel. Formation breaks also were selected by Bureau of Reclamation personnel (Bradley Prudhom, geologist, Bureau of Reclamation, personal commun., 2005) and commonly differed slightly from those selected by U.S. Geological Survey personnel]

\begin{tabular}{|c|c|c|c|}
\hline \multicolumn{2}{|r|}{ Test well PW-1A } & \multicolumn{2}{|r|}{ Test well 0W-1 } \\
\hline $\begin{array}{l}\text { Depth below } \\
\text { land surface } \\
\quad \text { (feet) }\end{array}$ & Formation & $\begin{array}{l}\text { Depth below } \\
\text { land surface } \\
\quad \text { (feet) }\end{array}$ & Formation \\
\hline 0-202 & Kaibab Formation & 0-192 & Kaibab Formation \\
\hline $222-774$ & Coconino Sandstone & $232-684$ & Coconino Sandstone \\
\hline $774-1,120$ & $\begin{array}{l}\text { Layer of interfingered } \\
\text { Coconino Sandstone and } \\
\text { Schnebly Hill Formation }\end{array}$ & $684-1,130$ & $\begin{array}{l}\text { Layer of interfingered } \\
\text { Coconino Sandstone and } \\
\text { Schnebly Hill Formation }\end{array}$ \\
\hline \multicolumn{2}{|c|}{$\begin{array}{l}\text { Self potential (SP), single point resistance, } 16 \text {-inch and } \\
\text { 64-inch normal resistivity, natural gamma, fluid resistivity and } \\
\text { temperature, caliper, acoustic televiewer, and optical televiewer }\end{array}$} & \multicolumn{2}{|c|}{$\begin{array}{l}\text { Self potential (SP), single point resistance, } 16 \text {-inch and } \\
\text { 64-inch normal resistivity, natural gamma, fluid resistivity and } \\
\text { temperature, electromagnetic induction, caliper, and optical } \\
\text { televiewer }\end{array}$} \\
\hline
\end{tabular}


Table 3. Summary of geologic logs and available geophysical logs from test wells at site 2

[Formation breaks for test wells PW-2A and OW-2 are based on descriptions by U.S. Geological Survey personnel. Formation breaks for test wells PW-2B and OW-2A are based on descriptions by Bureau of Reclamation personnel. Formation breaks for test wells PW-2A and OW-2 also were selected by Bureau of Reclamation personnel (Bradley Prudhom, geologist, Bureau of Reclamation, personal commun., 2005) and commonly differed slightly from those selected by U.S. Geological Survey personnel]

\section{Test well PW-2A}

\begin{tabular}{cl}
\hline $\begin{array}{c}\text { Depth below } \\
\text { land surface } \\
\text { (feet) }\end{array}$ & \multicolumn{1}{c}{ Formation } \\
\hline $0-52$ & Moenkopi Formation \\
$52-230$ & Kaibab Formation \\
$230-250$ & Toroweap Formation \\
$250-792$ & Coconino Sandstone \\
& Layer of interfingered Coconino Sandstone \\
$792-1,096$ & and Schnebly Hill Formation \\
& Geophysical logs available
\end{tabular}

Self potential (SP), single point resistance, 16-inch and 64-inch normal resistivity, natural gamma, fluid resistivity and temperature, induction electromagnetic, and caliper
Test well PW-2B

\begin{aligned} & \hline $\begin{array}{c}\text { Depth below } \\ \text { land surface } \\ \text { (feet) }\end{array} \multicolumn{1}{c}{$ Formation } \\ & \hline $0-23$ Moenkopi Formation \\ & $23-205$ Kaibab Formation \\ & $205-755$ Coconino Sandstone \\ & $755-1,057 \begin{array}{r}\text { Layer of interfingered Coconino Sandstone } \\ \text { and Schnebly Hill Formation }\end{array} \\ &$ Upper Supai Formation \\ & \hline\end{aligned}

Geophysical logs available

Self potential (SP), single point resistance, 16-inch and 64-inch normal resistivity, natural gamma, fluid resistivity and temperature, induction electromagnetic, and caliper

\begin{tabular}{|c|c|c|c|}
\hline \multicolumn{2}{|r|}{ Test well OW-2A } & \multicolumn{2}{|r|}{ Test well 0W-2 } \\
\hline $\begin{array}{c}\text { Depth below } \\
\text { land surface } \\
\text { (feet) }\end{array}$ & Formation & $\begin{array}{c}\text { Depth below } \\
\text { land surface } \\
\text { (feet) }\end{array}$ & Formation \\
\hline $0-30$ & Moenkopi Formation & $0-15$ & Moenkopi Formation \\
\hline $210-740$ & Coconino Sandstone & $325-1,050$ & Coconino Sandstone \\
\hline $740-1,057$ & $\begin{array}{l}\text { Layer of interfingered Coconino Sandstone } \\
\text { and Schnebly Hill Formation }\end{array}$ & $1,050-1,080$ & $\begin{array}{l}\text { Layer of interfingered Coconino Sandstone } \\
\text { and Schnebly Hill Formation }\end{array}$ \\
\hline None & & None & \\
\hline
\end{tabular}


Underlying the Toroweap at PW-2, and the Moenkopi at the other test wells, is a layer of Coconino Sandstone and a layer of interfingered Coconino Sandstone and Schnebly Hill Formation. The layer of Coconino Sandstone generally ranges from 530 to $550 \mathrm{ft}$ in thickness; at OW-2 it is 725 -ft thick. The layer of Coconino Sandstone extends to a maximum depth of 1,050 ft below land surface at site 2. Below the layer of Coconino Sandstone, the layer of interfingered Coconino Sandstone and Schnebly Hill Formation ranges from about 260 to $320 \mathrm{ft}$ in thickness at three of the four test wells and extends to a maximum depth of 1,096 ft below land surface.

The Coconino Sandstone and Schnebly Hill Formation could also interfinger in the fourth test well (OW-2), but the relation could not be determined from the drill cuttings. The Upper Supai Formation was identified beneath the layer of interfingered Coconino Sandstone-Schnebly Hill Formation in OW-2, and OW-2A, where drilling extended 10 to $60 \mathrm{ft}$ in the Upper Supai.

\section{Site 3}

The Moenkopi Formation is exposed at land surface at site 3 and generally ranges from 50 to $80 \mathrm{ft}$ in thickness in the test wells (table 4). The underlying Kaibab Formation ranges from 110 to $193 \mathrm{ft}$ in thickness. The Toroweap Formation was identified only at one of the three test wells, PW-3, where it is 20-ft thick. At PW-3, the Coconino Sandstone extends from $200 \mathrm{ft}$ to $680 \mathrm{ft}$ below land surface, beneath which it interfingers with the Schnebly Hill Formation to a depth of $1,100 \mathrm{ft}$. Flowing sand in OW-3A resulted in loss of drillingfluid circulation and prevented the identification of units below $245 \mathrm{ft}$. A layer of interfingered Coconino Sandstone and Schnebly Hill Formation was not identified in OW-3C; however, it is possible that the layer is present. Drilling extended $10 \mathrm{ft}$ into the Upper Supai Formation in OW-3C and $28 \mathrm{ft}$ into the formation in PW-3.

Table 4. Summary of geologic logs and available geophysical logs from test wells at site 3

[Formation breaks are based on descriptions by U.S. Geological Survey personnel. Formation breaks also were selected by Bureau of Reclamation personnel (Bradley Prudhom, geologist, Bureau of Reclamation, personal commun., 2005) and commonly differed slightly from those selected by U.S. Geological Survey personnel]

\begin{tabular}{|c|c|c|c|c|c|}
\hline \multicolumn{2}{|c|}{ Test well PW-3 } & \multicolumn{2}{|c|}{ Test well 0W-3A } & \multicolumn{2}{|c|}{ Test well OW-3C } \\
\hline $0-70$ & Moenkopi Formation & $0-50$ & Moenkopi Formation & $0-80$ & Moenkopi Formation \\
\hline $70-180$ & Kaibab Formation & $52-245$ & Kaibab Formation & $80-210$ & Kaibab Formation \\
\hline $180-200$ & Toroweap Formation & $245-745$ & Coconino Sandstone & $210-1,170$ & Coconino Formation \\
\hline $200-680$ & Coconino Sandstone & & $\begin{array}{l}\text { Flowing sand, could not } \\
\text { complete hole to Upper } \\
\text { Supai Formation }\end{array}$ & $1,170-1,180$ & Upper Supai Formation \\
\hline $1,100-1,128$ & Upper Supai Formation & & & & \\
\hline \multicolumn{2}{|c|}{ Geophysical logs available } & \multicolumn{2}{|c|}{ Geophysical logs available } & \multicolumn{2}{|c|}{ Geophysical logs available } \\
\hline $\begin{array}{l}\text { Self potential }(\mathrm{S} \\
16 \text {-inch and } 6 \\
\text { natural gamm } \\
\text { temperature, } \\
\text { and caliper }\end{array}$ & $\begin{array}{l}\text { ), single point resistance, } \\
\text {-inch normal resistivity, } \\
\text {, fluid resistivity and } \\
\text { lectromagnetic induction, }\end{array}$ & $\begin{array}{c}\text { Self potential } \\
16 \text {-inch and } \\
\text { natural gamn } \\
\text { temperature, } \\
\text { and caliper }\end{array}$ & $\begin{array}{l}\text {, single point resistance, } \\
\text { 4-inch normal resistivity, } \\
\text {, fluid resistivity and } \\
\text { lectromagnetic induction, }\end{array}$ & $\begin{array}{l}\text { Self potential }( \\
16 \text {-inch and } \\
\text { natural gamn } \\
\text { temperature, } \\
\text { caliper, and a }\end{array}$ & $\begin{array}{l}\text { P), single point resistance, } \\
\text { 4-inch normal resistivity, } \\
\text { a, fluid resistivity and } \\
\text { lectromagnetic induction, } \\
\text { oustic televiewer }\end{array}$ \\
\hline
\end{tabular}




\section{Aquifer-Test Analyses}

Multiple-well aquifer tests were conducted at the three sites to estimate hydraulic properties of the $\mathrm{C}$ aquifer. One withdrawal well and a minimum of two observation wells were used for the tests at each site. Wells were pumped for a minimum of 14 days, and water levels were allowed to recover for a minimum of 14 days. Pumping rates ranged from about 400 to $800 \mathrm{gal} / \mathrm{min}$. Generally, each well was instrumented with a pressure transducer (miniTROLL, In-Situ Inc.) that measured water level and temperature at least once every hour. Measurements were made more frequently near the beginning of the pumping period and at the start of the recovery period. When possible, the water level in each well was manually measured several times during the few weeks before pumping began. Manual check measurements were made during the aquifer tests by using electric tapes. Pumping rates for the aquifer tests were determined by conducting step tests at each site before the constant-rate tests. Pumping rates were measured by using an in-line flowmeter or an acoustic flowmeter. A anometer and pressure transducers at the end of the discharge line were used for back-up measurements. A few manual discharge measurements were made by using a pygmy current meter.

Drawdown in each well was estimated by subtracting the water level measured before pumping began from subsequent water levels. When possible, barometric, earth-tide, and regional effects were removed from measured water levels before drawdowns were estimated. The raw water-level data are archived on a BOR FTP site (Bradley Prudhom, geologist, Bureau of Reclamation, written commun., 2005). The data provided in this report are the reduced drawdown values used in the aquifer-test analyses.

The transmissivity, specific yield, specific storage, and vertical anisotropy of the $\mathrm{C}$ aquifer were estimated at each site by using a numerical model. The model was used in the analyses because, unlike analytical solutions, a model can account for heterogeneity caused by layering and can provide estimates of vertical anisotropy. Initial analytical-solution results from use of the Moench solution for unconfined aquifers (Barlow and Moench, 1999) yielded reasonable property estimates that were used as starting values in the numerical models. The numerical models were solved with MODFLOW (McDonald and Harbaugh, 1988; and Harbaugh and McDonald, 1996) and calibrated with MODOPTIM (Halford, 1992). All hydraulic properties were estimated by minimizing the weighted sum-of-squares differences between simulated and measured drawdowns.

In the process of drilling, the permeability of the aquifer in the immediate vicinity of the borehole is reduced. This is referred to as "skin effect." At the onset of pumping, the water level can fluctuate significantly in response to the changes in local permeability. These large fluctuations create considerable noise in the water-level record and typically are difficult to interpret. In addition, well-bore storage in the withdrawal well affects water levels at the beginning of the aquifer test. Thus, water-level values from the withdrawal wells were weighted less than values from the observation wells. Simulated and measured drawdowns in the withdrawal wells were compared after 1 to 2 hours of pumping to minimize the effects of well construction on calibration results.

Simulated drawdowns from the model simulations at sites 1 and 3 are similar to measured drawdowns at the sites; therefore, estimates of aquifer properties derived from the simulations are assumed to be more representative of the regional-scale aquifer properties than model simulations at site 2. Simulated drawdown from the model simulations at site 2 did not always agree with measured drawdown; therefore, estimates of aquifer properties derived from both the analytical methods and the numerical model are presented in this report.

\section{Site 1}

Withdrawal well PW-1A was pumped between March 3 and March 17, 2005, at a rate of about 386 to $412 \mathrm{gal} / \mathrm{min}$ for a total discharge of about $8.1 \times 10^{6}$ gal during the test. The pumping rate was selected on the basis of results from step-drawdown tests in February 2005. In those tests, pumping rates were increased by steps of $50 \mathrm{gal}$; a rate of $450 \mathrm{gal} / \mathrm{min}$ caused the water level to decline below the top of the well screen. Water was discharged into Canyon Diablo, about 2,300 ft from well PW-1A, and flowed away from the site. Given the distance from the pumping well, the local geology, and the depth to water, there is a small likelihood that the discharged water would have recharged the aquifer during the test. The aquifer test was simulated with four stress periods: three periods in which well PW-1A was pumped at a rate of 386 to $412 \mathrm{gal} / \mathrm{min}$, and one recovery period.

Well OW-1 and windmill well 5T-533 were used as observation wells during the aquifer test. Drawdowns in each of the three wells (PW-1A, OW-1, and 5T-533) for the pumping and recovery period of the test are shown in figure 3 . The specific capacity of PW-1A was about $2(\mathrm{gal} / \mathrm{min}) / \mathrm{ft}$, on the basis of a maximum drawdown of $204.5 \mathrm{ft}$ and a pumping rate of $400 \mathrm{gal} / \mathrm{min}$ (table 5).

The aquifer system was simulated with a radial model that incorporated the withdrawal well and observation wells OW-1 and 5T-533. The geology was generalized into three units on the basis of geologic logs: the Coconino Sandstone, the layer of interfingered Coconino Sandstone and Schnebly Hill Formation, and the Upper Supai Formation. Homogeneous hydraulic conductivity was assumed for each unit. Vertical anisotropy (a ratio of the vertical to horizontal hydraulic conductivity other than 1) also was assumed. 


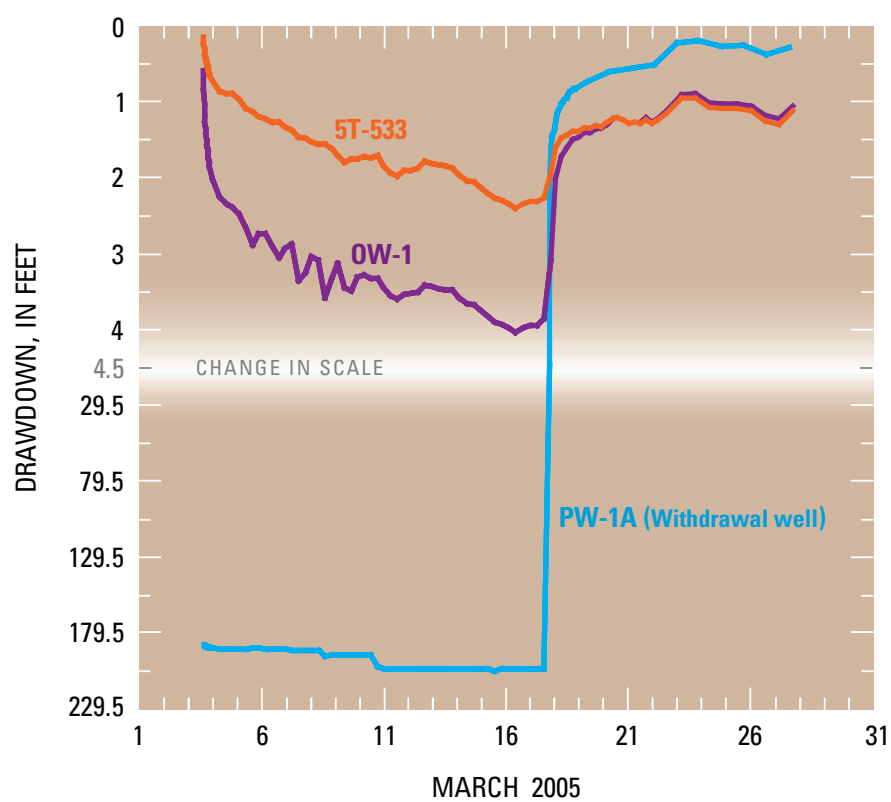

Figure 3. Filtered water-level drawdown and recovery at site 1 during aquifer test near Leupp, Arizona.
The model was discretized into 84 rows and 69 columns and extended laterally 200,000 ft from PW-1A. The vertical extent of the model was from 615 to $1,500 \mathrm{ft}$ below land surface. The upper boundary of the model was the water table. The bottom boundary of the model was $885 \mathrm{ft}$ below the water table and was represented as the bottom of the Upper Supai Formation. Column widths were $0.2 \mathrm{ft}$ near well PW-1A and increased in width by a factor of 1.2 to the edge of the model. Row thicknesses were $1 \mathrm{ft}$ adjacent to changes in lithology and increased by a factor of 1.5 to the midpoint of each unit. All external boundaries were no-flow. Changes in the wetted thickness of the aquifer were not simulated because, except near the withdrawal well, the drawdown near the water table was small relative to the thickness of the aquifer.

Initial simulations with a uniform hydraulic conductivity were not successful in matching simulated drawdowns with measured drawdowns. Consequently, hydraulic properties then were allowed to vary for each of the primary lithologic units (Coconino Sandstone and the layer of interfingered Coconino Sandstone and Schnebly Hill Formation). The hydraulic conductivity value for the Upper Supai Formation and the vertical anisotropy values were held constant and were estimated on the basis of aquifer-test results from site 3 .

Table 5. Estimated hydraulic properties from numerical-model simulations at test-well sites 1, 2, and 3 near Leupp, Arizona

$[(\mathrm{gal} / \mathrm{min}) / \mathrm{ft}$, gallons per minute per foot of drawdown; $\mathrm{ft} / \mathrm{d}$, foot squared per day; ft/d, foot per day; NC, not calculated; ft-1, per foot. Specific-capacity values were determined during constant-rate aquifer test]

\begin{tabular}{|c|c|c|c|}
\hline Hydraulic property & Site 1 & Site 2 & Site 3 \\
\hline Specific capacity, $(\mathrm{gal} / \mathrm{min}) / \mathrm{ft}$ & 2 & 7.5 & 2.4 \\
\hline Hydraulic conductivity of Coconino Sandstone, $\mathrm{ft} / \mathrm{d}$ & 28 & 42 & 11 \\
\hline $\begin{array}{l}\text { Hydraulic conductivity of interfingered of the } \\
\text { Coconino Sandstone/Schnebly Hill Formation, } \mathrm{ft} / \mathrm{d}\end{array}$ & 8 & .04 & .9 \\
\hline Hydraulic conductivity of Upper Supai Formation, $\mathrm{ft} / \mathrm{d}$ & ${ }^{1} .1$ & $\mathrm{NC}$ & .2 \\
\hline Vertical-to-horizontal anisotropy, dimensionless & .5 & ${ }^{1} .2$ & .17 \\
\hline
\end{tabular}

${ }^{1}$ Estimated on the basis of results from site 3 . 
Measured drawdown and recovery in PW-1A, OW-1, and 5T-533 were compared with simulated drawdowns and recovery from the numerical model (fig. 4). Simulated water levels matched measured water levels with a root-mean-square (RMS) error of $0.3 \mathrm{ft}$ for the observation wells.

Estimated hydraulic conductivity was about $28 \mathrm{ft} / \mathrm{d}$ for the Coconino Sandstone and about $8 \mathrm{ft} / \mathrm{d}$ for the layer of interfingered Coconino Sandstone and Schnebly Hill Formation (table 5); hydraulic conductivity of the Upper Supai Formation was set at $0.1 \mathrm{ft} / \mathrm{d}$ in the model on the basis of estimates from aquifer tests at site 3 (there was no piezometer screened in the Upper Supai Formation at site 1). Estimated specific storage was $2 \times 10^{-6} \mathrm{ft}^{-1}$, and estimated specific yield was 0.06 . The hydraulic conductivity of the three units corresponds to a transmissivity of $7,000 \mathrm{ft}^{2} / \mathrm{d}$; most of the transmissivity can be attributed to the Coconino Sandstone. The vertical-to-lateral anisotropy of the aquifer system was set to 0.5 in the model.

\section{Site 2}

Withdrawal well PW-2B was pumped from April 26 through May 10, 2005, at a rate of about $745 \mathrm{gal} / \mathrm{min}$. The rate was selected on the basis of results from step-drawdown tests in April 2005. In those tests, rates were increased by steps of $200 \mathrm{gal} / \mathrm{min}$; a rate of $800 \mathrm{gal} / \mathrm{min}$ resulted in a drawdown of about $139 \mathrm{ft}$. A total discharge of about $13.8 \times 10^{6}$ gal was pumped during the constant-rate aquifer test. The water discharged to a dry channel about $750 \mathrm{ft}$ from well PW-2B and then flowed to a stock tank about 7,000 ft north of the site. Pumping rates were measured by using a combination of an in-line flowmeter, a manometer, a pygmy current meter, and an acoustic flowmeter.

One withdrawal well (PW-2B), a nest of three piezometers (OW-2A), and three observation wells (PW-2A, OW-2, and 5M-94) were used for the aquifer test (table 1 and fig. 2). Most wells were instrumented with a pressure transducer, although manual water-level measurements were made at PW-2A and 5M-94. These data were collected by Rodgers and Company, Inc., and provided to the BOR. The specific capacity of PW-2B was about 7.5 (gal $/ \mathrm{min}) / \mathrm{ft}$ on the basis of a drawdown of $100 \mathrm{ft}$ and a pumping rate of $745 \mathrm{gal} / \mathrm{min}$ (table 5).

Drawdowns at site 2 did not respond as expected, given the responses measured at sites 1 and 3 . For example, drawdowns in OW-2A were virtually the same at each of the three piezometers. On the basis of aquifer-test results from site 3 and the short distance between the withdrawal well and OW-2A, it was expected that drawdown would be greatest in the deep piezometer (an indication of confined aquifer conditions) and smallest in the shallow piezometer (an indication of a water-table response). Maximum drawdown in the piezometers was about $0.6 \mathrm{ft}$ (fig. 5). Although the screened intervals in the piezometers are separated by more than $100 \mathrm{ft}$ of bentonite seal, it is possible that they are not hydraulically isolated. Drawdown in PW-2A was measured manually with an electric tape. The drawdown in this well, which is almost $300 \mathrm{ft}$ farther from the withdrawal well than the piezometers at OW-2A, was slightly greater than the drawdown in the piezometers. The water-level in PW-2A never fully recovered during the measurement period. At well 5M-94, both the manual tape-down measurements and the pressure-transducer data were considered in the analysis owing to a partial failure of the pressure transducer.

The transmissivity, specific yield, specific storage, and vertical anisotropy of the $\mathrm{C}$ aquifer at site 2 were estimated with straight-line analytical methods (Cooper and Jacob, 1946) and a numerical model. The confidence in these estimates is less than that for estimates at sites 1 and 3 because (1) the analytical estimates produced inconsistent results (fig. 6) and (2) the simulated drawdown from the numerical model does not adequately match the measured drawdown. The inconsistent results likely are due to uncertainties in the drawdown data. Estimates of aquifer properties at site 2 derived from analytical and numerical methods are provided to indicate a range of possible values.

The straight-line method of drawdown versus distance from pumping yielded an estimated transmissivity of $7,500 \mathrm{ft}^{2} / \mathrm{d}$ and a storage value of 0.2 . The straight-line method of drawdown versus time yielded an estimated transmissivity of $52,600 \mathrm{ft}^{2} / \mathrm{d}$ (fig. 6). These values are considered rough estimates for many of the same reasons described in the following discussion about the numerical model results.

The aquifer system at site 2 was simulated with a threedimensional model. The geology was generalized into two units on the basis of geologic logs. Hydraulic conductivity was assumed homogeneous and vertically anisotropic within each unit. Model simulations produced hydraulic-conductivity estimates that ranged from 0.04 to $42 \mathrm{ft} / \mathrm{d}$ and a specific yield of 0.08 (table 5). The hydraulic conductivity of the combined units corresponds to a transmissivity of $18,000 \mathrm{ft}^{2} / \mathrm{d}$; most of the transmissivity can be attributed to the Coconino Sandstone. The model-estimated vertical-to-horizontal anisotropy of the aquifer system was about 0.2 (table 5).

Although estimated aquifer properties were obtained from the numerical model simulations, the confidence in these estimates is less than that for estimates at sites 1 and 3. The lower confidence is attributed to the uncertainty of measured data, the poor fit of simulated to measured drawdown values, and the nonuniqueness of the model domain. For the estimate of drawdown in well 5M-94, the water level was assumed to have fully recovered by the end of the test. Water levels in PW-2A are questionable because construction details could not be verified owing to the loss of the drill bit and stem. Water levels in the piezometers behaved similarly, which indicates the possibility that the piezometers were not hydraulically isolated during well construction. Simulated drawdown did not match well with measured drawdown in monitor wells OW-2 or PW-2B (fig. 7A). Although measured drawdown in some wells was approximated by simulations (fig. 7B), the properties of the model domain had to be varied beyond values that can be justified on the basis of field data. For example, in order to obtain the simulated results for this site, a zone of low permeability close to the water table was applied, and the fault zone was represented by a zone of low permeability. 


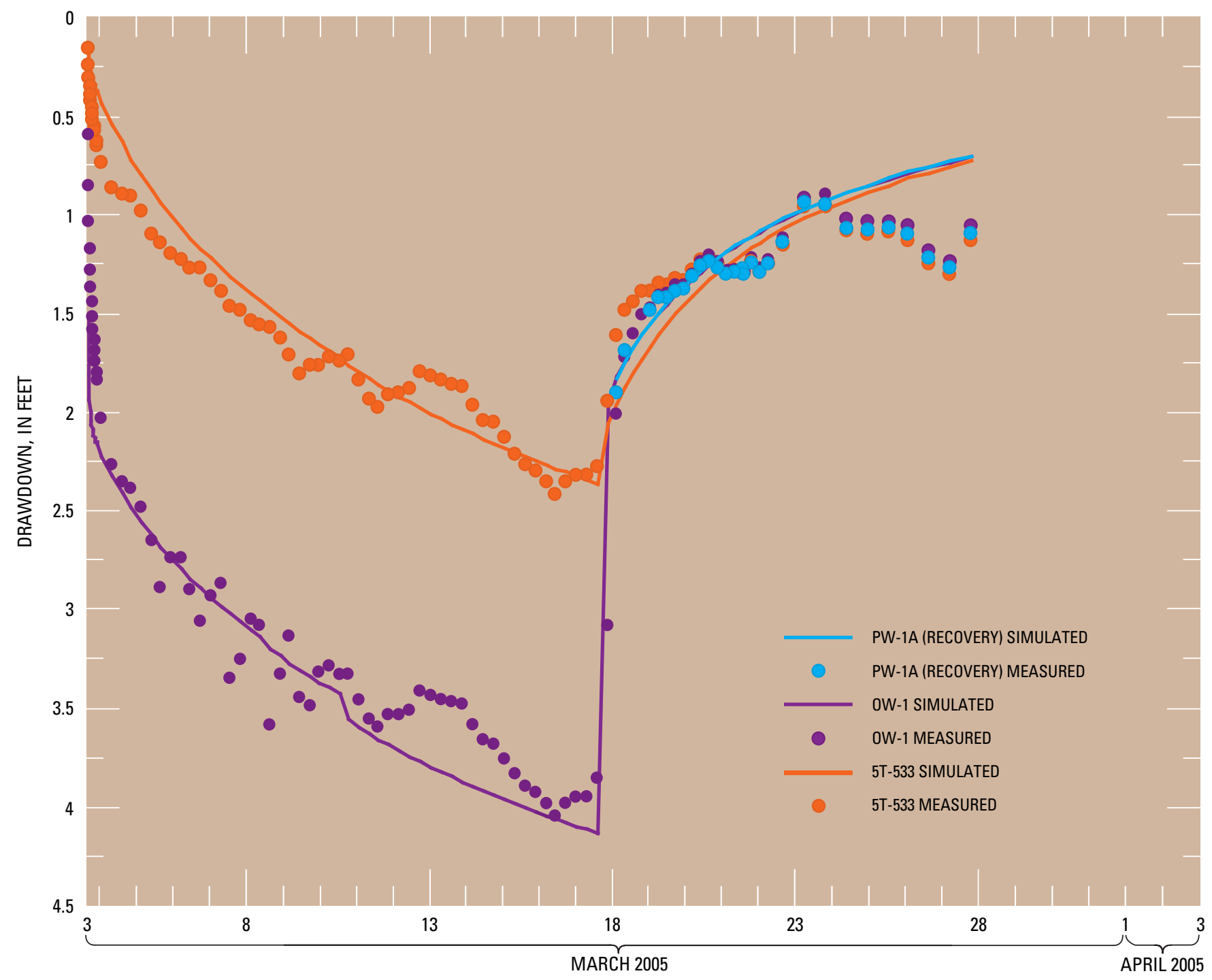

Figure 4. Simulated and measured water-level drawdown in PW-1A, 0W-1, and windmill well 5T-533 near Leupp, Arizona. 


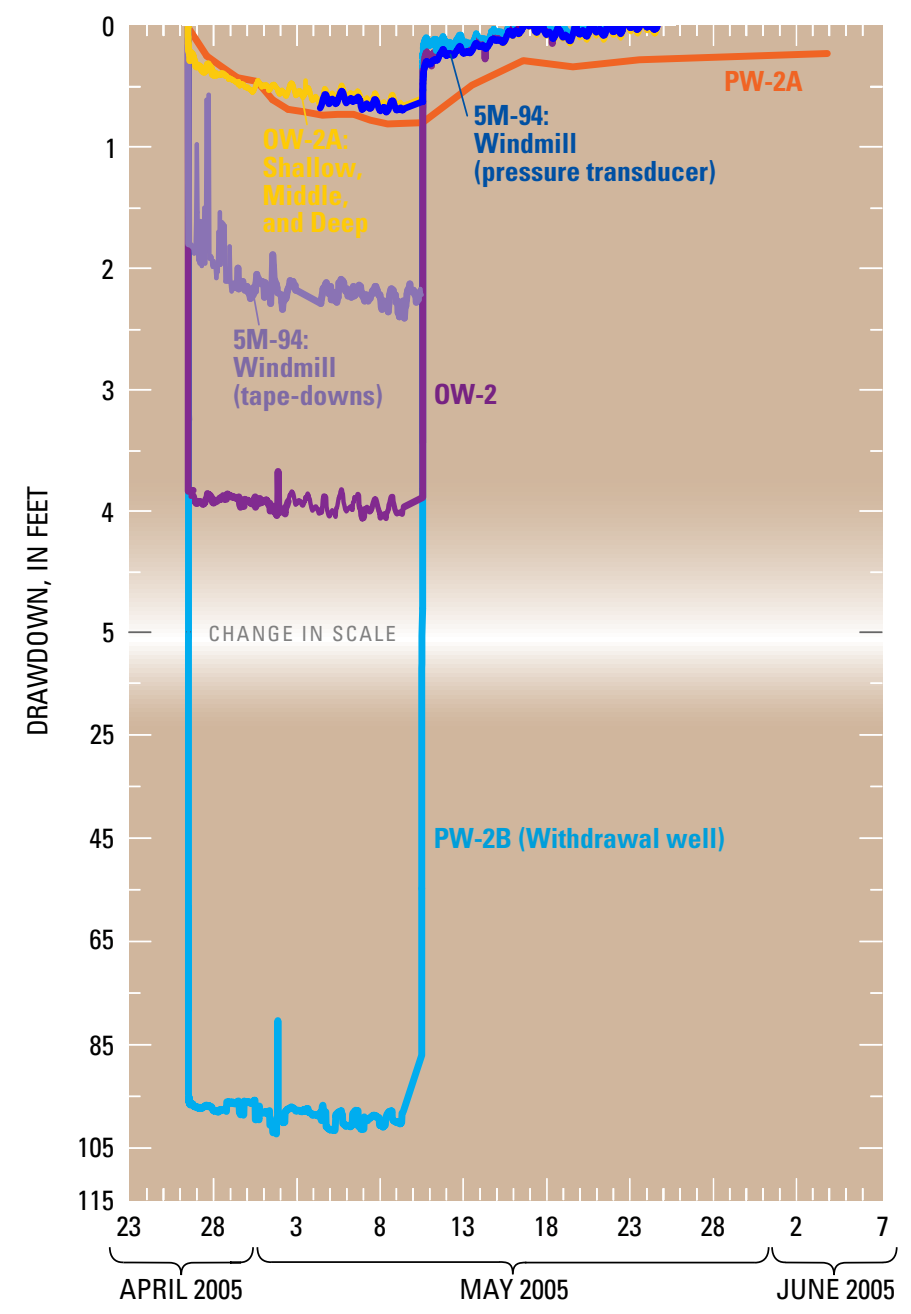

Figure 5. Water-level drawdown during aquifer test at site 2 near Leupp, Arizona.

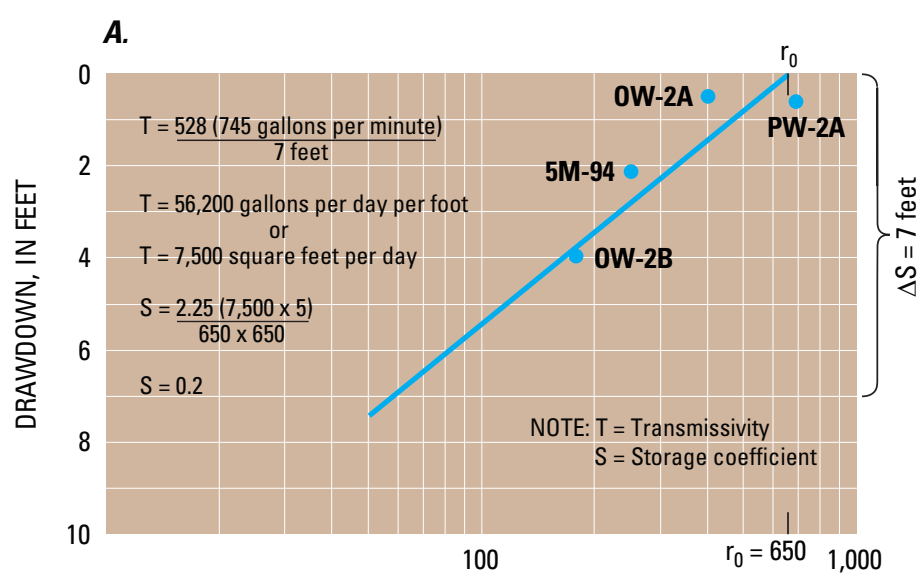

DISTANCE FROM WITHDRAWAL WELL, IN FEET

$T=\underline{528(0)}$, where $T=$ transmissivity in gallons per day per foot $0=$ gallons per minute $\Delta S=$ drawdown over one log cycle

(To convert $\mathrm{T}$ from gallons per day per foot to square feet per day, $\mathrm{T}$ is divided by 7.481.)

$$
\begin{aligned}
S=\frac{2.25 \mathrm{~T} t}{\mathrm{r}_{0}{ }^{2}} \text { where } \mathrm{T} & =\text { transmissivity in square feet per day } \\
\mathrm{t} & =\text { time since pumping started, in days } \\
\mathrm{r}_{0} & =\text { intercept of extended straight line where drawdown } \\
& \text { equals zero, in feet }
\end{aligned}
$$

\section{B.}

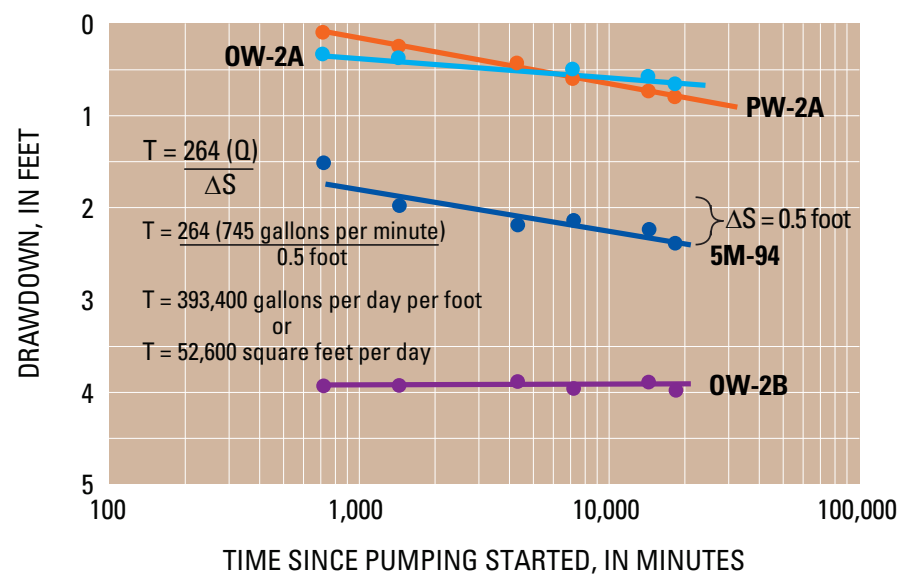

Figure 6. Straight-line methods to estimate transmissivity and storage coefficient at site 2 near Leupp, Arizona. A, Distance drawdown; $B$, Time drawdown. 
A.

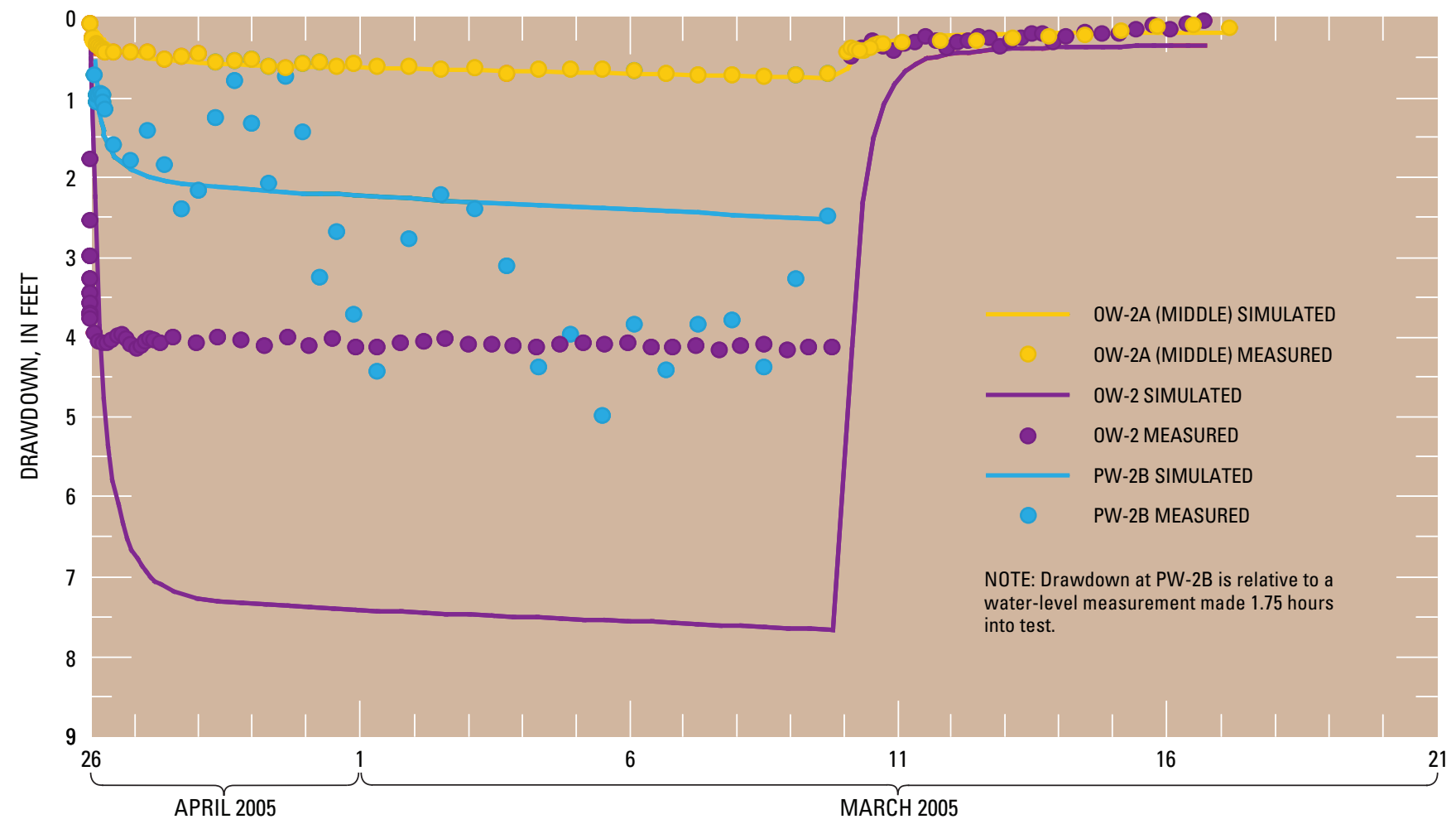

B.

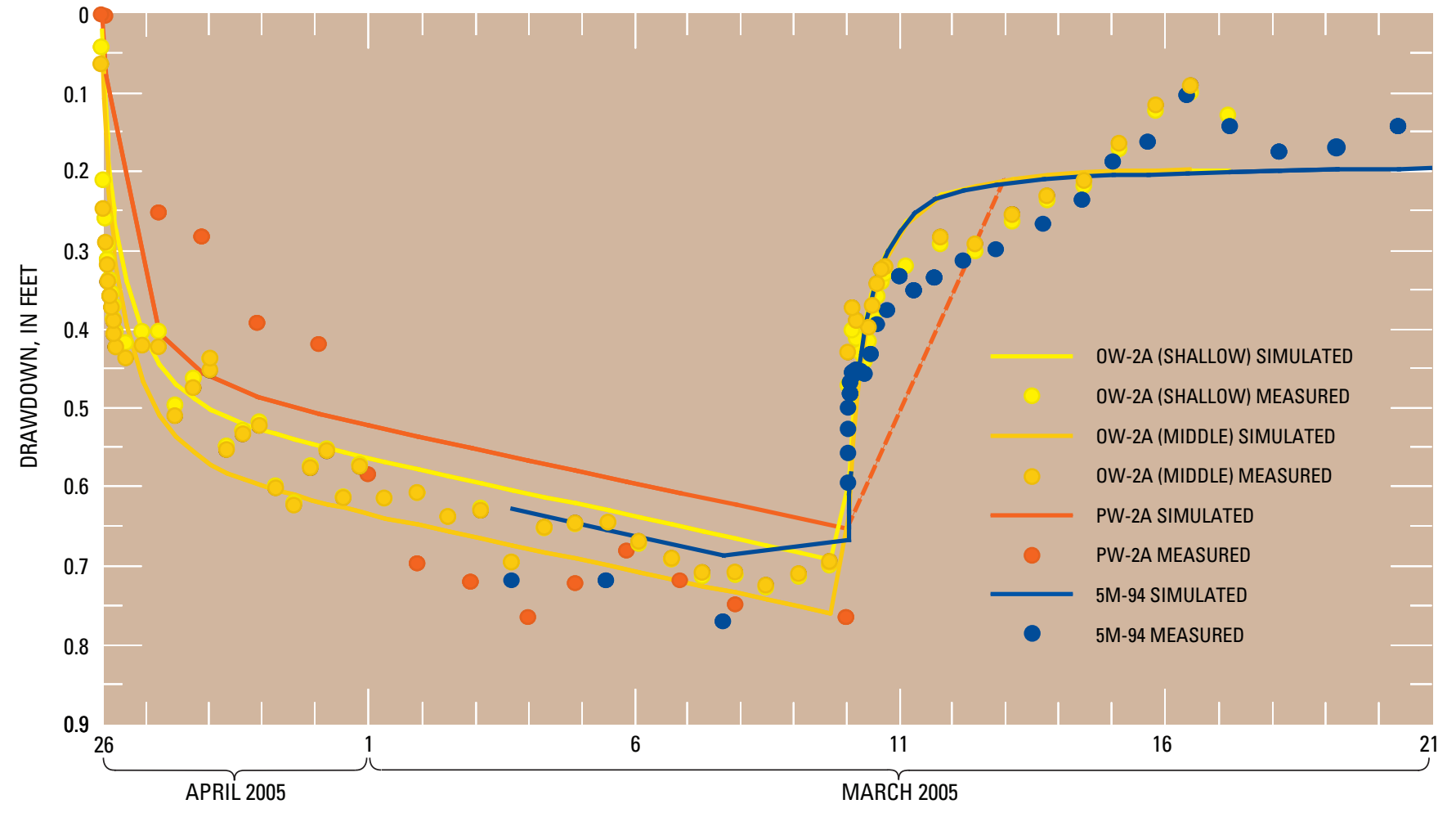

Figure 7. Simulated and measured water-level drawdown at site 2 near Leupp, Arizona. $A, 0 \mathrm{~W}-2 \mathrm{~A}$ (middle), $\mathrm{OW}-2$, and PW-2B; $B, 0 \mathrm{~W}$ $2 \mathrm{~A}$ (shallow), OW-2A (middle), PW-2A, and 5M-94. 


\section{Site 3}

Aquifer-test results from site 3 are deemed more reliable than those from sites 1 and 2 owing to the duration of the aquifer test and the distribution of the water-level measurements. The aquifer test at site 3 included two pumping periods and two recovery periods. The first pumping period extended from February 26 through March 5, 2005, during which the pumping rate was about $795 \mathrm{gal} / \mathrm{min}$. The second period extended from March 11 to March 25, 2005, during which the pumping rate was $775 \mathrm{gal} / \mathrm{min}$. Recovery was measured between the two pumping periods and after the second pumping period until April 8, 2005. The pumping rate was selected on the basis of results from step-drawdown tests in February 2005. In those tests, pumping rates were increased by steps of 100 to $250 \mathrm{gal} / \mathrm{min}$; a rate of $750 \mathrm{gal} / \mathrm{min}$ resulted in a drawdown of about $306 \mathrm{ft}$. Total discharge was about $24.5 \times 10^{6}$ gal during the test. Water discharged into a dry channel about $500 \mathrm{ft}$ from well PW-3 and flowed away from the test site. Pumping rates were measured using an inline flowmeter. A manometer at the end of the discharge line was used for back-up measurements. One withdrawal well, five piezometers, and one observation well were used for the aquifer test (table 1 and fig. 2). Water levels were measured in the wells throughout the pumping and recovery periods (fig. 8). The specific capacity of PW-3 was about 2.4 (gal/ $\mathrm{min}$ )/ft on the basis of a drawdown of $325 \mathrm{ft}$ and a pumping rate of $775 \mathrm{gal} / \mathrm{min}$ (table 5).

The aquifer system at site 3 was simulated with a radial model that incorporated the piezometers in wells OW-3A and $\mathrm{OW}-3 \mathrm{C}$, and windmill well 5M-88. The geology at site 3 was generalized into four units on the basis of geologic logs. Hydraulic conductivity was assumed to be homogeneous and vertically anisotropic within each unit.
The model domain was discretized into 78 rows and 69 columns, and extended laterally 200,000 ft from PW-3. The vertical extent of the model was from 227 to $1,500 \mathrm{ft}$ below land surface. The upper boundary of the model was the water table and was represented by the uppermost row at a depth of $227 \mathrm{ft}$. The bottom of the model was 1,273 ft below the water table and was represented as the bottom of the Upper Supai Formation. Column widths were $0.2 \mathrm{ft}$ near well PW-3 and increased in width by a factor of 1.2 to the edge of the model. Row widths were $1 \mathrm{ft}$ adjacent to changes in lithology and increased by a factor of 1.5 to the midpoint of each unit. All external boundaries were no-flow. Changes in the wetted thickness of the aquifer were not simulated because, except near the withdrawal well, the drawdown near the water table was small relative to the thickness of the aquifer. The aquifer test was simulated with four stress periods that represent two pumping periods and two recovery periods.

Initial simulations with a uniform hydraulic conductivity were not successful in matching simulated drawdowns with measured drawdowns. Consequently, the hydraulic conductivity was allowed to vary by unit. Measured drawdowns in piezometers at OW-3A and OW-3C, and in 5M-88 were compared with simulated drawdowns from the numerical model (fig. 9). Simulated drawdowns matched measured drawdowns with an RMS error of $1.2 \mathrm{ft}$.

Estimated hydraulic conductivity of the four units ranged from 0.2 to $11 \mathrm{ft} / \mathrm{d}$; estimated specific storage was $2 \times 10^{-6} \mathrm{ft}^{-1}$; and estimated specific yield was 0.05 (table 5). The hydraulic conductivity of the four units corresponds to a transmissivity of $5,400 \mathrm{ft}^{2} / \mathrm{d}$; most of the transmissivity can be attributed to the Coconino Sandstone. The model-estimated vertical-tohorizontal anisotropy of the aquifer system was 0.17 (table 5). 
A.

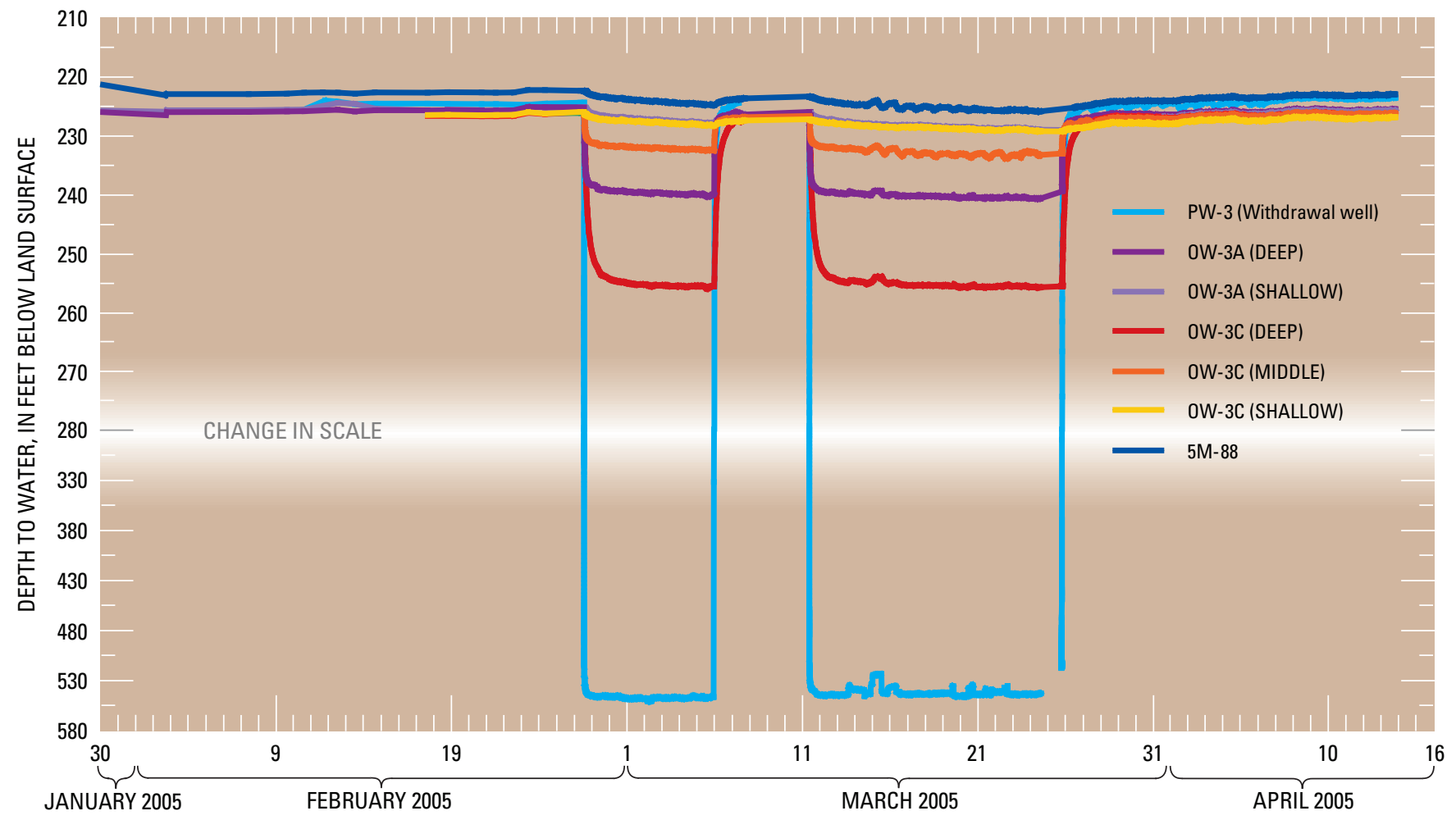

B.

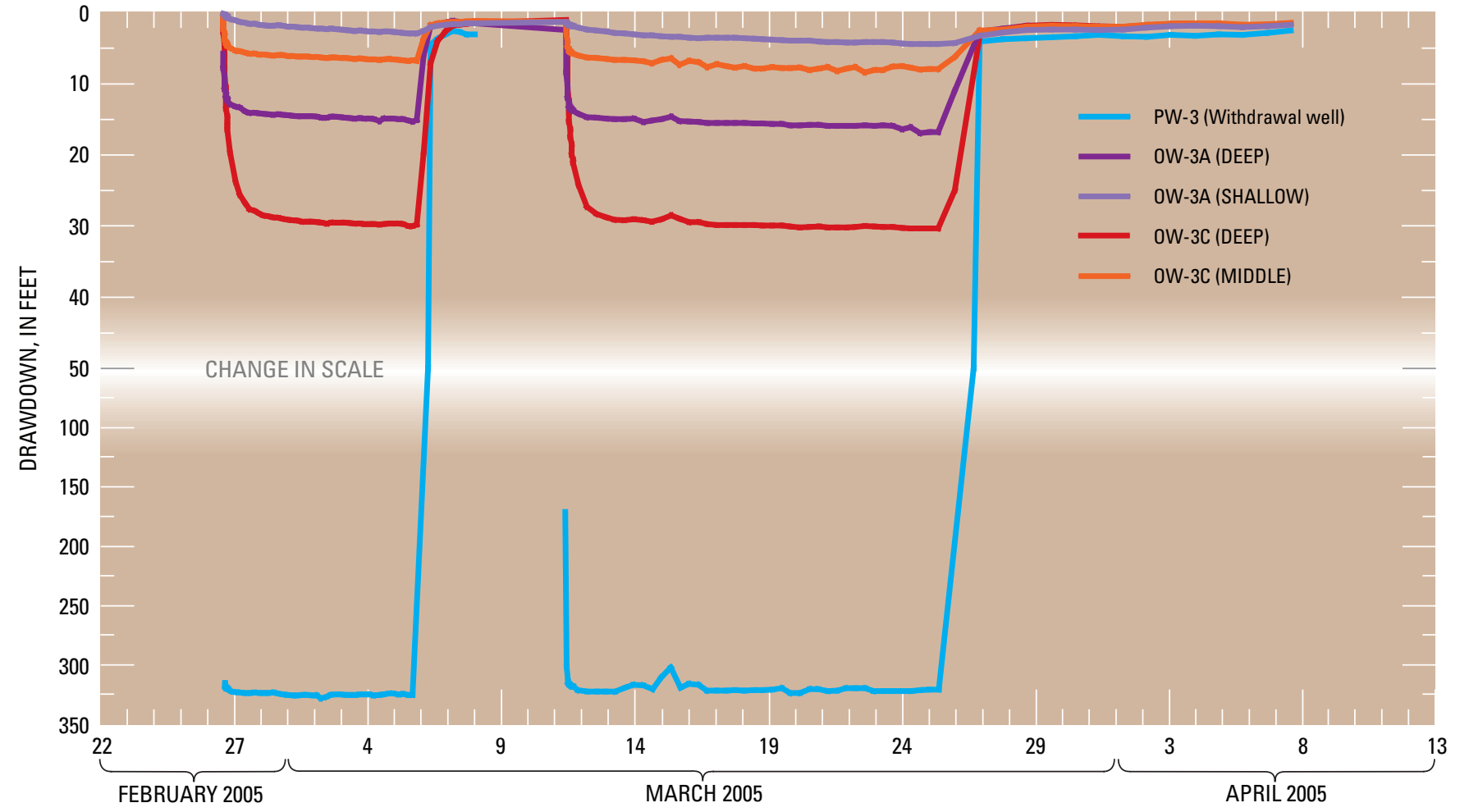

Figure 8. Water-level record at site 3 near Leupp, Arizona. $A$, Depth to water; $B$, Water-level drawdown. 
A.

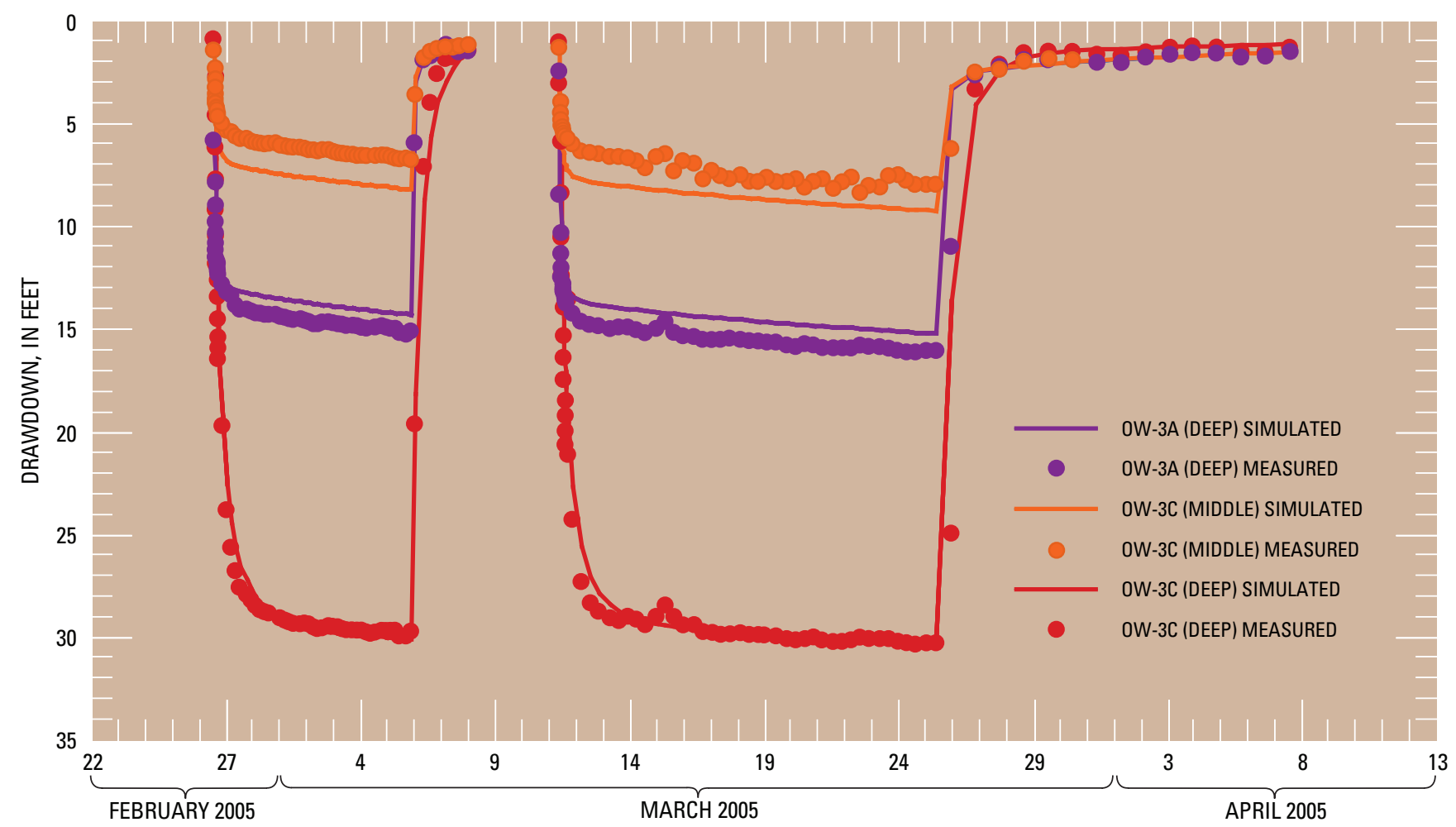

B.

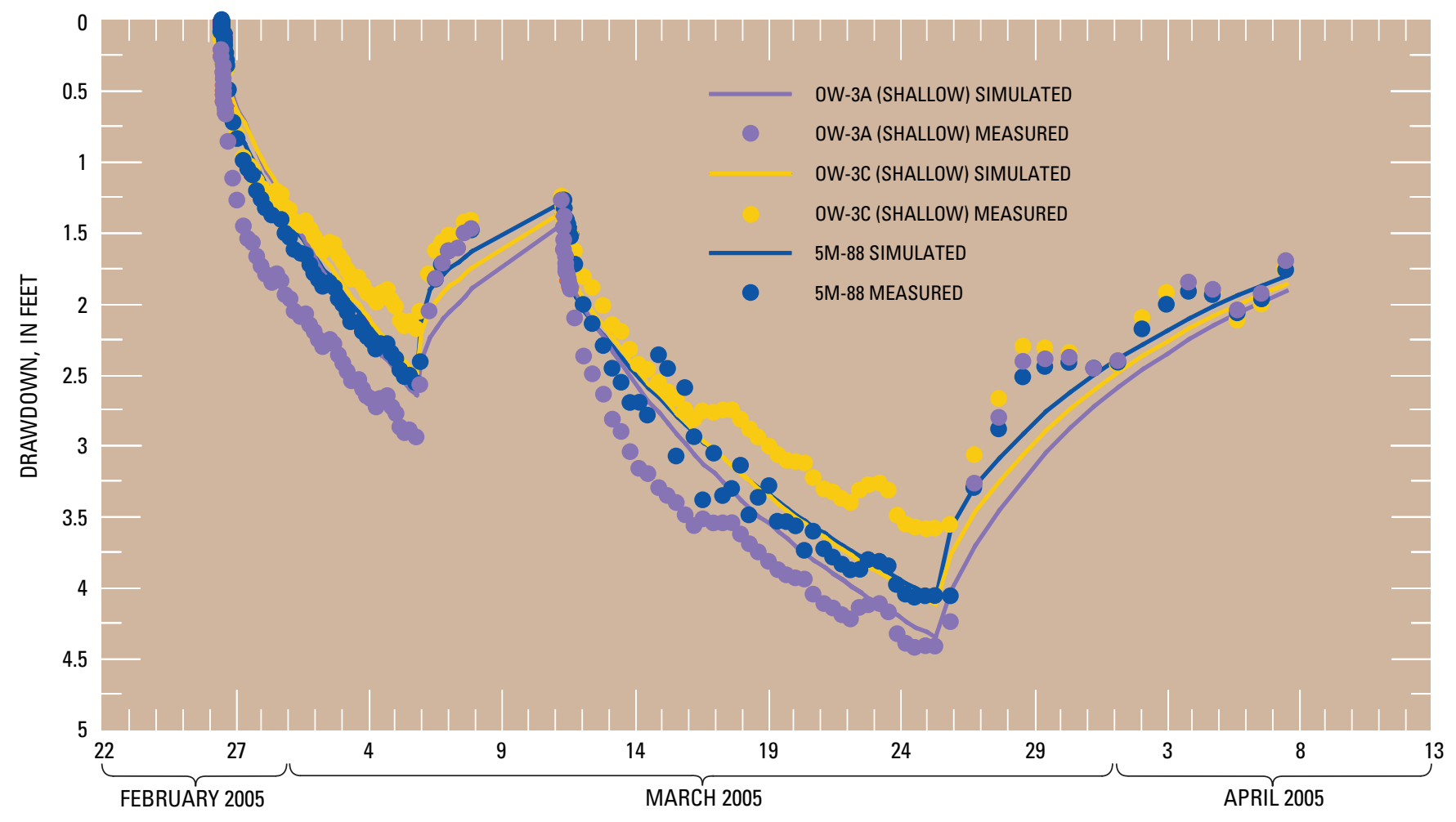

Figure 9. Water-level record at site 3 for period prior to pumping and during pumping and recovery periods of aquifer tests, near Leupp, Arizona. The first pumping period extended from February 26 through March 5, 2005 and the second period was between March 11 and March 25, 2005. Recovery was measured between pumping periods and until April 7, 2005. A. Depth to water for period prior to pumping, and during pumping and recovery periods of constant-rate aquifer tests. B. Drawdown in wells during constant-rate aquifer tests. 


\section{Water Chemistry}

Ground-water sample collection during this investigation followed protocols described in the National Field Manual for the Collection of Water Quality Data (U.S. Geological Survey Techniques of Water Resources Investigations, chapter 9A, variously dated). The samples were analyzed by the USGS National Water Quality Laboratory in Denver, Colorado, for major ions, nutrients, trace elements, stable isotopes, and radioisotopes. Selected water properties and constituents were measured on-site during sample collection. Samples collected for major-ion and trace-element analyses were filtered through a 0.45 -micrometer capsule filter into acid-rinsed bottles and preserved with nitric acid.

Samples were acquired under one of the following conditions: well development, step-test, or constantrate aquifer test. Pumping rate, water level, $\mathrm{pH}$, specific conductance, water temperature, dissolved-oxygen concentration, alkalinity, and chloride concentration were monitored during well development and pumping. Samples were collected only after confirming that successive measurements of these properties and constituents showed negligible change. Water samples were collected from the well head during development and from the discharge line for the step and constant-rate tests. Sample collection during the constant-rate aquifer tests occurred near the end of each test. Eighteen water samples were collected at the three drill sites from February 9, 2005, to May 9, 2005 (table 6). In addition, two samples were collected from a nearby inactive windmill well that is occasionally used for livestock watering (Sunshine well; fig. 2 and table 6). The Sunshine well is south of the three test sites and is owned by the Hopi Tribe. Available construction information for the well is incomplete; however, a sounding of the well indicated a depth of about $736 \mathrm{ft}$ (Bradley Prudhom, geologist, Bureau of Reclamation, written commun., 2005), and records for this well in the USGS Ground-Water Site-Inventory database indicate a depth of $1,155 \mathrm{ft}$.

On-site measurements of water properties and constituents for all sampling conditions were similar among the sites. Specific conductance was lowest at site 2 ( 837 to $850 \mu \mathrm{S} / \mathrm{cm}$; table 6 ) and highest at site 3 $(1,160$ to $1,230 \mu \mathrm{S} / \mathrm{cm})$. Specific conductance and chloride increased slightly near the end of the constant-rate test at site 3. At the three test sites and the Sunshine well, values of $\mathrm{pH}$ ranged from 7.2 to 8.3 and water temperature ranged from 16 to $18.7^{\circ} \mathrm{C}$.

Water chemistry varied among the sites; however, the variations were minimal. Similar to the on-site measurements, concentrations of major ions from laboratory analyses were highest at site 3 ; chloride concentrations at the site ranged from 121 to $129 \mathrm{mg} / \mathrm{L}$, and sodium concentrations ranged from 72.9 to $115 \mathrm{mg} / \mathrm{L}$. Concentrations of chloride and sodium were lowest at site 2, where they ranged from 20.6 to 21.7 and 26.2 to $27.8 \mathrm{mg} / \mathrm{L}$, respectively. Concentrations of chloride and sodium at the Sunshine well were similar to those at site 2. Nutrient concentrations (ammonia, nitrite, nitrate, orthophosphate, and phosphorous) at all sites were less than U.S. Environmental Protection Agency's (USEPA) Maximum Contaminant Levels (MCLs). Concentrations of arsenic and other trace metals also were less than USEPA MCLs at all sites, and concentrations of many trace metals were less than or near laboratory detection limits. With the exception of sulfate concentrations, constituent concentrations did not exceed USEPA Secondary Maximum Contaminant Levels (SMCLs). Sulfate concentrations exceeded the SMCL of $250 \mathrm{mg} / \mathrm{L}$ at all sites and were highest at site 1 (about $385 \mathrm{mg} / \mathrm{L}$ ) - the average concentration at the other sites, including the Sunshine well, was about $255 \mathrm{mg} / \mathrm{L}$. Gross alpha and gross beta radioactivity at the sites ranged from about 4.2 to 11.6 and 1.1 to $4.1 \mathrm{pCi} / \mathrm{L}$, respectively. These counts indicate the likelihood that ground water has interacted with radioactive material, such as uranium, which is a component of some geologic units in the area.

A water sample collected from each site during the constant-rate aquifer tests was analyzed for stable isotopes of oxygen and hydrogen by the USGS Isotope Fractionation Project Laboratory in Reston, Virginia. Stable-isotope ratios determined in this study are reported relative to Vienna Standard Mean Ocean Water (VSMOW). Differences from the standard are expressed by delta notation $(\delta)$ in per mil (\%o):

$$
\partial=\left(\frac{R x-R s t d}{R s t d}\right) 1,000,
$$

where

$$
\begin{aligned}
R x= & \text { ratio of isotopes measured in sample, and } \\
R s t d= & \text { ratio of same isotopes in the standard } \\
& \text { (VSMOW). }
\end{aligned}
$$

Stable-isotope values for the three samples were similar: $\delta^{18} \mathrm{O}$ ranged from -11.34 to -11.07 , and $\delta^{2} \mathrm{H}$ ranged from -82 to -77.9. The ratios of $\delta^{18} \mathrm{O}$ to $\delta^{2} \mathrm{H}$ are similar to those of global meteoric water, indicating no effect from evaporation (Craig, 1961). On the basis of a local stable-isotope/altitude relation (Blasch and others, in press), these values indicate the ground water has received recharge from precipitation occurring at altitudes of about 6,700 to $7,600 \mathrm{ft}$.

The presence of tritium ( 0.02 to 0.18 tritium units, table 6) in water samples indicates the likelihood that ground water at the sites has received at least a small component of recharge since the early 1950s. These data, combined with data and interpretation from future studies, could yield information on ground-water age and flow paths. 


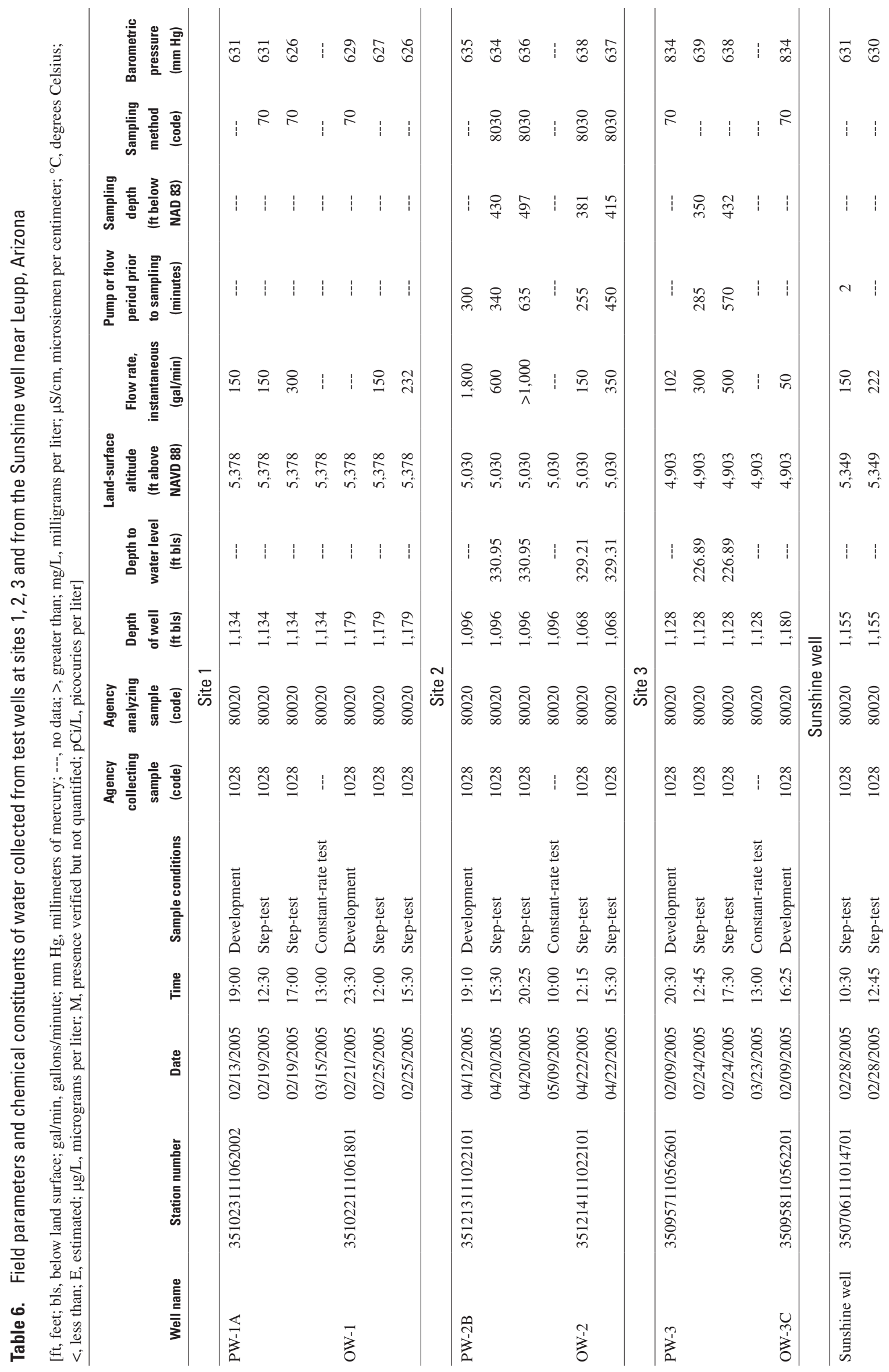




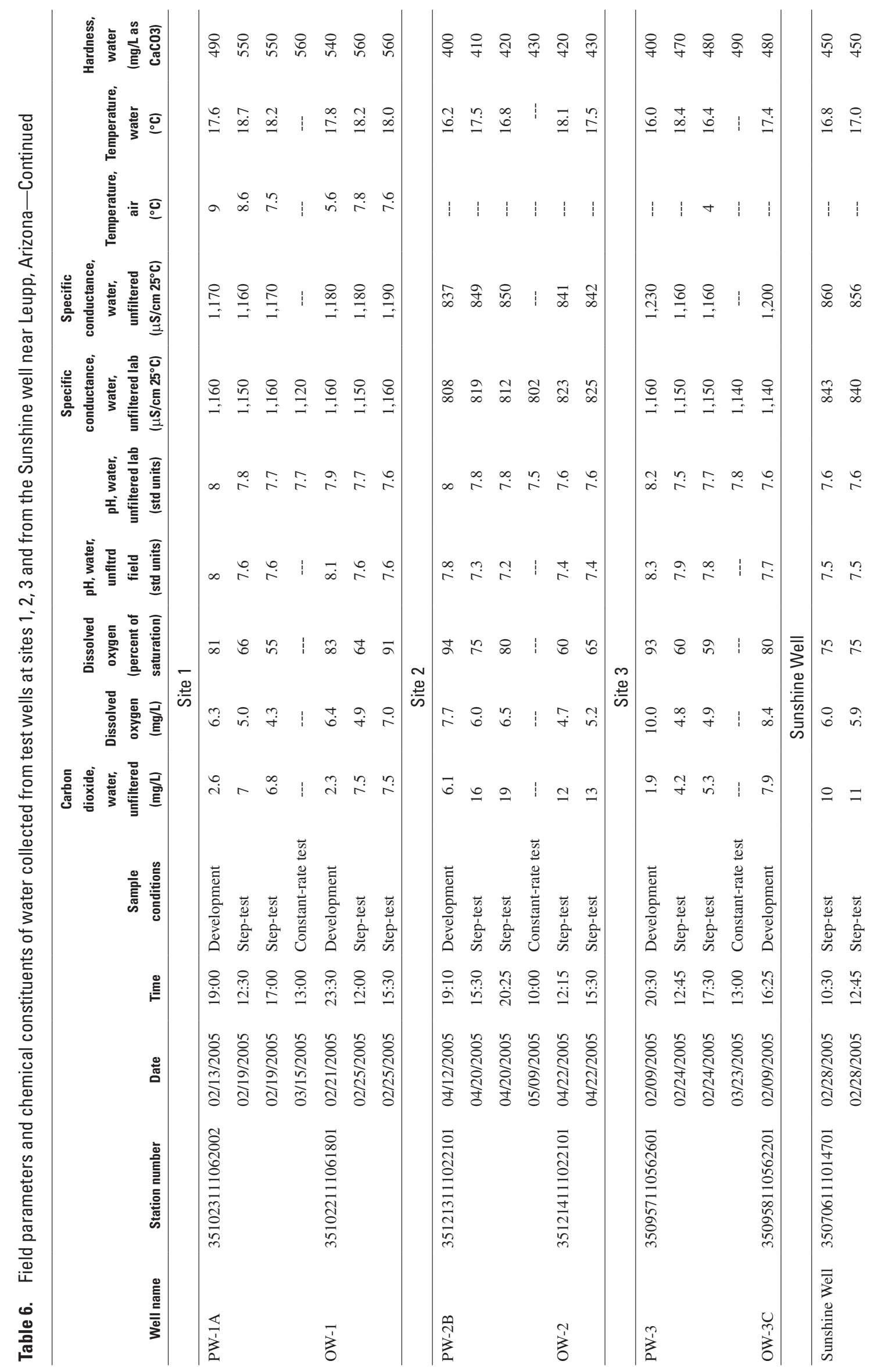




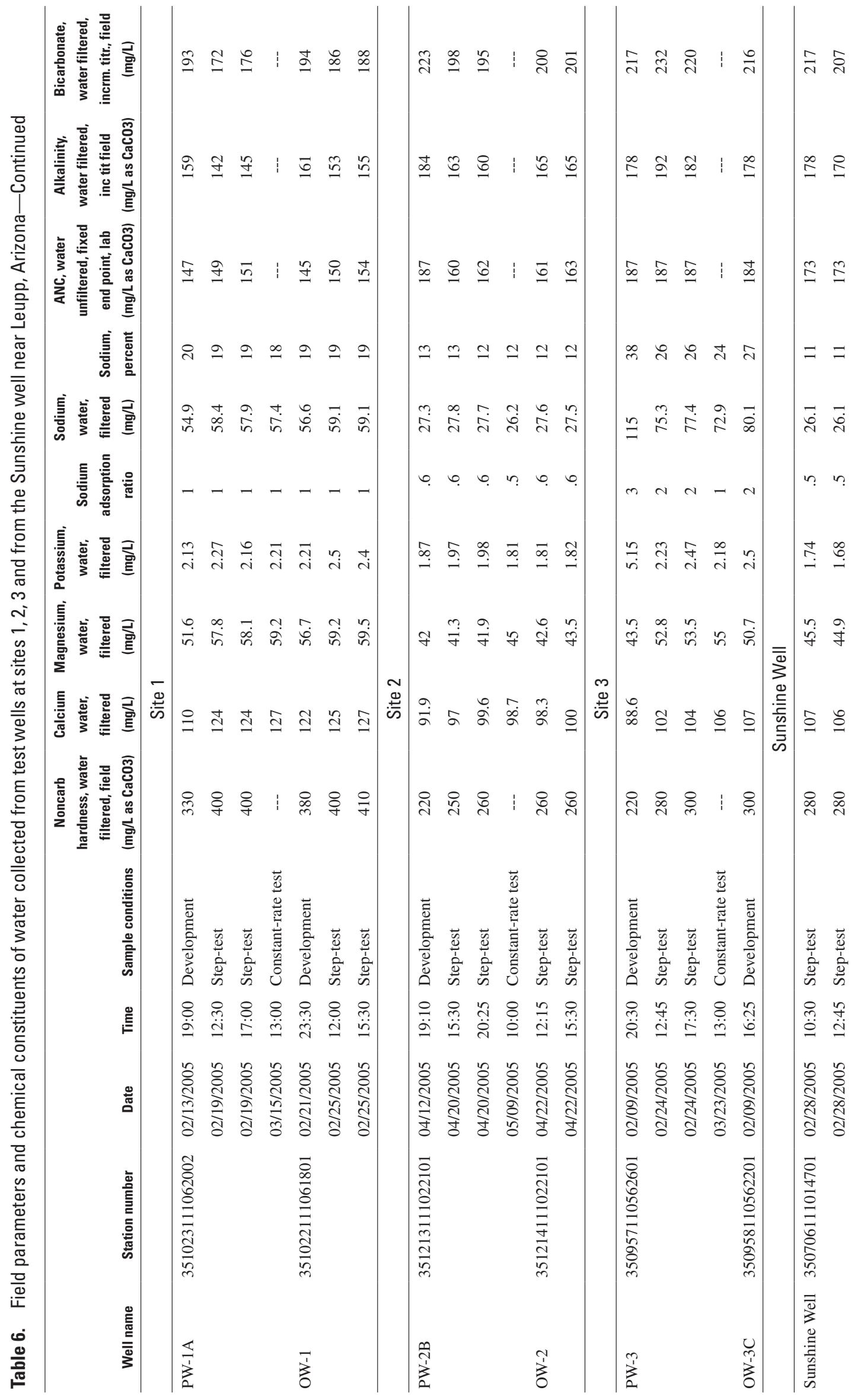




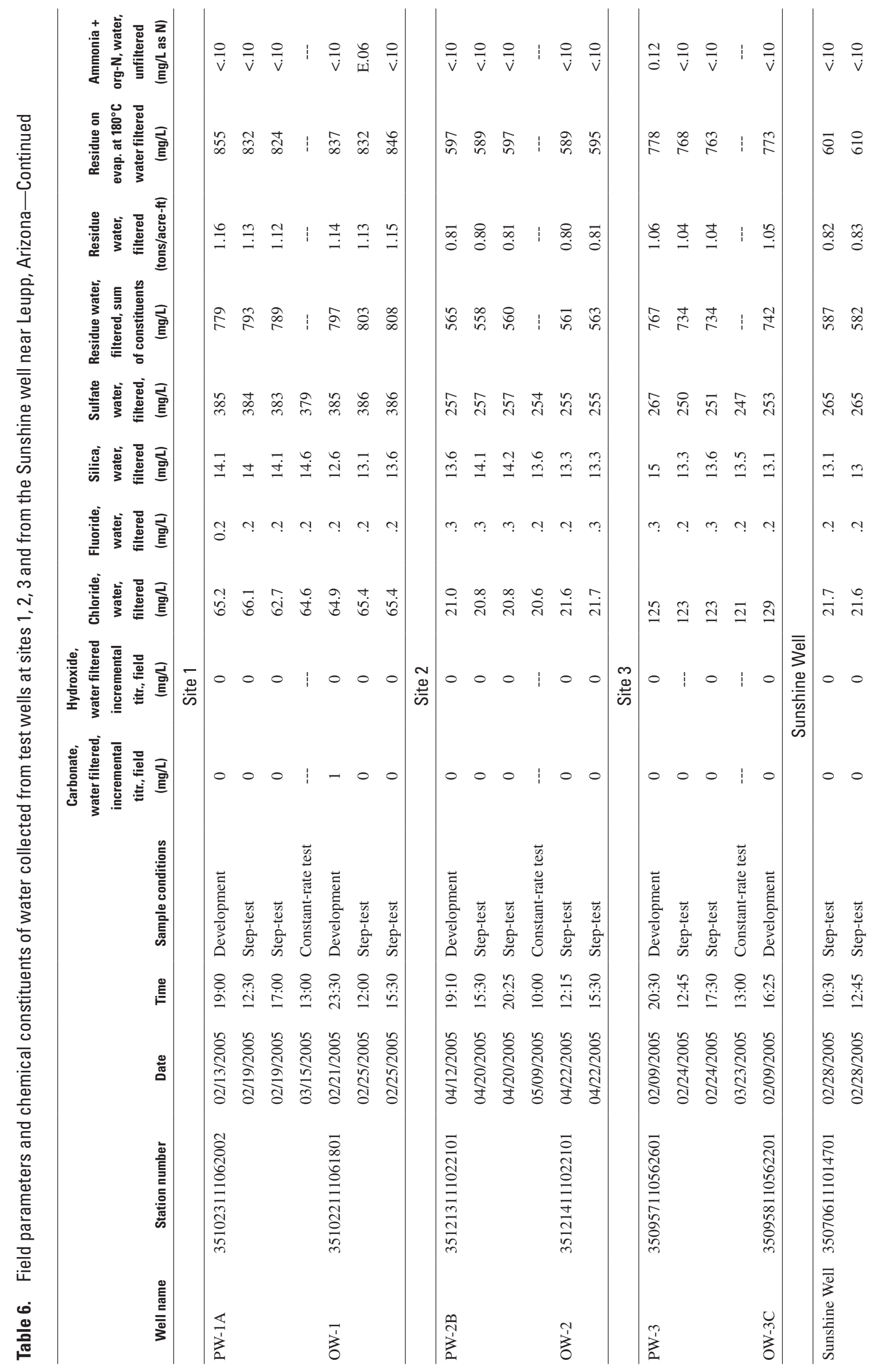




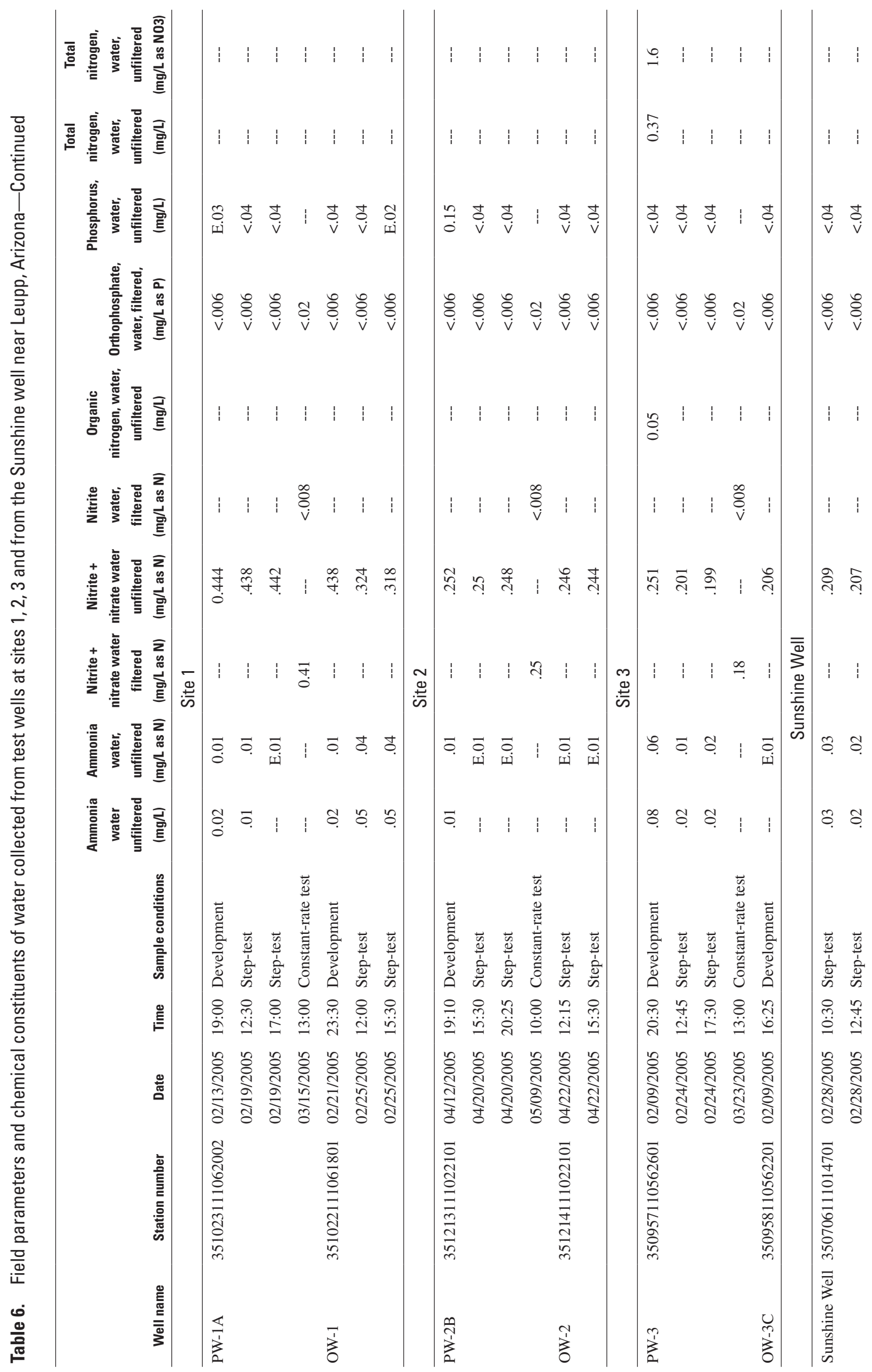




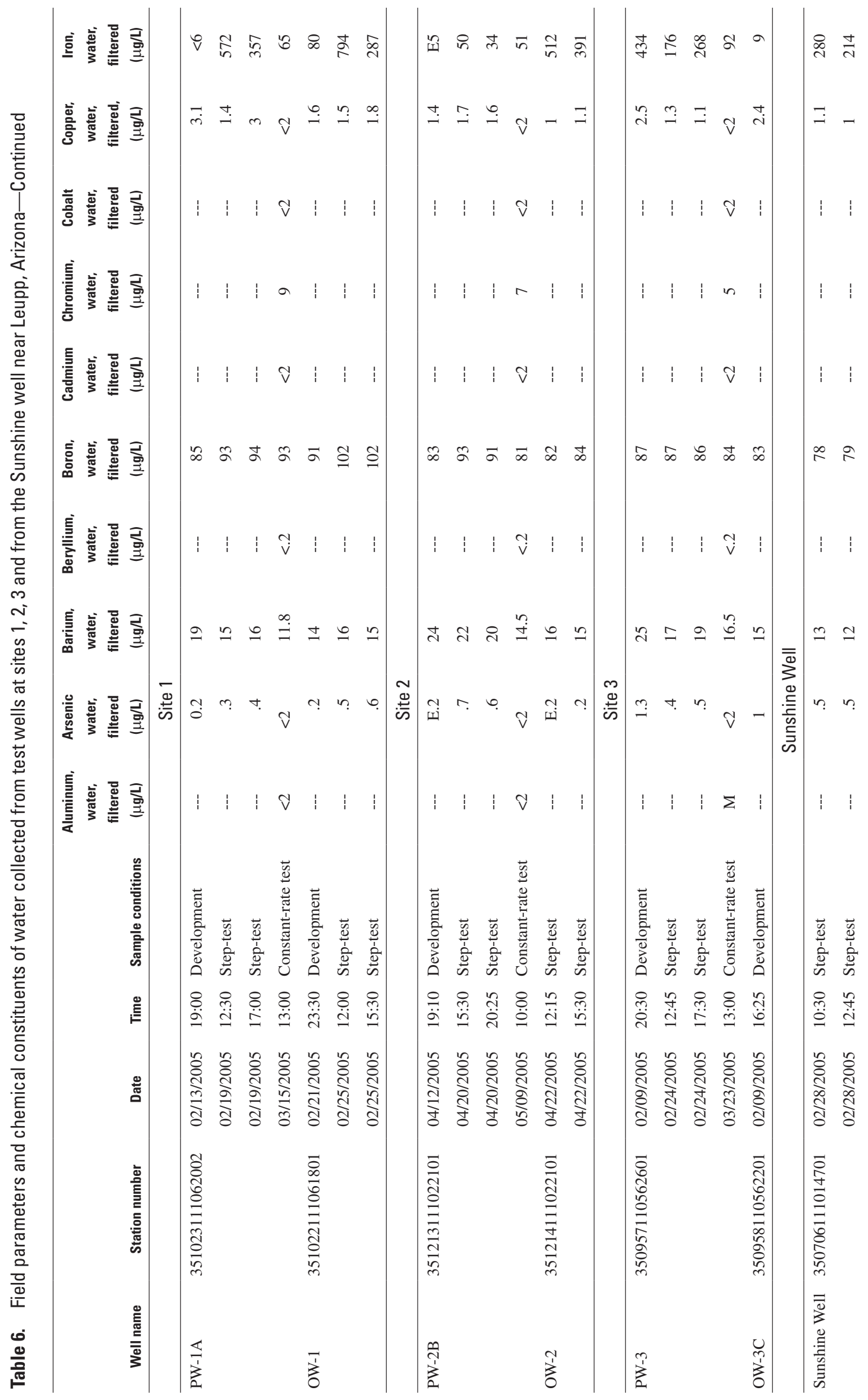




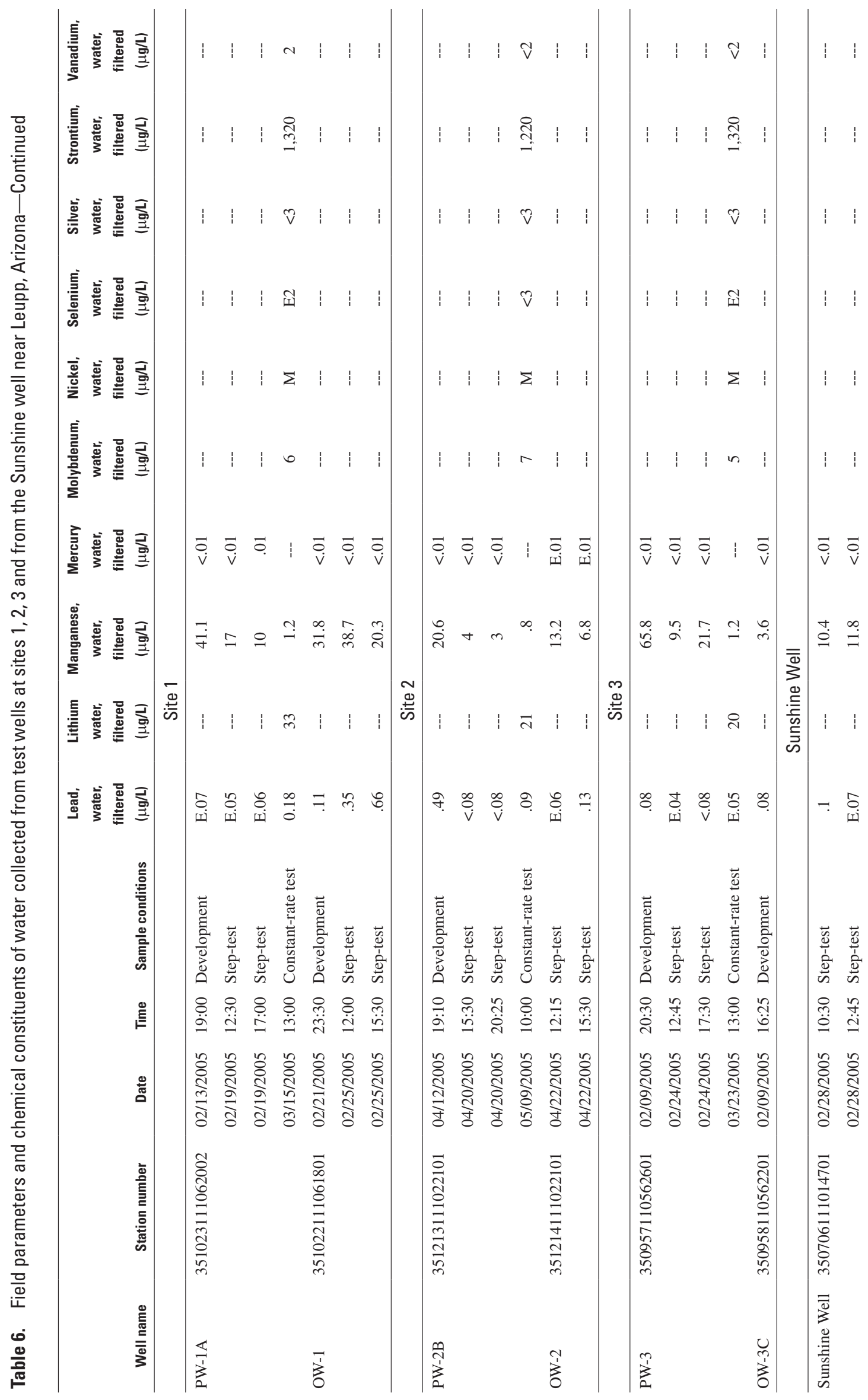




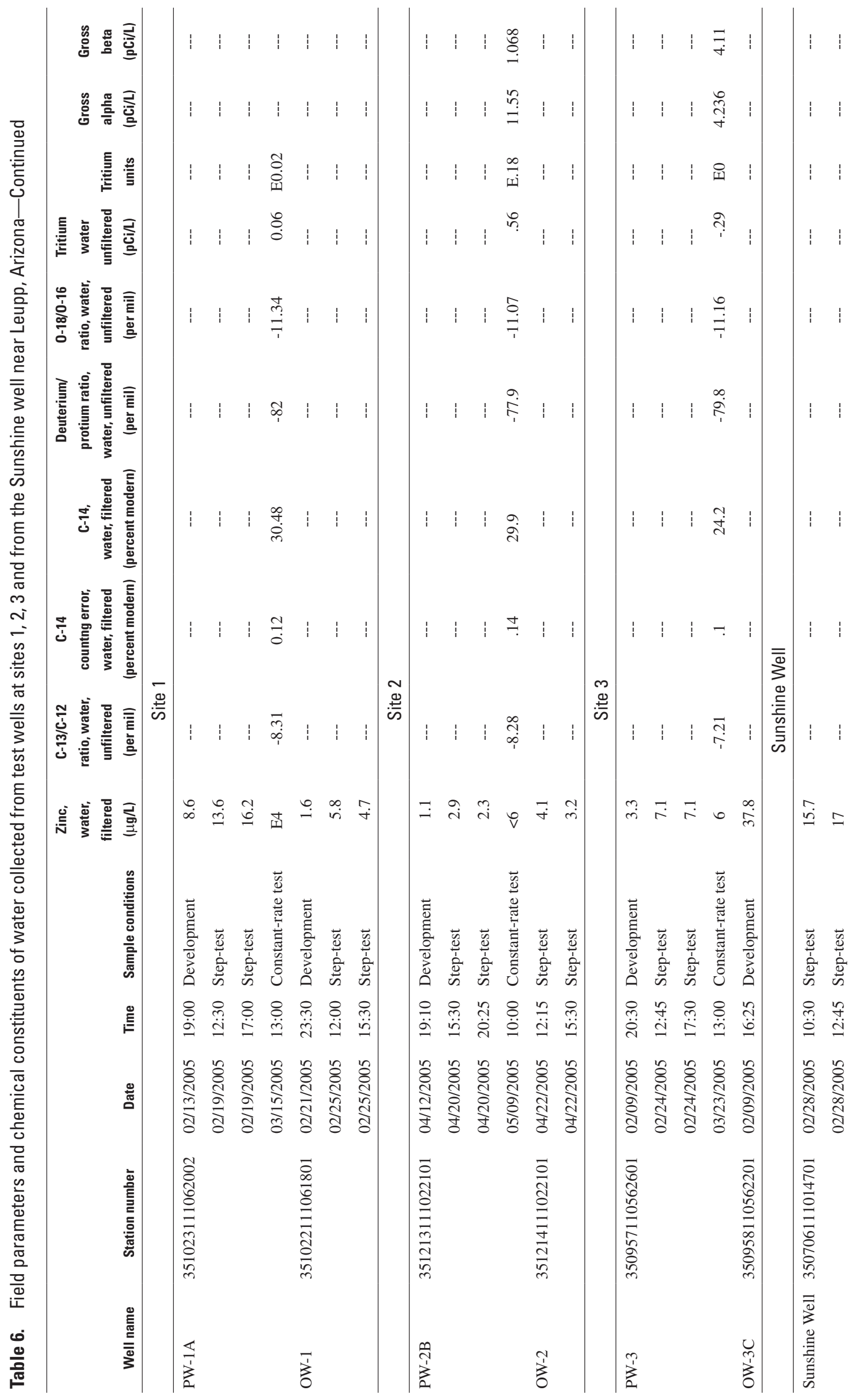




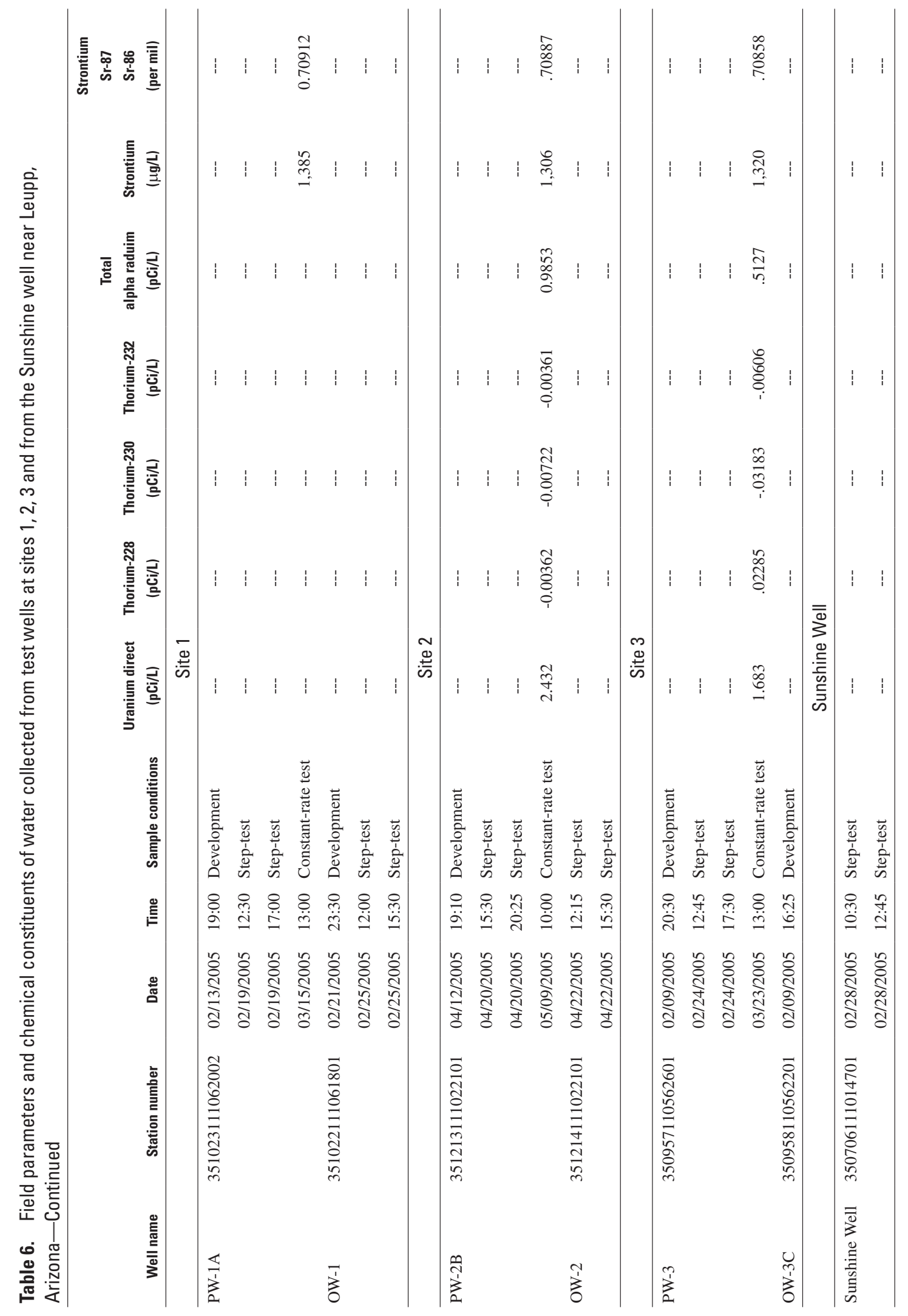




\section{Summary}

The $\mathrm{C}$ aquifer is the most productive aquifer in northern Arizona and provides industry, land owners, businesses, agriculture, and municipalities with a dependable water supply. The areal extent of the aquifer is more than $27,000 \mathrm{mi}^{2}$. Proposed new development of water resources in the area has led to an evaluation of the aquifer by a Federal team comprising personnel from the Bureau of Reclamation (BOR), the U.S. Geological Survey, (USGS), the U.S. Fish and Wildlife Service, the Office of Surface Mining, and Native American tribes. The USGS has been tasked with collection of geologic, hydrologic, and water-chemistry data on the aquifer to determine viability of the aquifer for increased use. The BOR and USGS, therefore, entered into a program to drill test wells at three sites near Leupp, Arizona. Activities included geologic logging of test wells, aquifer tests, and collection and analysis of water-chemistry samples. Rock units penetrated during drilling were, in descending order, the Moenkopi, Kaibab, and Toroweap Formations, the Coconino Sandstone, the Schnebly Hill Formation, and the Upper Supai Formation. Water levels ranged from 226 to $615 \mathrm{ft}$ below land surface and were generally within the Coconino Sandstone. Estimated transmissivity of the aquifer was about 5,400 to $7,000 \mathrm{ft}^{2} / \mathrm{d}$ on the basis of numerical-model analyses of aquifer tests at two of the three sites. Estimated transmissivity at site 2 , determined from analytical and numerical-model methods, ranges from 7,600 to $53,000 \mathrm{ft}^{2} / \mathrm{d}$, but these values are less reliable than those from the other sites. Most of the transmissivity can be attributed to the Coconino Sandstone.

Water quality, based on the analysis of 18 water samples collected at the 3 sites and 2 samples from a nearby abandoned well, generally was good for intended uses. Specific conductance ranged from 837 to $1,230 \mu \mathrm{S} / \mathrm{cm}$ and was lowest at site 2 and highest at site 3 . Concentrations of dissolved chloride and dissolved sodium correlated with specific conductance values and ranged from 20.6 to $129 \mathrm{mg} / \mathrm{L}$ and 26.2 to $115 \mathrm{mg} / \mathrm{L}$, respectively. Trace-metal and nutrient concentrations were below USEPA MCLs at all sites. Sulfate concentrations exceeded the USEPA SMCL at all sites - concentrations were highest at site 3 (about $385 \mathrm{mg} / \mathrm{L}$ ). Average sulfate concentrations at the other sites was about $255 \mathrm{mg} / \mathrm{L}$. The radioactivity in the water indicates the water likely has interacted with radioactive material, such as uranium, which is a component of some geologic units in the area. Stable-isotope values are indicative of water that has received recharge from precipitation occurring at altitudes of about 6,700 to $7,600 \mathrm{ft}$.

\section{References Cited}

Barlow, P.M., and Moench, A.F., 1999, WTAQ-A computer program for calculating drawdowns and estimating hydraulic properties for confined and water-table aquifers: U.S. Geological Survey Water-Resources Investigations Report 99-4225, 74 p.

Bills, D.J., and Flynn, M.E., 2002, Hydrologic data for the Coconino Plateau and adjacent areas, Coconino and Yavapai Counties, Arizona: U.S. Geological Survey Open-File Report 02-265, 27 p.

Bills, D.J., Truini, Margot, Flynn, M.E., Pierce, H.A., Cathings, R.D., and Rymer, M.J., 2000, Hydrogeology of the regional aquifer near Flagstaff, Arizona, 1994-97: U.S. Geological Survey Water-Resources Investigations Report 00-4122, 143 p.

Blakey, R.C., 1990, Stratigraphy and geologic history of Pennsylvanian and Permian rocks, Mogollon Rim region, central Arizona and vicinity: Geological Society of America Bulletin, v. 102, p. 1189-1217.

Blasch, K.W., Hoffmann, J.P., Graser, L.F., Bryson, J.R., and Flint, A.L., in press, Hydrogeology of the upper and middle Verde River watersheds, central Arizona: U.S. Geological Survey Scientific Investigations Report 2005-5198,

Cooley, M.E., Harshbarger, J.W., Akers, J.P., and Hardt, W.F., 1969, Regional hydrology of the Navajo and Hopi Indian Reservations, Arizona, New Mexico, and Utah: U.S. Geological Survey Professional Paper 521-A, 61 p.

Cooper, H.H., and Jacob, C.E., 1946, A generalized graphical method for evaluating formation constants and summarizing well-field history, American Geophysical Union Transactions, v. 27, no. 4, p. 526-534.

Craig, H, 1961, Standard reporting concentrations of deuterium + oxygen-18 in natural waters: Science, v. 133, no. 3467 , p. $1833-1834$.

Halford, K.J., 1992, Incorporating reservoir characteristics for automatic history matching: Baton Rouge, Louisiana State University, Ph.D. dissertation, 150 p.

Harbaugh, A.W., and McDonald, M.G., 1996, Programmer's documentation for MODFLOW-96, an update to the U.S. Geological Survey modular finite difference ground-water flow model: U.S. Geological Survey Open-File Report 96-486, 220 p. 
Hart, R.J., Ward, J.J., Bills, D.J., and Flynn, M.E., 2002, Generalized hydrogeology and ground-water budget for the $\mathrm{C}$ aquifer, Little Colorado River basin and parts of the Verde and Salt River Basins, Arizona and New Mexico: U.S. Geological Survey, Water-Resources Investigations Report 02-4026, 47 p.

Mann, L.J., 1976, Ground-water resources and water use in southern Navajo County, Arizona: Phoenix, Arizona, Arizona Water Commission Bulletin 10, 106 p.

Mann, L.J., and Nemecek, E.A., 1983, Geohydrology and water use in southern Apache County, Arizona: Phoenix, Arizona Department of Water Resources, Bulletin 1, 86 p., 5 plates.

McDonald, M.G., and Harbaugh, A.W., 1988, A modular three-dimensional finite-difference ground-water flow model: U.S. Geological Survey Techniques of WaterResources Investigations, book 6, chapter A1, 576 p.

McGavock, E.J., Anderson, T.W., Moosburner, Otto, and Mann, L.J., 1986, Water resources of southern Coconino County, Arizona: Phoenix, Arizona Department of Water Resources Bulletin 4, 53 p.

McKee, E.D., 1954, Stratigraphy and history of the Moenkopi Formation of Triassic Age: Geological Society of America Memoir 61, $133 \mathrm{p}$.

McKee, E.D., 1982, The Supai Group of the Grand Canyon: U.S. Geological Survey Professional Paper 1173, 504 p.

Sorauf, J.E., and Billingsley, G.H., 1991, Members of the Toroweap and Kaibab Formations, Lower Permian, northern Arizona and southwestern Utah: The Mountain Geologist, v. 28 , no. 1 , p. 9-24.

U.S. Geological Survey, variously dated, National field manual for the collection of water-quality data: U.S. Geological Survey Techniques of Water-Resources Investigations, book 9, chaps. A1-A9, available online at http://pubs. water.usgs.gov/twri9A. [Chapter updates and revisions are ongoing and are summarized at http://water.usgs.gov/owq/ FieldManual/mastererrata.html] 


\section{Appendix}

Table A. Filtered drawdown data for wells during constant-rate aquifer test at site 1 near Leupp, Arizona

[Constant-rate aquifer test started at 14:00 on March 3, 2005. Pumping rate during the test ranged from 386 to 412 gallons per minute and averaged about 400 gallons per minute]

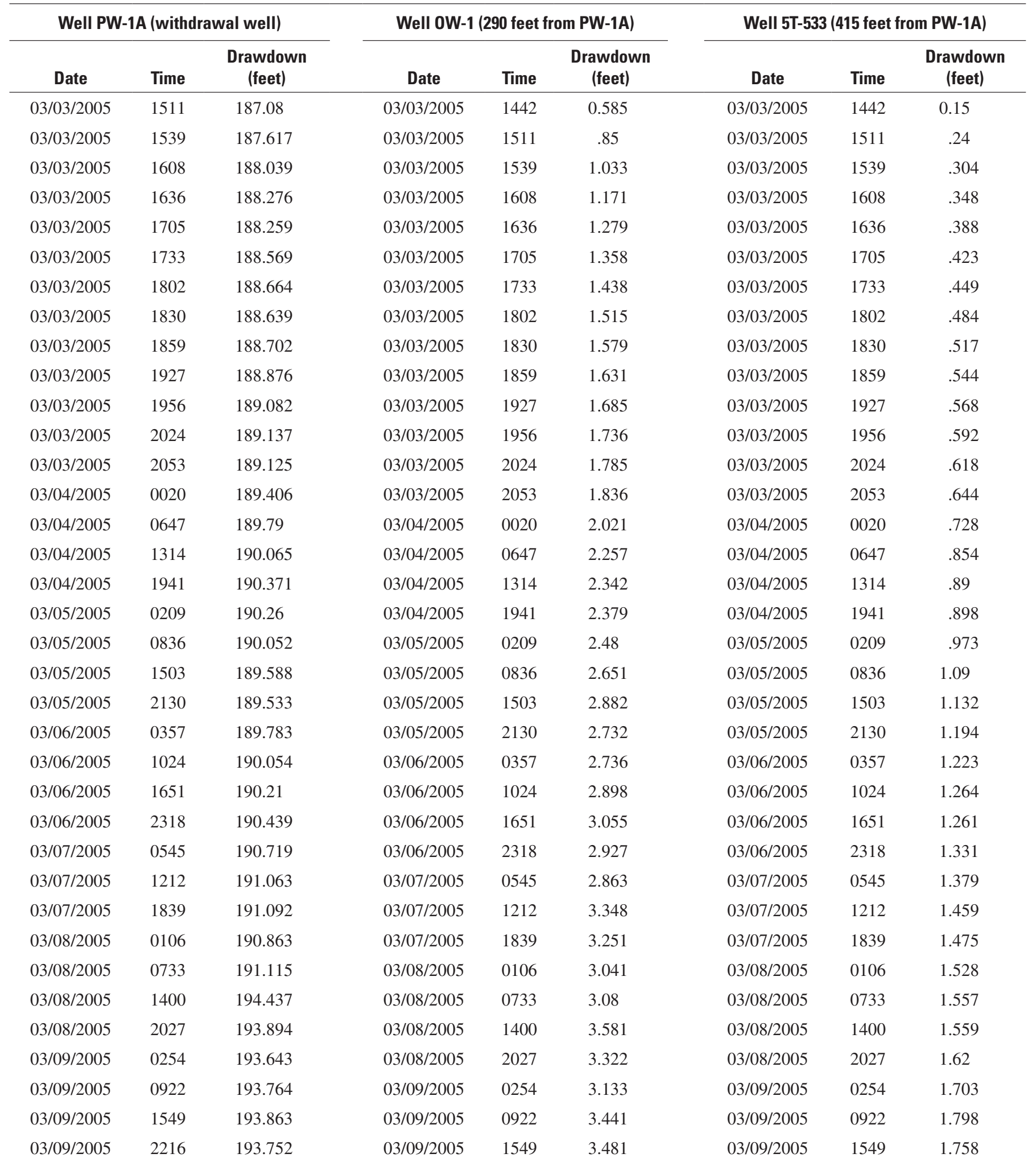


Table A. Filtered drawdown data for wells during constant-rate aquifer test at site 1, near Leupp, Arizona-Continued

\begin{tabular}{|c|c|c|c|c|c|c|c|c|}
\hline \multicolumn{3}{|c|}{ Well PW-1A (withdrawal well) } & \multicolumn{3}{|c|}{ Well 0W-1 (290 feet from PW-1A) } & \multicolumn{3}{|c|}{ Well 5T-533 (415 feet from PW-1A) } \\
\hline Date & Time & $\begin{array}{l}\text { Drawdown } \\
\text { (feet) }\end{array}$ & Date & Time & $\begin{array}{c}\text { Drawdown } \\
\text { (feet) }\end{array}$ & Date & Time & $\begin{array}{l}\text { Drawdown } \\
\text { (feet) }\end{array}$ \\
\hline 03/10/2005 & 1110 & 193.899 & $3 / 10 / 2005$ & 0443 & 3.279 & 03/10/2005 & 0443 & 1.715 \\
\hline 03/10/2005 & 1737 & 201.627 & $3 / 10 / 2005$ & 1110 & 3.326 & 03/10/2005 & 1110 & 1.733 \\
\hline 03/11/2005 & 0631 & 202.829 & $3 / 11 / 2005$ & 0004 & 3.448 & $03 / 11 / 2005$ & 0004 & 1.836 \\
\hline $03 / 11 / 2005$ & 1258 & 203.103 & $3 / 11 / 2005$ & 0631 & 3.55 & $03 / 11 / 2005$ & 0631 & 1.929 \\
\hline $03 / 11 / 2005$ & 1925 & 202.999 & $3 / 11 / 2005$ & 1258 & 3.593 & $03 / 11 / 2005$ & 1258 & 1.972 \\
\hline $03 / 12 / 2005$ & 0205 & 202.917 & $3 / 11 / 2005$ & 1925 & 3.53 & $03 / 11 / 2005$ & 1925 & 1.903 \\
\hline 03/13/2005 & 0540 & 202.8 & $3 / 12 / 2005$ & 2246 & 3.433 & $03 / 12 / 2005$ & 2246 & 1.81 \\
\hline 03/13/2005 & 1233 & 202.924 & $3 / 13 / 2005$ & 0540 & 3.454 & $03 / 13 / 2005$ & 0540 & 1.834 \\
\hline 03/13/2005 & 1927 & 202.957 & $3 / 13 / 2005$ & 1233 & 3.466 & 03/13/2005 & 1233 & 1.849 \\
\hline 03/14/2005 & 0220 & 203.029 & $3 / 13 / 2005$ & 1927 & 3.476 & 03/13/2005 & 1927 & 1.865 \\
\hline 03/14/2005 & 0914 & 203.187 & $3 / 14 / 2005$ & 0220 & 3.577 & $03 / 14 / 2005$ & 0220 & 1.962 \\
\hline $03 / 14 / 2005$ & 1607 & 203.175 & $3 / 14 / 2005$ & 0914 & 3.653 & $03 / 14 / 2005$ & 0914 & 2.034 \\
\hline 03/14/2005 & 2301 & 203.165 & $3 / 14 / 2005$ & 1607 & 3.671 & 03/14/2005 & 1607 & 2.049 \\
\hline $03 / 15 / 2005$ & 0554 & 203.074 & $3 / 14 / 2005$ & 2301 & 3.745 & $03 / 14 / 2005$ & 2301 & 2.124 \\
\hline 03/15/2005 & 1248 & 204.208 & $3 / 15 / 2005$ & 0554 & 3.824 & $03 / 15 / 2005$ & 0554 & 2.202 \\
\hline $03 / 17 / 2005$ & 0609 & 203.001 & $3 / 16 / 2005$ & 2316 & 3.943 & 03/16/2005 & 2316 & 2.312 \\
\hline 03/17/2005 & 1303 & 202.884 & $3 / 17 / 2005$ & 0609 & 3.947 & $03 / 17 / 2005$ & 0609 & 2.315 \\
\hline 03/17/2005 & 1840 & 1.967 & $3 / 17 / 2005$ & 1303 & 3.85 & 03/17/2005 & 1303 & 2.271 \\
\hline 03/17/2005 & 2003 & 1.624 & $3 / 17 / 2005$ & 1922 & 3.077 & 03/17/2005 & 1922 & 1.938 \\
\hline 03/17/2005 & 2126 & 1.456 & $3 / 18 / 2005$ & 0053 & 2.002 & 03/18/2005 & 0053 & 1.607 \\
\hline 03/17/2005 & 2249 & 1.375 & $3 / 18 / 2005$ & 0624 & 1.717 & 03/18/2005 & 0624 & 1.478 \\
\hline 03/18/2005 & 0012 & 1.29 & $3 / 18 / 2005$ & 1155 & 1.595 & 03/18/2005 & 1155 & 1.438 \\
\hline 03/18/2005 & 0135 & 1.194 & $3 / 18 / 2005$ & 1726 & 1.498 & 03/18/2005 & 1726 & 1.383 \\
\hline 03/18/2005 & 0258 & 1.131 & $3 / 18 / 2005$ & 2258 & 1.469 & 03/18/2005 & 2258 & 1.383 \\
\hline 03/18/2005 & 0421 & 1.065 & $3 / 19 / 2005$ & 0429 & 1.406 & 03/19/2005 & 0429 & 1.338 \\
\hline 03/18/2005 & 0544 & 1.025 & $3 / 19 / 2005$ & 1000 & 1.397 & $03 / 19 / 2005$ & 1000 & 1.347 \\
\hline 03/18/2005 & 0707 & 1.006 & $3 / 19 / 2005$ & 1531 & 1.353 & 03/19/2005 & 1531 & 1.314 \\
\hline 03/18/2005 & 0831 & .986 & $3 / 19 / 2005$ & 2102 & 1.349 & 03/19/2005 & 2102 & 1.325 \\
\hline 03/18/2005 & 0954 & .965 & $3 / 20 / 2005$ & 0233 & 1.295 & 03/20/2005 & 0233 & 1.276 \\
\hline $03 / 18 / 2005$ & 1117 & .945 & $3 / 20 / 2005$ & 0804 & 1.227 & 03/20/2005 & 0804 & 1.222 \\
\hline
\end{tabular}


Table A. Filtered drawdown data for wells during constant-rate aquifer test at site 1, near Leupp, Arizona-Continued

\begin{tabular}{|c|c|c|c|c|c|c|c|c|}
\hline \multicolumn{3}{|c|}{ Well PW-1A (withdrawal well) } & \multicolumn{3}{|c|}{ Well OW-1 (290 feet from PW-1A) } & \multicolumn{3}{|c|}{ Well 5T-533 (415 feet from PW-1A) } \\
\hline Date & Time & $\begin{array}{l}\text { Drawdown } \\
\text { (feet) }\end{array}$ & Date & Time & $\begin{array}{l}\text { Drawdown } \\
\text { (feet) }\end{array}$ & Date & Time & $\begin{array}{l}\text { Drawdown } \\
\text { (feet) }\end{array}$ \\
\hline 03/18/2005 & 1240 & 0.911 & $03 / 20 / 2005$ & 1335 & 1.204 & $03 / 20 / 2005$ & 1335 & 1.211 \\
\hline 03/18/2005 & 1403 & .883 & $03 / 20 / 2005$ & 1906 & 1.232 & $03 / 20 / 2005$ & 1906 & 1.238 \\
\hline 03/18/2005 & 1526 & .86 & $03 / 21 / 2005$ & 0037 & 1.272 & $03 / 21 / 2005$ & 0037 & 1.283 \\
\hline $03 / 18 / 2005$ & 1649 & .84 & $03 / 21 / 2005$ & 0608 & 1.262 & $03 / 21 / 2005$ & 0608 & 1.276 \\
\hline 03/18/2005 & 1812 & .825 & $03 / 21 / 2005$ & 1139 & 1.262 & $03 / 21 / 2005$ & 1139 & 1.283 \\
\hline 03/18/2005 & 1935 & .825 & $03 / 21 / 2005$ & 1710 & 1.214 & $03 / 21 / 2005$ & 1710 & 1.236 \\
\hline 03/19/2005 & 0717 & .744 & $03 / 21 / 2005$ & 2241 & 1.266 & $03 / 21 / 2005$ & 2241 & 1.287 \\
\hline 03/20/2005 & 0517 & .599 & $03 / 22 / 2005$ & 0412 & 1.221 & $03 / 22 / 2005$ & 0412 & 1.243 \\
\hline $03 / 21 / 2005$ & 0318 & .566 & $03 / 22 / 2005$ & 1349 & 1.113 & $03 / 22 / 2005$ & 1349 & 1.143 \\
\hline $03 / 22 / 2005$ & 0118 & .508 & $03 / 23 / 2005$ & 0334 & .906 & $03 / 23 / 2005$ & 0334 & .949 \\
\hline 03/22/2005 & 2318 & .229 & 03/23/2005 & 1718 & .889 & $03 / 23 / 2005$ & 1718 & .951 \\
\hline 03/23/2005 & 2119 & .191 & $03 / 24 / 2005$ & 0702 & 1.018 & $03 / 24 / 2005$ & 0702 & 1.076 \\
\hline 03/24/2005 & 1919 & .275 & $03 / 24 / 2005$ & 2047 & 1.029 & $03 / 24 / 2005$ & 2047 & 1.091 \\
\hline $03 / 25 / 2005$ & 1719 & .257 & $03 / 25 / 2005$ & 1031 & 1.024 & $03 / 25 / 2005$ & 1031 & 1.087 \\
\hline 03/26/2005 & 1520 & .379 & $03 / 26 / 2005$ & 0015 & 1.054 & $03 / 26 / 2005$ & 0015 & 1.124 \\
\hline \multirow[t]{3}{*}{$03 / 27 / 2005$} & 1320 & .285 & $03 / 26 / 2005$ & 1359 & 1.179 & 03/26/2005 & 1359 & 1.248 \\
\hline & & & $03 / 27 / 2005$ & 0344 & 1.229 & $03 / 27 / 2005$ & 0344 & 1.294 \\
\hline & & & 03/27/2005 & 1728 & 1.055 & $03 / 27 / 2005$ & 1728 & 1.122 \\
\hline
\end{tabular}


Table B. Filtered drawdown data for wells during constant-rate aquifer test at site 2, near Leupp, Arizona

[Constant-rate aquifer test started at 1200 on April 26, 2005. Pumping rate during the test averaged 745 gallons per minute]

\begin{tabular}{|c|c|c|c|c|c|c|c|c|}
\hline \multicolumn{3}{|c|}{$\begin{array}{l}\text { Well 0W-2A (deep) } \\
\text { (402 ft from PW-2B) }\end{array}$} & \multicolumn{3}{|c|}{$\begin{array}{l}\text { Well 0W-2A (middle) } \\
\text { (402 ft from PW-2B) }\end{array}$} & \multicolumn{3}{|c|}{$\begin{array}{c}\text { Well OW-2A (shallow) } \\
\text { (402 ft from PW-2B) }\end{array}$} \\
\hline Date & Time & $\begin{array}{c}\text { Drawdown } \\
\text { (feet) }\end{array}$ & Date & Time & $\begin{array}{c}\text { Drawdown } \\
\text { (feet) }\end{array}$ & Date & Time & $\begin{array}{c}\text { Drawdown } \\
\text { (feet) }\end{array}$ \\
\hline $04 / 26 / 2005$ & 1221 & 0.092 & $4 / 26 / 2005$ & 1221 & 0.063 & $4 / 26 / 2005$ & 1221 & 0.041 \\
\hline $04 / 26 / 2005$ & 1303 & .248 & $4 / 26 / 2005$ & 1303 & 0.245 & $4 / 26 / 2005$ & 1303 & .209 \\
\hline $04 / 26 / 2005$ & 1428 & .266 & $4 / 26 / 2005$ & 1428 & 0.318 & $4 / 26 / 2005$ & 1428 & .292 \\
\hline $04 / 26 / 2005$ & 1510 & .249 & $4 / 26 / 2005$ & 1510 & 0.339 & $4 / 26 / 2005$ & 1510 & .311 \\
\hline $04 / 26 / 2005$ & 1553 & .246 & $4 / 26 / 2005$ & 1553 & 0.357 & $4 / 26 / 2005$ & 1553 & .336 \\
\hline $04 / 26 / 2005$ & 1635 & .247 & $4 / 26 / 2005$ & 1635 & 0.371 & $4 / 26 / 2005$ & 1635 & .354 \\
\hline $04 / 26 / 2005$ & 2251 & .398 & $4 / 26 / 2005$ & 2251 & 0.435 & $4 / 26 / 2005$ & 2251 & .416 \\
\hline $04 / 27 / 2005$ & 627 & .403 & $4 / 27 / 2005$ & 0627 & 0.42 & $4 / 27 / 2005$ & 627 & .402 \\
\hline $04 / 27 / 2005$ & 1402 & .414 & $4 / 27 / 2005$ & 1402 & 0.421 & $4 / 27 / 2005$ & 1402 & .401 \\
\hline $04 / 27 / 2005$ & 2137 & .443 & $4 / 27 / 2005$ & 2137 & 0.509 & $4 / 27 / 2005$ & 2137 & .495 \\
\hline $04 / 28 / 2005$ & 0513 & .444 & $4 / 28 / 2005$ & 0513 & 0.473 & $4 / 28 / 2005$ & 513 & .46 \\
\hline $04 / 28 / 2005$ & 1248 & .474 & $4 / 28 / 2005$ & 1248 & 0.451 & $4 / 28 / 2005$ & 1248 & .436 \\
\hline $04 / 28 / 2005$ & 2023 & .475 & $4 / 28 / 2005$ & 2023 & 0.553 & $4 / 28 / 2005$ & 2023 & .547 \\
\hline $04 / 29 / 2005$ & 359 & .503 & $4 / 29 / 2005$ & 359 & 0.532 & $4 / 29 / 2005$ & 359 & .527 \\
\hline $04 / 29 / 2005$ & 1134 & .546 & $4 / 29 / 2005$ & 1134 & 0.522 & $4 / 29 / 2005$ & 1134 & .516 \\
\hline 05/01/2005 & 906 & .564 & $5 / 1 / 2005$ & 906 & 0.573 & $5 / 1 / 2005$ & 906 & .571 \\
\hline 05/01/2005 & 2004 & .584 & $5 / 1 / 2005$ & 2004 & 0.614 & $5 / 1 / 2005$ & 2004 & .612 \\
\hline $05 / 02 / 2005$ & 1024 & .597 & $5 / 2 / 2005$ & 1024 & 0.606 & $5 / 2 / 2005$ & 1024 & .606 \\
\hline 05/03/2005 & 045 & .606 & $5 / 3 / 2005$ & 045 & 0.636 & $5 / 3 / 2005$ & 045 & .636 \\
\hline 05/03/2005 & 1505 & .618 & $5 / 3 / 2005$ & 1505 & 0.63 & $5 / 3 / 2005$ & 1505 & .625 \\
\hline $05 / 04 / 2005$ & 525 & .661 & $5 / 4 / 2005$ & 0525 & 0.693 & $5 / 4 / 2005$ & 525 & .693 \\
\hline 05/04/2005 & 1946 & .615 & $5 / 4 / 2005$ & 1946 & 0.649 & $5 / 4 / 2005$ & 1946 & .651 \\
\hline 05/05/2005 & 1006 & .616 & $5 / 5 / 2005$ & 1006 & 0.644 & $5 / 5 / 2005$ & 1006 & .646 \\
\hline 05/06/2005 & 027 & .627 & $5 / 6 / 2005$ & 027 & 0.643 & $5 / 6 / 2005$ & 027 & .644 \\
\hline 05/06/2005 & 1447 & .647 & $5 / 6 / 2005$ & 1447 & 0.667 & $5 / 6 / 2005$ & 1447 & .67 \\
\hline 05/07/2005 & 507 & .685 & $5 / 7 / 2005$ & 507 & 0.688 & $5 / 7 / 2005$ & 507 & .69 \\
\hline 05/07/2005 & 1928 & .661 & $5 / 7 / 2005$ & 1928 & 0.706 & $5 / 7 / 2005$ & 1928 & .711 \\
\hline 05/08/2005 & 948 & .684 & $5 / 8 / 2005$ & 0948 & 0.707 & $5 / 8 / 2005$ & 948 & .71 \\
\hline 05/09/2005 & 009 & 0.69 & $5 / 9 / 2005$ & 0009 & 0.722 & 5/9/2005 & 009 & .726 \\
\hline
\end{tabular}


Table B. Filtered drawdown data for wells during constant-rate aquifer test at site 2, near Leupp, Arizona-Continued

\begin{tabular}{|c|c|c|c|c|c|c|c|c|}
\hline \multicolumn{3}{|c|}{$\begin{array}{c}\text { Well OW-2A (deep)-Continued } \\
\text { (402 ft from PW-2B) }\end{array}$} & \multicolumn{3}{|c|}{$\begin{array}{c}\text { Well OW-2A (middle)-Continued } \\
\text { (402 ft from PW-2B) }\end{array}$} & \multicolumn{3}{|c|}{$\begin{array}{c}\text { Well OW-2A (shallow)—Continued } \\
\text { (402 ft from PW-2B) }\end{array}$} \\
\hline Date & Time & $\begin{array}{l}\text { Drawdown } \\
\text { (feet) }\end{array}$ & Date & Time & $\begin{array}{l}\text { Drawdown } \\
\text { (feet) }\end{array}$ & Date & Time & $\begin{array}{l}\text { Drawdown } \\
\text { (feet) }\end{array}$ \\
\hline 05/09/2005 & 1429 & 0.76 & $05 / 09 / 2005$ & 1429 & 0.708 & $05 / 09 / 2005$ & 1429 & 0.712 \\
\hline 05/10/2005 & 0449 & .768 & $05 / 10 / 2005$ & 0449 & .692 & $05 / 10 / 2005$ & 0449 & .698 \\
\hline 05/10/2005 & 1326 & .422 & $05 / 10 / 2005$ & 1326 & .428 & $05 / 10 / 2005$ & 1326 & .47 \\
\hline 05/10/2005 & 1513 & .302 & $05 / 10 / 2005$ & 1513 & .372 & $05 / 10 / 2005$ & 1513 & .4 \\
\hline 05/10/2005 & 1700 & .276 & $05 / 10 / 2005$ & 1700 & .388 & $05 / 10 / 2005$ & 1700 & .41 \\
\hline 05/10/2005 & 1848 & .315 & 05/10/2005 & 1848 & .405 & 05/10/2005 & 1848 & .428 \\
\hline 05/10/2005 & 2035 & .361 & $05 / 10 / 2005$ & 2035 & .415 & $05 / 10 / 2005$ & 2035 & .44 \\
\hline 05/10/2005 & 2222 & .382 & $05 / 10 / 2005$ & 2222 & .396 & $05 / 10 / 2005$ & 2222 & .414 \\
\hline $05 / 11 / 2005$ & 0010 & .36 & $05 / 11 / 2005$ & 0010 & .369 & $05 / 11 / 2005$ & 0010 & .383 \\
\hline $05 / 11 / 2005$ & 0157 & .32 & $05 / 11 / 2005$ & 0157 & .34 & $05 / 11 / 2005$ & 0157 & .356 \\
\hline $05 / 11 / 2005$ & 0344 & .28 & $05 / 11 / 2005$ & 0344 & .323 & $05 / 11 / 2005$ & 0344 & .339 \\
\hline $05 / 11 / 2005$ & 0532 & .281 & $05 / 11 / 2005$ & 0532 & .319 & $05 / 11 / 2005$ & 0532 & .328 \\
\hline $05 / 11 / 2005$ & 1430 & .285 & $05 / 11 / 2005$ & 1430 & .306 & $05 / 11 / 2005$ & 1430 & .319 \\
\hline $05 / 12 / 2005$ & 0640 & .282 & $05 / 12 / 2005$ & 0640 & .282 & $05 / 12 / 2005$ & 0640 & .29 \\
\hline $05 / 12 / 2005$ & 2250 & .245 & $05 / 12 / 2005$ & 2250 & .291 & $05 / 12 / 2005$ & 2250 & .3 \\
\hline $05 / 13 / 2005$ & 1500 & .233 & $05 / 13 / 2005$ & 1500 & .253 & $05 / 13 / 2005$ & 1500 & .261 \\
\hline $05 / 14 / 2005$ & 2320 & .172 & $05 / 14 / 2005$ & 2320 & .209 & $05 / 14 / 2005$ & 2320 & .217 \\
\hline $05 / 15 / 2005$ & 1530 & .143 & $05 / 15 / 2005$ & 1530 & .164 & $05 / 15 / 2005$ & 1530 & .171 \\
\hline 05/16/2005 & 0740 & .101 & $05 / 16 / 2005$ & 0740 & .115 & $05 / 16 / 2005$ & 0740 & .122 \\
\hline 05/16/2005 & 2350 & .063 & $05 / 16 / 2005$ & 2350 & .09 & $05 / 16 / 2005$ & 2350 & .098 \\
\hline $05 / 17 / 2005$ & 1600 & .098 & $05 / 17 / 2005$ & 1600 & .12 & $05 / 17 / 2005$ & 1600 & .127 \\
\hline \multicolumn{3}{|c|}{ Well PW-2B (withdrawal well) } & \multicolumn{3}{|c|}{$\begin{array}{c}\text { Well 5M-94 } \\
\text { (251 ft from PW-2B) }\end{array}$} & \multicolumn{3}{|c|}{$\begin{array}{c}\text { Well 0W-2 } \\
\text { (178 ft from PW-2B) }\end{array}$} \\
\hline Date & Time & $\begin{array}{l}\text { Drawdown } \\
\text { (feet) }\end{array}$ & Date & Time & $\begin{array}{l}\text { Drawdown } \\
\text { (feet) }\end{array}$ & Date & Time & $\begin{array}{c}\text { Drawdown } \\
\text { (feet) }\end{array}$ \\
\hline $04 / 26 / 2005$ & 1428 & 93.703 & 05/04/2005 & 0530 & .718 & $04 / 26 / 2005$ & 1203 & 1.767 \\
\hline $04 / 26 / 2005$ & 1510 & 93.612 & $05 / 06 / 2005$ & 0014 & .718 & $04 / 26 / 2005$ & 1206 & 2.538 \\
\hline $04 / 26 / 2005$ & 1553 & 93.616 & $05 / 08 / 2005$ & 0448 & .77 & $04 / 26 / 2005$ & 1209 & 2.97 \\
\hline $04 / 26 / 2005$ & 1635 & 93.6 & $05 / 10 / 2005$ & 1236 & .594 & $04 / 26 / 2005$ & 1211 & 3.256 \\
\hline $04 / 26 / 2005$ & 1718 & 93.613 & $05 / 10 / 2005$ & 1247 & .556 & $04 / 26 / 2005$ & 1214 & 3.437 \\
\hline $04 / 26 / 2005$ & 1800 & 93.703 & $05 / 10 / 2005$ & 1301 & .526 & $04 / 26 / 2005$ & 1217 & 3.56 \\
\hline $04 / 26 / 2005$ & 1842 & 93.782 & $05 / 10 / 2005$ & 1319 & .498 & $04 / 26 / 2005$ & 1219 & 3.688 \\
\hline $04 / 26 / 2005$ & 2251 & 94.236 & 05/10/2005 & 1343 & .481 & $04 / 26 / 2005$ & 1222 & 3.703 \\
\hline $04 / 27 / 2005$ & 0627 & 94.427 & $05 / 10 / 2005$ & 1415 & .466 & $04 / 26 / 2005$ & 1224 & 3.755 \\
\hline $04 / 27 / 2005$ & 1402 & 94.057 & $05 / 10 / 2005$ & 1455 & .454 & $04 / 26 / 2005$ & 1329 & 3.934 \\
\hline $04 / 27 / 2005$ & 2137 & 94.478 & $05 / 10 / 2005$ & 1548 & .451 & $04 / 26 / 2005$ & 1535 & 4.048 \\
\hline $04 / 28 / 2005$ & 0513 & 95.035 & 05/10/2005 & 1656 & .45 & $04 / 26 / 2005$ & 1741 & 4.064 \\
\hline $04 / 28 / 2005$ & 1248 & 94.805 & $05 / 10 / 2005$ & 1825 & .452 & $04 / 26 / 2005$ & 1947 & 4.071 \\
\hline $04 / 28 / 2005$ & 2023 & 93.889 & 05/10/2005 & 2021 & .456 & $04 / 26 / 2005$ & 2153 & 4.029 \\
\hline
\end{tabular}


Table B. Filtered drawdown data for wells during constant-rate aquifer test at site 2, near Leupp, Arizona—Continued

\begin{tabular}{|c|c|c|c|c|c|c|c|c|}
\hline \multicolumn{3}{|c|}{$\begin{array}{c}\text { Well OW-2 } \\
\text { (178 ft from PW-2B)-Continued }\end{array}$} & \multicolumn{3}{|c|}{$\begin{array}{c}\text { Well OW-2 } \\
\text { (178 ft from PW-2B)—Continued }\end{array}$} & \multicolumn{3}{|c|}{$\begin{array}{c}\text { Well OW-2 } \\
\text { (178 ft from PW-2B }- \text {-Continued }\end{array}$} \\
\hline Date & Time & $\begin{array}{l}\text { Drawdown } \\
\text { (feet) }\end{array}$ & Date & Time & $\begin{array}{l}\text { Drawdown } \\
\text { (feet) }\end{array}$ & Date & Time & $\begin{array}{l}\text { Drawdown } \\
\text { (feet) }\end{array}$ \\
\hline $04 / 26 / 2005$ & 2359 & 3.97 & 05/03/2005 & 1246 & 4.081 & $05 / 12 / 2005$ & 0017 & .236 \\
\hline $04 / 27 / 2005$ & 0205 & 3.952 & $05 / 03 / 2005$ & 2254 & 4.073 & $05 / 12 / 2005$ & 0502 & .283 \\
\hline $04 / 27 / 2005$ & 0411 & 4.005 & $05 / 04 / 2005$ & 0902 & 4.096 & $05 / 12 / 2005$ & 0947 & .377 \\
\hline $04 / 27 / 2005$ & 0617 & 4.088 & 05/04/2005 & 1910 & 4.108 & $05 / 12 / 2005$ & 1433 & .302 \\
\hline $04 / 27 / 2005$ & 0823 & 4.127 & $05 / 05 / 2005$ & 0518 & 4.089 & $05 / 12 / 2005$ & 1918 & .29 \\
\hline $04 / 27 / 2005$ & 1029 & 4.096 & $05 / 05 / 2005$ & 1526 & 4.059 & 05/13/2005 & 0003 & .236 \\
\hline $04 / 27 / 2005$ & 1236 & 4.042 & $05 / 06 / 2005$ & 0135 & 4.073 & 05/13/2005 & 0448 & .248 \\
\hline $04 / 27 / 2005$ & 1442 & 4.013 & 05/06/2005 & 1143 & 4.06 & 05/13/2005 & 0933 & .359 \\
\hline $04 / 27 / 2005$ & 1648 & 4.035 & $05 / 06 / 2005$ & 2151 & 4.121 & $05 / 13 / 2005$ & 1419 & .288 \\
\hline $04 / 27 / 2005$ & 1854 & 4.065 & 05/07/2005 & 0759 & 4.11 & 05/13/2005 & 1904 & .258 \\
\hline $04 / 28 / 2005$ & 0101 & 3.991 & 05/07/2005 & 1807 & 4.091 & 05/13/2005 & 2349 & .198 \\
\hline $04 / 28 / 2005$ & 1109 & 4.06 & 05/08/2005 & 0415 & 4.144 & $05 / 14 / 2005$ & 0434 & .196 \\
\hline $04 / 28 / 2005$ & 2117 & 3.998 & 05/08/2005 & 1423 & 4.099 & $05 / 14 / 2005$ & 0919 & .308 \\
\hline $04 / 29 / 2005$ & 0725 & 4.021 & 05/09/2005 & 0031 & 4.086 & $05 / 14 / 2005$ & 1531 & .237 \\
\hline $04 / 29 / 2005$ & 1733 & 4.093 & 05/09/2005 & 1039 & 4.16 & $05 / 14 / 2005$ & 2309 & .172 \\
\hline $04 / 30 / 2005$ & 0341 & 3.992 & $05 / 09 / 2005$ & 2047 & 4.116 & $05 / 15 / 2005$ & 0647 & .196 \\
\hline $04 / 30 / 2005$ & 1349 & 4.1 & 05/10/2005 & 0655 & 4.116 & $05 / 15 / 2005$ & 1424 & .199 \\
\hline $04 / 30 / 2005$ & 2357 & 4.007 & 05/10/2005 & 1946 & .378 & 05/15/2005 & 2202 & .137 \\
\hline $05 / 01 / 2005$ & 1006 & 4.121 & $05 / 11 / 2005$ & 0031 & .294 & $05 / 16 / 2005$ & 0540 & .086 \\
\hline $05 / 01 / 2005$ & 2014 & 4.122 & $05 / 11 / 2005$ & 0516 & .348 & $05 / 16 / 2005$ & 1318 & .137 \\
\hline $05 / 02 / 2005$ & 0622 & 4.062 & $05 / 11 / 2005$ & 1001 & .407 & $05 / 16 / 2005$ & 2056 & .072 \\
\hline $05 / 02 / 2005$ & 1630 & 4.051 & $05 / 11 / 2005$ & 1446 & .324 & $05 / 17 / 2005$ & 0434 & .037 \\
\hline 05/03/2005 & 0238 & 4.004 & $05 / 11 / 2005$ & 1932 & .305 & & & \\
\hline
\end{tabular}


Table C. Filtered drawdown data for wells during constant-rate aquifer test at site 3, near Leupp, Arizona

[The aquifer test at site 3 included two pumping periods and two recovery periods. The first pumping period extended from $1300 \mathrm{hr}$ on February 26 through March 5, 2005, at rate of about 795 gallons per minute. The second pumping period was between March 11 and March 25, 2005, at a rate of 775 gallons per minute. Recovery was measured between the two pumping periods and after the second pumping period]

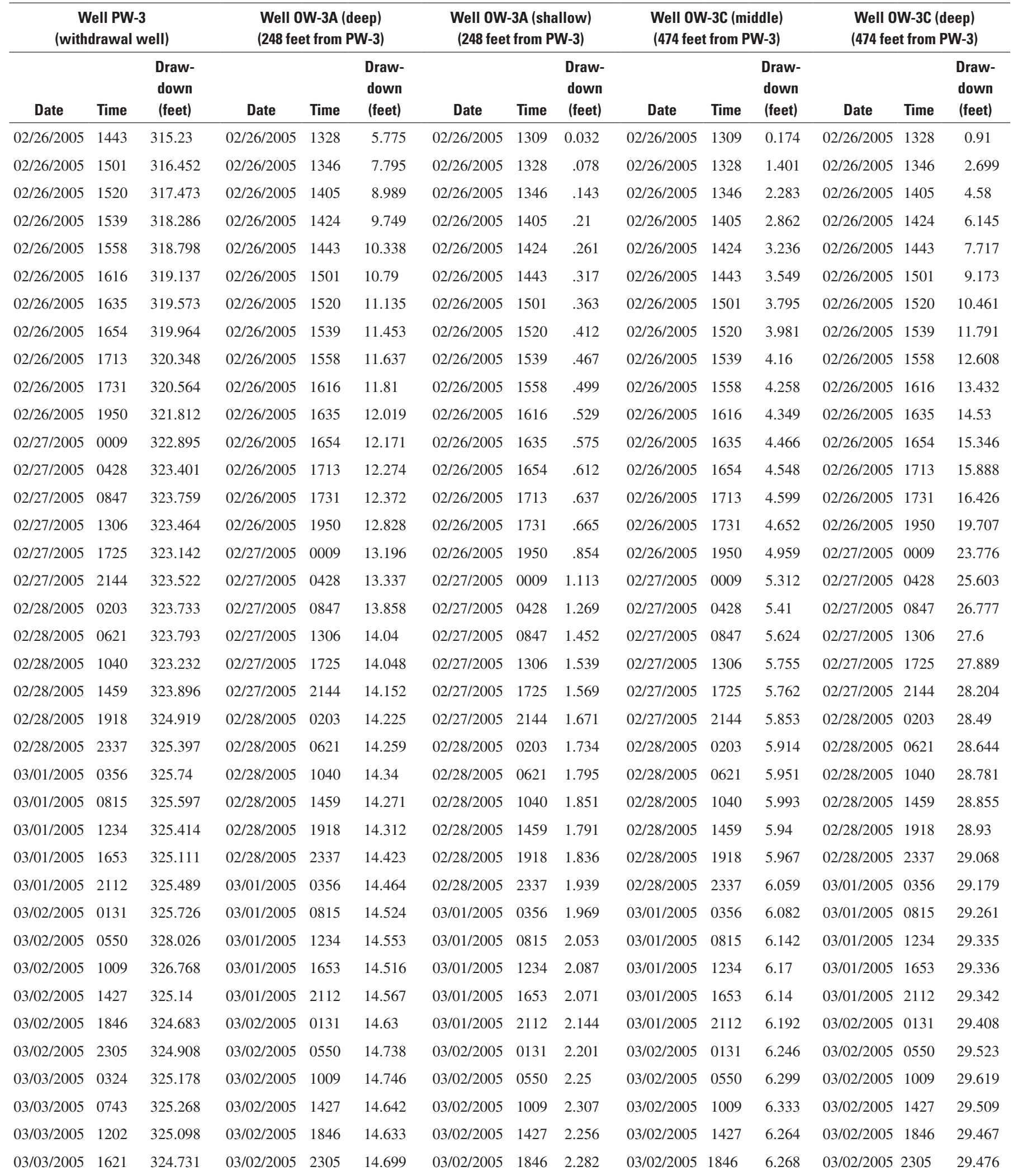


Table C. Filtered drawdown data for wells during constant-rate aquifer test at site 3, near Leupp, Arizona—Continued

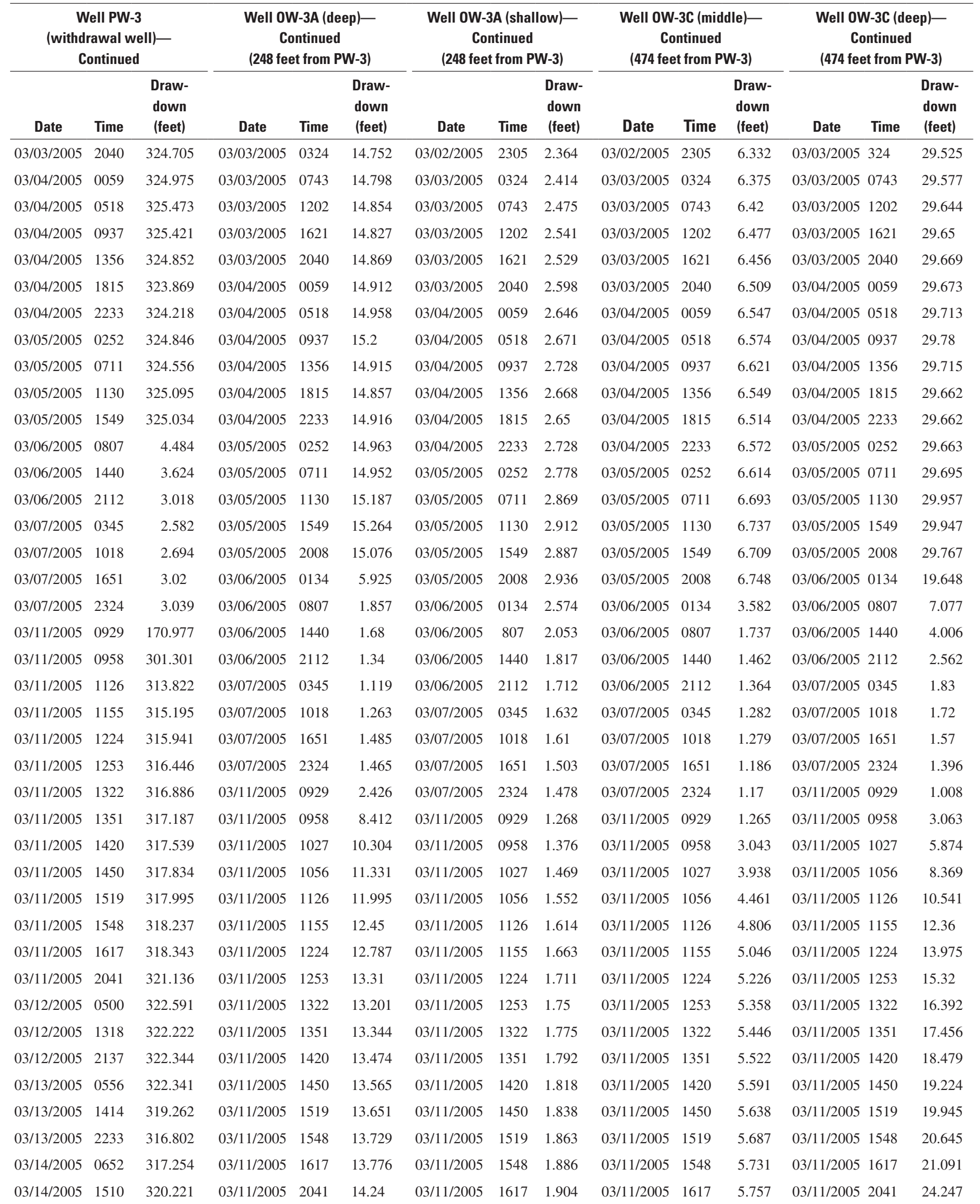


Table C. Filtered drawdown data for wells during constant-rate aquifer test at site 3, near Leupp, Arizona—Continued

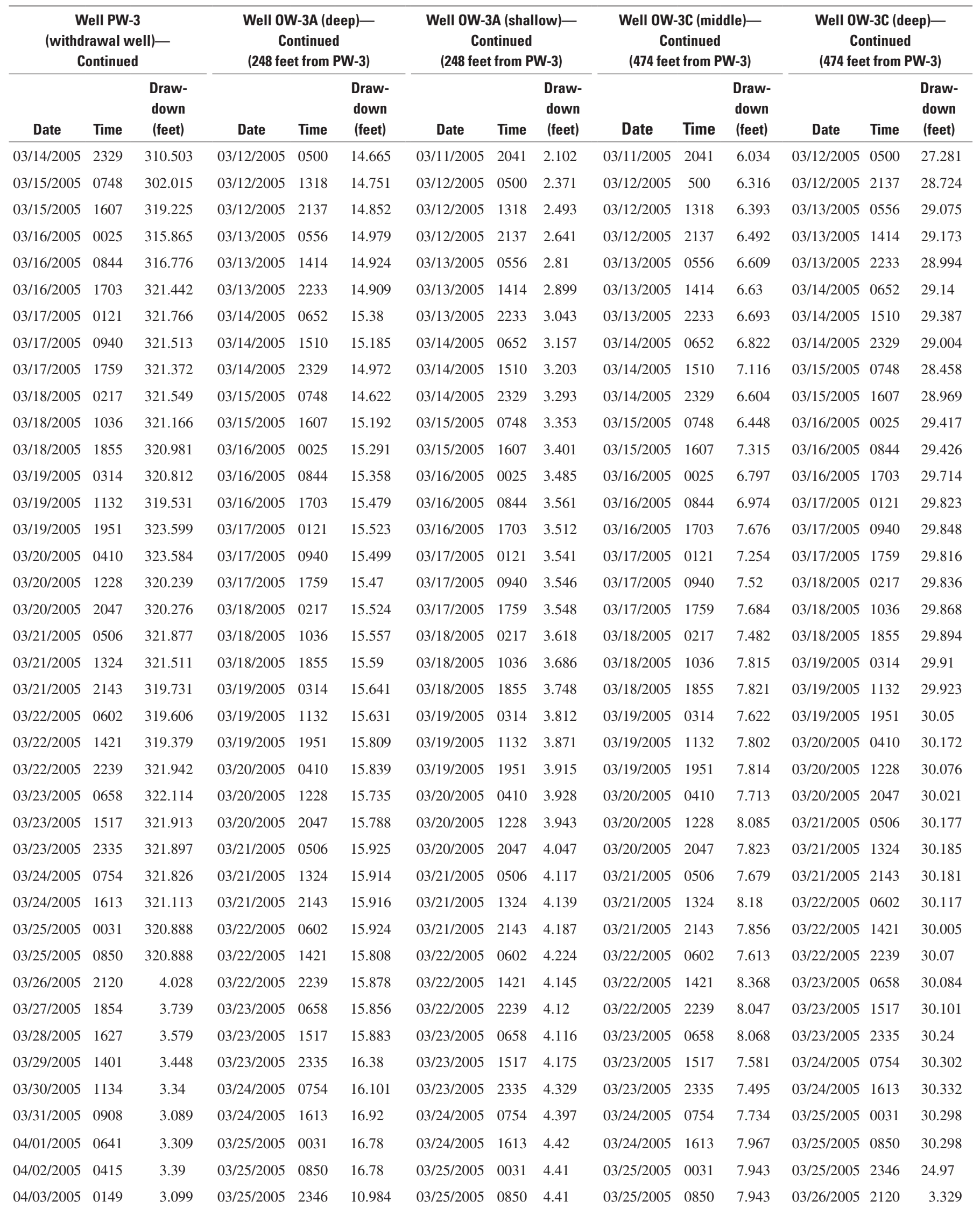


Table C. Filtered drawdown data for wells during constant-rate aquifer test at site 3, near Leupp, Arizona-Continued

\begin{tabular}{|c|c|c|c|c|c|c|c|c|c|c|c|c|c|c|}
\hline \multicolumn{3}{|c|}{$\begin{array}{c}\text { Well PW-3 } \\
\text { (withdrawal well)_- } \\
\text { Continued }\end{array}$} & \multicolumn{3}{|c|}{$\begin{array}{l}\text { Well OW-3A (deep)- } \\
\text { Continued } \\
\text { (248 feet from PW-3) }\end{array}$} & \multicolumn{3}{|c|}{$\begin{array}{c}\text { Well OW-3A (shallow)- } \\
\text { Continued } \\
\text { (248 feet from PW-3) }\end{array}$} & \multicolumn{3}{|c|}{$\begin{array}{c}\text { Well OW-3C (middle)- } \\
\text { Continued } \\
\text { (474 feet from PW-3) }\end{array}$} & \multicolumn{3}{|c|}{$\begin{array}{l}\text { Well OW-3C (deep)- } \\
\text { Continued } \\
\text { (474 feet from PW-3) }\end{array}$} \\
\hline Date & Time & $\begin{array}{l}\text { Draw- } \\
\text { down } \\
\text { (feet) }\end{array}$ & Date & Time & $\begin{array}{l}\text { Draw- } \\
\text { down } \\
\text { (feet) }\end{array}$ & Date & Time & $\begin{array}{l}\text { Draw- } \\
\text { down } \\
\text { (feet) }\end{array}$ & Date & Time & $\begin{array}{l}\text { Draw- } \\
\text { down } \\
\text { (feet) }\end{array}$ & Date & Time & $\begin{array}{l}\text { Draw- } \\
\text { down } \\
\text { (feet) }\end{array}$ \\
\hline 04/03/2005 & 2322 & 3.241 & $03 / 26 / 2005$ & 2120 & 2.635 & $03 / 25 / 2005$ & 2346 & 4.241 & $03 / 25 / 2005$ & 2346 & 6.234 & $03 / 27 / 2005$ & 1854 & 2.079 \\
\hline $04 / 05 / 2005$ & 1829 & 3.102 & $03 / 28 / 2005$ & 1627 & 1.855 & $03 / 27 / 2005$ & 1854 & 2.803 & $03 / 27 / 2005$ & 1854 & 2.381 & $03 / 29 / 2005$ & 1401 & 1.451 \\
\hline 04/06/2005 & 1603 & 2.856 & $03 / 29 / 2005$ & 1401 & 1.858 & $03 / 28 / 2005$ & 1627 & 2.412 & $03 / 28 / 2005$ & 1627 & 1.94 & $03 / 30 / 2005$ & 1134 & 1.495 \\
\hline \multirow[t]{8}{*}{ 04/07/2005 } & 1337 & 2.51 & $03 / 30 / 2005$ & 1134 & 1.891 & $03 / 29 / 2005$ & 1401 & 2.391 & $03 / 29 / 2005$ & 1401 & 1.834 & $03 / 31 / 2005$ & 0908 & 1.646 \\
\hline & & & $03 / 31 / 2005$ & 0908 & 2.023 & $03 / 30 / 2005$ & 1134 & 2.38 & $03 / 30 / 2005$ & 1134 & 1.865 & $04 / 01 / 2005$ & 0641 & 1.71 \\
\hline & & & $04 / 03 / 2005$ & 2322 & 1.523 & $04 / 03 / 2005$ & 0149 & 1.925 & $04 / 03 / 2005$ & 0149 & 1.538 & $04 / 04 / 2005$ & 2056 & 1.255 \\
\hline & & & $04 / 04 / 2005$ & 2056 & 1.562 & $04 / 03 / 2005$ & 2322 & 1.845 & $04 / 03 / 2005$ & 2322 & 1.471 & $04 / 05 / 2005$ & 1829 & 1.505 \\
\hline & & & $04 / 05 / 2005$ & 1829 & 1.765 & $04 / 04 / 2005$ & 2056 & 1.894 & $04 / 04 / 2005$ & 2056 & 1.515 & $04 / 06 / 2005$ & 1603 & 1.49 \\
\hline & & & $04 / 06 / 2005$ & 1603 & 1.69 & $04 / 05 / 2005$ & 1829 & 2.045 & $04 / 05 / 2005$ & 1829 & 1.708 & $04 / 07 / 2005$ & 1337 & 1.268 \\
\hline & & & $04 / 07 / 2005$ & 1337 & 1.466 & $04 / 06 / 2005$ & 1603 & 1.925 & $04 / 06 / 2005$ & 1603 & 1.623 & & & \\
\hline & & & & & & $04 / 07 / 2005$ & 1337 & 1.697 & $04 / 07 / 2005$ & 1337 & 1.396 & & & \\
\hline
\end{tabular}


Table C. Filtered drawdown data for wells during constant-rate aquifer test at site 3, near Leupp, Arizona-Continued

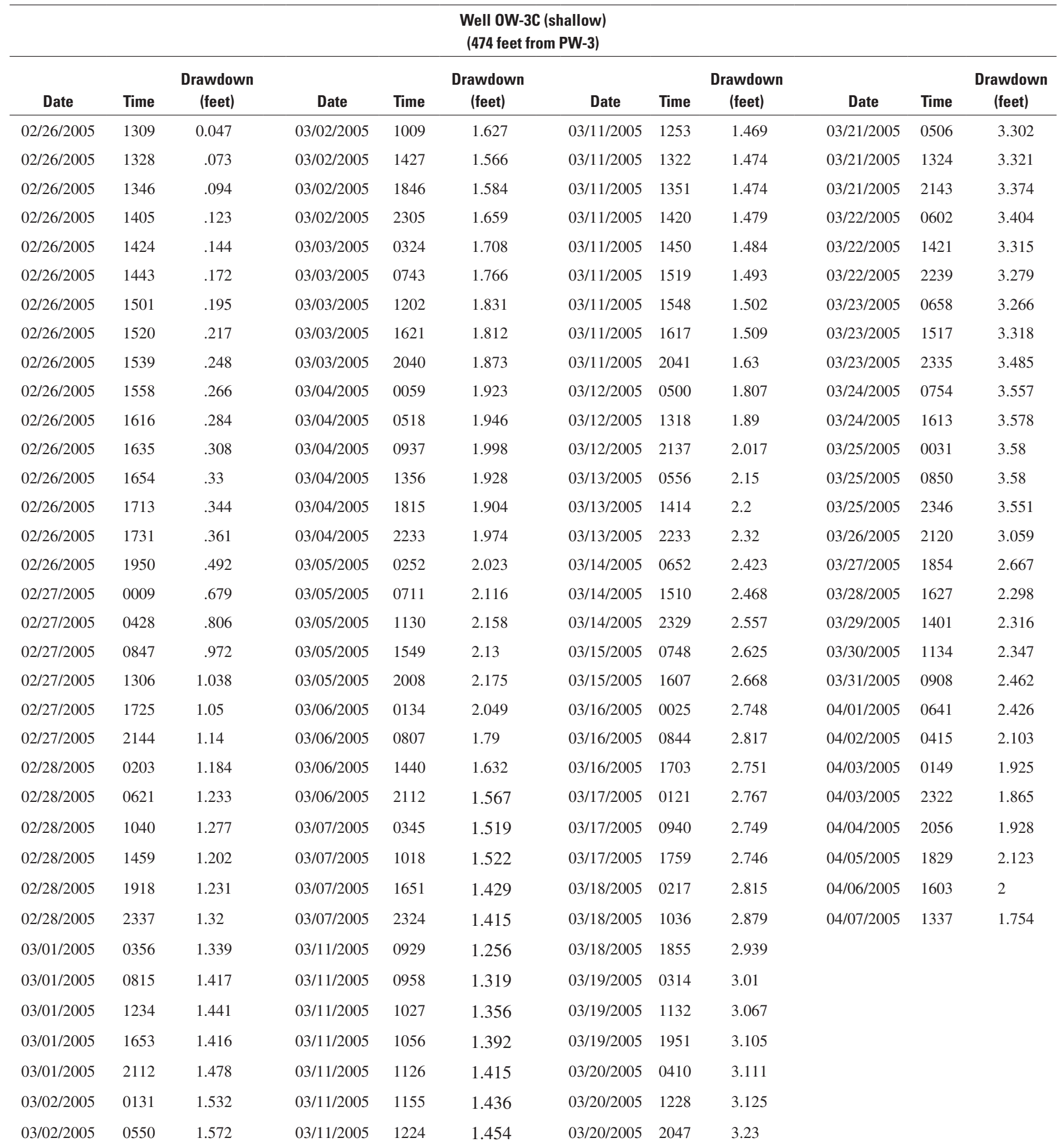




\section{Geologic, Hydrologic, and Chemical Data from the C Aquifer near Leupp, Arizona}

Table C. Filtered drawdown data for wells during constant-rate aquifer test at site 3, near Leupp, Arizona—Continued

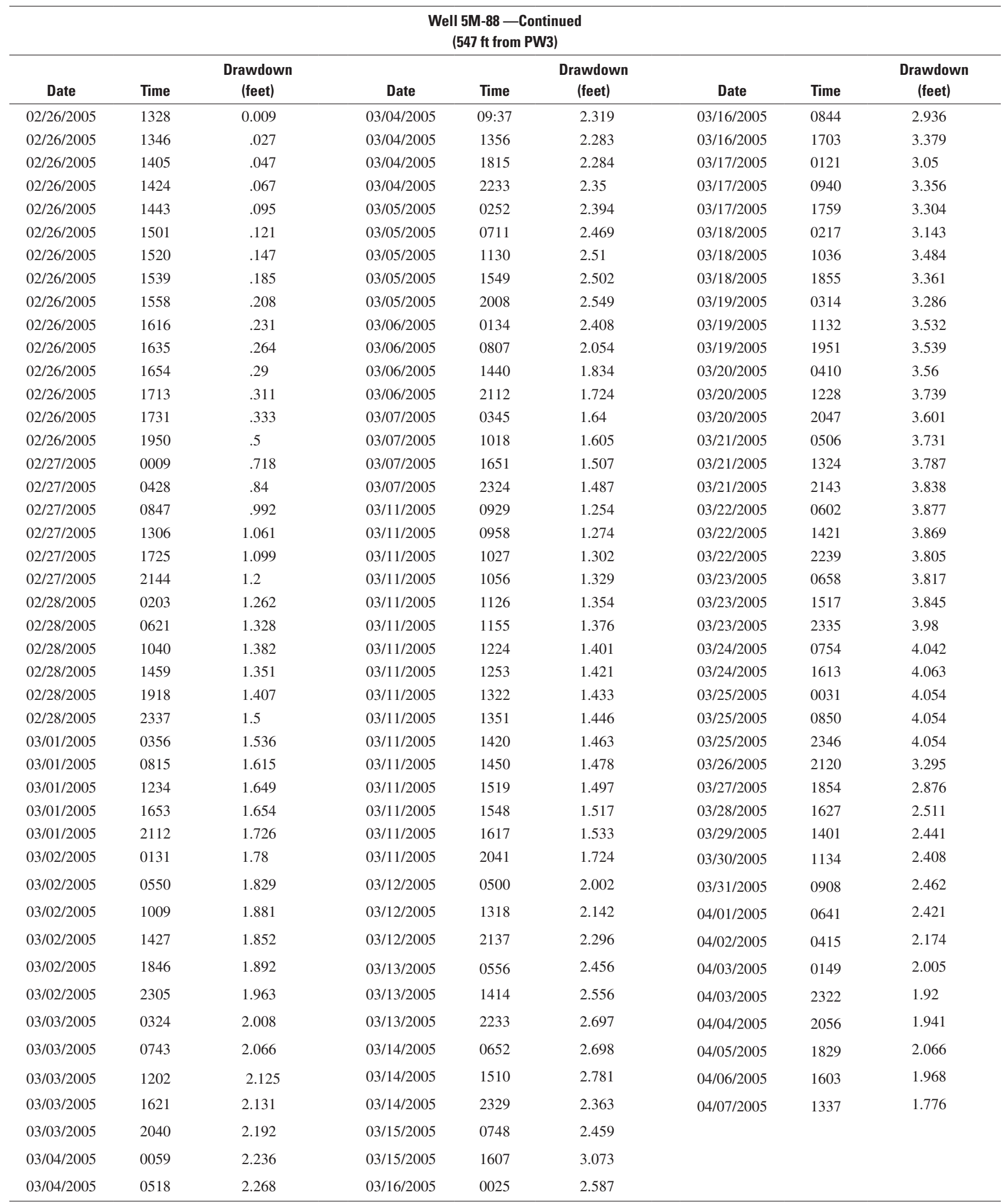


Manuscript approved for publication, 2005.

Prepared by the Reports Section, U.S. Geological Survey, Arizona Water Science Center, Tucson.

USGS Publishing staff

Steve A. Longsworth, Reports Specialist

Tracey L. Suzuki, Technical Editor

Sid Alwin, Illustrator

John Callahan, Illustrator

Aaron Fortner, Publications Assistant

For more information concerning the research in this report, contact the Arizona Water Science Center Director,

U.S. Geological Survey, 520 N. Park Ave., Suite 221

Tucson, AZ 85719

http://az.water.usgs.gov 